GLOBAL WATER PATHOGEN PROJECT

PART THREE. SPECIFIC EXCRETED PATHOGENS: ENVIRONMENTAL AND

EPIDEMIOLOGY ASPECTS

\title{
ANTIMICROBAL RESISTANCE: FECAL SANITATION STRATEGIES FOR COMBATTING A GLOBAL PUBLIC HEALTH THREAT
}

\author{
Nicholas Ashbolt \\ University of Alberta \\ Edmonton, Canada \\ Amy Pruden \\ Virginia Tech \\ Blacksburg, United States \\ Jennifer Miller \\ Virginia Tech \\ Blacksburg, United States \\ Maria V. Riquelme \\ Virginia Tech \\ Blacksburg, United States \\ Ayella Maile-Moskowitz \\ Virginia Tech \\ Blacksburg, United States
}




\section{Copyright: \\ (c) (1) () \\ BY SA}

This publication is available in Open Access under the Attribution-ShareAlike 3.0 IGO (CC-BY-SA 3.0 IGO) license (http://creativecommons.org/licenses/by-sa/3.0/igo). By using the content of this publication, the users accept to be bound by the terms of use of the UNESCO Open Access Repository (http://www.unesco.org/openaccess/terms-use-ccbysa-en).

\section{Disclaimer:}

The designations employed and the presentation of material throughout this publication do not imply the expression of any opinion whatsoever on the part of UNESCO concerning the legal status of any country, territory, city or area or of its authorities, or concerning the delimitation of its frontiers or boundaries. The ideas and opinions expressed in this publication are those of the authors; they are not necessarily those of UNESCO and do not commit the Organization.

\section{Citation:}

AshEolt, N., Pruden, A., Miller, J., Riquelme, M.V. and Maile-Moskowitz, A. 2018. AntimicroEal Resistance: Fecal Sanitation Strategies for Combatting a Global Public Health Threat. In: J.B. Rose and B. Jiménez-Cisneros, (eds) Global Water Pathogen Project. http://www.waterpathogens.org ( A. Pruden, N. Ashbolt and J. Miller (eds) Part 3 Bacteria) http://www.waterpathogens.org/book/antimicrobal-resistance-fecal-sanitation-strategies-combatting-global-public-health-threat Michigan State University, E. Lansing, MI, UNESCO.

https://doi.org/10.14321/waterpathogens.29

Acknowledgements: K.R.L. Young, Project Design editor

Website Design: Agroknow (http://www.agroknow.com)

Last published: October 19, 2018 


\section{Summary}

Over the past decades, the growing number of deaths due to antimicrobial resistant infections is beginning to rival those from traditional water, sanitation and health (WaSH) related diseases, such as diarrhea. Environmental pathways associated with water and sanitation systems are an important dimension of the global effort to control antimicrobial resistance (AMR). Yet, as discussed in other chapters, control of enteric pathogens should remain the primary focus of any sanitation system. Here, we describe the global occurrence of AMR bacteria within human and animal excreta, environmental amplification and fate of AMR bacteria within sanitation systems, and techniques for the assessment of AMR. Antibiotic resistance genes (ARGs) may be passed on and taken up by virtually all bacteria, via free DNA (transformation), bacteriophage infection (transduction) and cell-to-cell transfer (conjugation); with most acute concern when in association with infectious pathogens. No accepted AMR target for environmental monitoring is in routine use, but various promising 'AMR indicator targets' are discussed, including extendedspectrum beta-lactamase $E$. coli and an important mobile genetic element used by bacteria for ARG uptake, the class 1 integron. In general, treatment reduction of AMR follows reduction of bacterial pathogens, yet often to a lesser degree. This leads to the potential for ARGs to spread more broadly across bacterial species within environmental niches. Hence, it is important to reduce general loads of bacteria, co-selecting chemical stressors (e.g. antibiotics, biocides), ARGs, and mobile genetic elements in final products, not just pathogens, to reduce the potential uptake and spread of AMR.

\subsection{The Problem of Antimicrobial Resistance and the Role of Sanitation}

Antimicrobial resistance (AMR) is one of the greatest human health challenges of our time, and is predicted to result in more deaths than those from diarrheal illnesses within the next ten years (WHO, 2016) and may become the leading cause of death by 2050 (O'Neill, 2016a). "Antimicrobials" is a broad term encompassing any agent that kills or inhibits microbes, including bacteria, viruses, and parasites. Some antimicrobials; including heavy metals, quaternary ammonium compounds, and other sanitizers, may be used topically or for general disinfection and hygiene purposes, whereas others are formulated specifically as pharmaceuticals. "Antibiotics" are a subset of antimicrobial pharmaceuticals that specifically kill or inhibit bacteria and traditionally indicates natural compounds, although the term also commonly is meant to indicate synthetic forms as well. Antibiotics, in particular, have come to be relied upon globally as critical life-saving drugs that cure deadly bacterial infections. A wide range of classes of antibiotics have been developed and marketed since penicillin was first discovered in the 1920s, ranging from broad-spectrum antibiotics that target various classes of Gram-negative and Gram-positive bacteria, to narrowspectrum, which ideally target only the pathogen of interest. Resistance occurs when bacteria develop mutations and/or share their antibiotic resistance genes (ARGs) with other bacteria through a process called horizontal gene transfer (HGT). Bacteria that carry ARGs are better able to survive antibiotic therapy, while their non-ARG competitors are diminished. This makes antibiotic treatment a double-edged sword in which it can provide a vital cure for bacterial illnesses, while use, overuse, and misuse contributes to increasing rates of antibiotic resistance and failure of these drugs to work. Compounding the issue of AMR is that virulence factors are often associated with ARGs and transferred together via HGT (Giraud et al., 2017). Generally, antibiotic resistance has been observed to emerge in pathogenic bacteria within a few years of new antibiotics being released onto the market, with resistance rates steadily climbing. Table 1 provides key examples of bacterial pathogens and antibiotic resistance trends. Several countries and global entities, such as the World Health Organization (WHO), monitor antibiotic resistance trends in the clinical setting. A list of relevant surveillance programs and databases (as of December 2016) is provided in Table A.1.

Table 1. Examples of bacterial pathogens and current antibiotic resistance rates associated with human infections in various parts of the world (CDDEP, 2017) ${ }^{\mathrm{a}}$

\begin{tabular}{|c|c|c|c|c|c|c|c|c|}
\hline \multirow{2}{*}{$\begin{array}{l}\text { Pathogen } \\
\text { /Country }\end{array}$} & \multicolumn{8}{|c|}{ Resistant Rates (year) by antimicrobial } \\
\hline & $\mathrm{FQ}^{\mathrm{b}}$ & $\mathrm{CEPH}^{\mathrm{c}}$ & $A G^{d}$ & $\mathrm{CAR}^{\mathrm{e}}$ & VAN $^{f}$ & $\mathrm{OXA}^{\mathrm{g}}$ & $\mathrm{APh}^{\mathrm{h}}$ & $\mathrm{GEN}^{\mathrm{i}}$ \\
\hline \multicolumn{9}{|c|}{ Escherichia coli } \\
\hline Australia & $\begin{array}{c}13 \% \\
(2015)\end{array}$ & $\begin{array}{r}11 \% \\
(2015)\end{array}$ & $\begin{array}{r}8 \% \\
(2013)\end{array}$ & $\begin{array}{c}0 \% \\
(2015)\end{array}$ & NR & NR & $\begin{array}{c}55 \% \\
(2015)\end{array}$ & NR \\
\hline India & $\begin{array}{r}78 \% \\
(2015)\end{array}$ & $\begin{array}{r}78 \% \\
(2015)\end{array}$ & $\begin{array}{r}26 \% \\
(2015)\end{array}$ & $\begin{array}{c}15 \% \\
(2015)\end{array}$ & NR & NR & $\begin{array}{c}88 \% \\
(2015)\end{array}$ & NR \\
\hline $\begin{array}{l}\text { South } \\
\text { Africa }\end{array}$ & $\begin{array}{r}28 \% \\
(2016)\end{array}$ & $\begin{array}{r}23 \% \\
(2016)\end{array}$ & $\begin{array}{r}17 \% \\
(2016)\end{array}$ & $\begin{array}{c}0 \% \\
(2016)\end{array}$ & NR & NR & $\begin{array}{c}82 \% \\
(2016)\end{array}$ & NR \\
\hline UK & $\begin{array}{r}16 \% \\
(2015)\end{array}$ & $\begin{array}{r}12 \% \\
(2015)\end{array}$ & $\begin{array}{r}11 \% \\
(2015)\end{array}$ & $\begin{array}{c}0 \% \\
(2015)\end{array}$ & NR & NR & $\begin{array}{c}66 \% \\
(2015)\end{array}$ & $\begin{array}{c}10 \% \\
(2014)\end{array}$ \\
\hline USA & $\begin{array}{r}29 \% \\
(2014)\end{array}$ & $\begin{array}{r}12 \% \\
(2014)\end{array}$ & $\begin{array}{r}14 \% \\
(2012)\end{array}$ & $\begin{array}{c}1 \% \\
(2014)\end{array}$ & NR & NR & $\begin{array}{c}45 \% \\
(2012)\end{array}$ & NR \\
\hline
\end{tabular}




\begin{tabular}{|c|c|c|c|c|c|c|c|c|}
\hline \multirow{2}{*}{$\begin{array}{l}\text { Pathogen } \\
\text { /Country }\end{array}$} & \multicolumn{8}{|c|}{ Resistant Rates (year) by antimicrobial } \\
\hline & $\mathrm{FQ}^{\mathrm{b}}$ & $\mathrm{CEPH}^{\mathrm{c}}$ & $\mathrm{AG}^{\mathrm{d}}$ & $\mathrm{CAR}^{\mathrm{e}}$ & VAN $^{f}$ & $\mathrm{OXA}^{\mathrm{g}}$ & $\mathrm{AP}^{\mathrm{h}}$ & $\mathrm{GEN}^{\mathrm{i}}$ \\
\hline \multicolumn{9}{|c|}{ Klebsiella pneumonia } \\
\hline Australia & $\begin{array}{c}4 \% \\
(2015)\end{array}$ & $\begin{array}{r}6 \% \\
(2015)\end{array}$ & $\begin{array}{r}4 \% \\
(2015)\end{array}$ & $\begin{array}{c}0 \% \\
(2015)\end{array}$ & NR & NR & NR & NR \\
\hline India & $\begin{array}{r}71 \% \\
(2014)\end{array}$ & $\begin{array}{r}87 \% \\
(2014)\end{array}$ & $\begin{array}{r}63 \% \\
(2014)\end{array}$ & $\begin{array}{c}56 \% \\
(2014)\end{array}$ & NR & NR & NR & NR \\
\hline $\begin{array}{l}\text { South } \\
\text { Africa }\end{array}$ & $\begin{array}{r}36 \% \\
(2016)\end{array}$ & $\begin{array}{r}65 \% \\
(2016)\end{array}$ & $\begin{array}{r}55 \% \\
(2016)\end{array}$ & $\begin{array}{c}7 \% \\
(2016)\end{array}$ & NR & NR & NR & NR \\
\hline UK & $\begin{array}{r}14 \% \\
(2015)\end{array}$ & $\begin{array}{r}12 \% \\
(2015)\end{array}$ & $\begin{array}{r}10 \% \\
(2015)\end{array}$ & $\begin{array}{c}0 \% \\
(2015)\end{array}$ & NR & NR & NR & $\begin{array}{c}6 \% \\
(2014)\end{array}$ \\
\hline USA & $\begin{array}{r}14 \% \\
(2012)\end{array}$ & $\begin{array}{r}17 \% \\
(2014)\end{array}$ & $\begin{array}{r}11 \% \\
(2012)\end{array}$ & $\begin{array}{c}6 \% \\
(2012)\end{array}$ & NR & NR & NR & NR \\
\hline \multicolumn{9}{|c|}{ Staphylococcus aureus } \\
\hline Australia & NR & NR & NR & NR & $\begin{array}{c}0 \% \\
(2015)\end{array}$ & $\begin{array}{c}18 \% \\
(2015)\end{array}$ & NR & NR \\
\hline India & $\begin{array}{c}85 \% \\
(2014)\end{array}$ & NR & $\begin{array}{c}46 \% \\
(2012)\end{array}$ & NR & $\begin{array}{c}1 \% \\
(2015)\end{array}$ & $\begin{array}{c}39 \% \\
(2015)\end{array}$ & $\begin{array}{c}94 \% \\
(2014)\end{array}$ & NR \\
\hline $\begin{array}{l}\text { South } \\
\text { Africa }\end{array}$ & NR & NR & NR & NR & $\begin{array}{c}0 \% \\
(2014)\end{array}$ & $\begin{array}{l}27 \% \\
(2016)\end{array}$ & NR & NR \\
\hline $\mathrm{UK}$ & NR & NR & NR & NR & NR & $\begin{array}{r}11 \% \\
(2015)\end{array}$ & NR & NR \\
\hline USA & $\begin{array}{c}43 \% \\
(2012)\end{array}$ & NR & NR & NR & $\begin{array}{c}0 \% \\
(2012)\end{array}$ & $\begin{array}{c}43 \% \\
(2014)\end{array}$ & NR & NR \\
\hline \multicolumn{9}{|c|}{ Enterococcus faecalis } \\
\hline Australia & NR & NR & $\begin{array}{c}28 \% \\
(2015)\end{array}$ & $\mathrm{NR}$ & $\begin{array}{l}1 \% \\
(2015)\end{array}$ & NR & $\begin{array}{c}0 \% \\
(2015)\end{array}$ & NR \\
\hline India & $89 \%$ & NR & NR & NR & $\begin{array}{c}7 \% \\
(2015)\end{array}$ & NR & $\begin{array}{c}49 \% \\
(2015)\end{array}$ & NR \\
\hline $\begin{array}{l}\text { South } \\
\text { Africa }\end{array}$ & NR & NR & $\begin{array}{c}50 \% \\
(2014)\end{array}$ & NR & $\begin{array}{c}1 \% \\
(2016)\end{array}$ & NR & $\begin{array}{c}12 \% \\
(2016)\end{array}$ & $\begin{array}{c}74 \% \\
(2014)\end{array}$ \\
\hline UK & NR & NR & $\begin{array}{c}31 \% \\
(2013)\end{array}$ & NR & $\begin{array}{c}4 \% \\
(2015)\end{array}$ & NR & $\begin{array}{c}35 \% \\
(2014)\end{array}$ & $\begin{array}{r}55 \% \\
(2013)\end{array}$ \\
\hline USA & NR & NR & $\begin{array}{c}34 \% \\
(2012)\end{array}$ & NR & $\begin{array}{c}6 \% \\
(2014)\end{array}$ & NR & $\begin{array}{c}1 \% \\
(2012)\end{array}$ & $\begin{array}{c}13 \% \\
(2012)\end{array}$ \\
\hline \multicolumn{9}{|c|}{ Enterococcus faecium } \\
\hline Australia & NR & NR & $\begin{array}{c}59 \% \\
(2015)\end{array}$ & NR & $\begin{array}{c}50 \% \\
(2015)\end{array}$ & NR & $\begin{array}{c}87 \% \\
(2015)\end{array}$ & NR \\
\hline India & $\begin{array}{c}97 \% \\
(2014)\end{array}$ & NR & NR & NR & $\begin{array}{c}30 \% \\
(2015)\end{array}$ & NR & $\begin{array}{c}87 \% \\
(2015)\end{array}$ & $\begin{array}{r}79 \% \\
(2014)\end{array}$ \\
\hline $\begin{array}{l}\text { South } \\
\text { Africa }\end{array}$ & NR & NR & $\begin{array}{r}74 \% \\
(2014)\end{array}$ & NR & $\begin{array}{c}5 \% \\
(2016)\end{array}$ & NR & $\begin{array}{c}96 \% \\
(2016)\end{array}$ & $\begin{array}{r}50 \% \\
(2014)\end{array}$ \\
\hline UK & NR & NR & $\begin{array}{c}55 \% \\
(2013)\end{array}$ & NR & $\begin{array}{c}17 \% \\
(2015)\end{array}$ & NR & $\begin{array}{c}82 \% \\
(2014)\end{array}$ & $\begin{array}{r}31 \% \\
(2013)\end{array}$ \\
\hline USA & NR & NR & $\begin{array}{c}13 \% \\
(2012)\end{array}$ & NR & $\begin{array}{c}78 \% \\
(2014)\end{array}$ & NR & $\begin{array}{l}87 \% \\
(2012)\end{array}$ & $\begin{array}{r}34 \% \\
(2012)\end{array}$ \\
\hline
\end{tabular}

${ }^{a}$ Table 1 data are drawn from ResistanceMap, a tracking tool developed by Center for Disease Dynamics, Economics, and Policy (CDDEP) that summarizes clinical data from multiple global surveillance databases to inform on resistance trends (CDDEP, 2017). ${ }^{b} \mathrm{FQ}$ - Fluoroquinolones; ${ }^{\mathrm{c}} \mathrm{CEPH}$ - Cephalosporins; ${ }^{\mathrm{d}} \mathrm{AG}$ - Aminoglycocide; ${ }^{\mathrm{e}} \mathrm{CAR}$ - Carbapenems; ${ }^{\mathrm{f}} \mathrm{VAN}$ Vancomycin; ${ }^{9}$ OXA- Oxacillin; ${ }^{\mathrm{h}} \mathrm{AP}$ - Aminopenicillins; ${ }^{\mathrm{i}} \mathrm{GEN}$ - Gentamycin; NR- not reported.

\subsection{Global Distribution of Antibiotic Resistance Genes (ARGs)}

To date, there is no global surveillance database for monitoring trends in environmental ARGs. This is, in part, the result of the constant stream of newly discovered genes, but also reflects the inability to conduct molecular analyses in many areas of the world. There are, however, numerous reviews and case studies reporting ARG incidence within clinical isolates (e.g., (Poirel et al., 2005; 
Kazmierczak et al., 2016). For example, Kazmierczak et al. (2016) reported on a global survey of metallo-betalactamase (MBL)-encoding genes among carbapenemresistant bacteria isolated from clinical samples from 40 countries (2012-2014). The distribution of NDM-, VIM-, IMP-, SPM-type MBL enzymes was $44.2 \%$, 39.3\%, 16.5\%, and $0 \%$ among MBL-positive Enterobacteriaceae. In contrast, the distribution of NDM-, VIM-, IMP-, SPM-type MBL enzymes was $1.0 \%, 87.7 \%, 11.3 \%$, and $0 \%$ among MBL-positive Pseudomonas aeruginosa. The authors report geographic variations in prevalence as well, with NDMtypes more common in the Balkans, Middle East, and Africa; VIM-types more common in Europe and Latin America; and, IMP-types more common in Asia-Pacific. To date, no MBL-positive isolates have been detected in Ireland, Denmark, Netherlands, Sweden, or Israel. Given the rapidly changing scene in AMR detected in various countries, Table 1 simply provides a snapshot of antibiotic resistance rates associated with human infections across a range of regions. Overall, there is a growing pattern of novel AMR pathogens first reported in a single country, with varying rates (rapid or slow) of transfer by human/food carriers to other parts of the world. With respect to environmental surveillance, the WHO, EU, and selected countries in Asia and Africa have initiated a pilot program that targets extended-spectrum beta lactamase (ESBL)producing Escherichia coli screened from routinely cultured E. coli identified in water quality studies (Matheu et al., 2017).

The rise of antibiotic resistance has become a wellrecognized global public health threat, with several countries and international bodies beginning to maintain surveillance databases (Table A1) and develop strategies for combatting its spread (WHO, 2014; Office of the President, 2015; O'Neill, 2016b). In particular, global organizations, such as the WHO, have emphasized the need for concerted and coordinated efforts aimed at surveillance that include environmental pathways (WHO, 2015). Such surveillance can aid in our understanding of the main causes of resistance and identify management options to limit its spread across international borders, particularly via travel, import/export of food products, and movement of people and their excreta. Of particular concern are sublethal doses given to humans and animals that select for resistant strains (Andersson and Hughes, 2014) and residual antimicrobials and ARGs that are released into the environment (Grenni et al., 2018). Hence, the European Union has taken one key step by banning the use of antibiotics in livestock for purposes other than direct disease treatment, though it is clear that such bans alone will not stop the spread of antibiotic resistance (Kalmokoff et al., 2011; Marshall and Levy, 2011; Massow and Ebner, 2013; Bondarczuk et al., 2016; Di Cesare et al., 2016). In particular, enforcement of policy, offering viable alternatives to antibiotics, and identifying practices to prevent livestock illness in the first place are key to reducing antimicrobial use. Here we emphasize the need to consider strategies to contain the spread of AMR that are synergistic with other general environmental and pathogen reduction benefits when developing and implementing sanitation technologies, which in many regions may also include animal manures.

\subsection{Types of ARGs of Concern}

Tables 2 to 5 summarize ARGs of clinical concern to last-resort antibiotics; however, the evolution of antibiotic resistance is dynamic and this list is by no means exhaustive. The advantage of targeting these genes is that as they may raise a red flag of direct concern to human health, as treatment failure is more likely when pathogens carry these types of resistance. Overall, each of the ARGs corresponding to the WHO (2017) list of AMR bacteria of medium to high concern have been reported in human/animal excreta. Therefore, the environmental release of these genes may provide an effective pathway of transmission unless adequate sanitary management is in place (see Table 4 for a summary of treatment efficacies).

Table 2. Clinically-relevant ARGs corresponding to last-resort antibiotics and possible targets associated with sanitation systems and animal excreta

\begin{tabular}{|c|c|c|c|c|}
\hline Antibiotic & ARG/ target & Gene Target & Location & $\begin{array}{c}\text { Associated } \\
\text { bacteria/pathogen }\end{array}$ \\
\hline \multicolumn{5}{|c|}{ Clinically-relevant } \\
\hline Cephalosporin & ampC & $\begin{array}{l}\text { Encode beta lactamase } \\
\text { enzymes that hydrolyze } \\
\text { and break the beta } \\
\text { lactam ring structure }\end{array}$ & $\begin{array}{l}\text { Transmissible } \\
\text { plasmids } \\
\text { Chromosomal }\end{array}$ & $\begin{array}{c}\text { Escherichia coli, } \\
\text { Klebsiella pneumoniae; } \\
\text { Acinetobacter baumannii } \\
\text { Enterobacteriaceae }\end{array}$ \\
\hline Methicillin & mecA & $\begin{array}{l}\text { Encodes the low-affinity } \\
\text { penicillin-binding protein } \\
\text { PBP 2A, which allows } \\
\text { continued cell wall } \\
\text { synthesis by } \\
\text { transpeptidases }\end{array}$ & $\begin{array}{l}\text { chromosomal } \\
\text { SCCmec mobile } \\
\text { genetic element }\end{array}$ & Staphylococcus aureus \\
\hline
\end{tabular}




\begin{tabular}{|c|c|c|c|c|}
\hline Antibiotic & ARG/ target & Gene Target & Location & $\begin{array}{c}\text { Associated } \\
\text { bacteria/pathogen }\end{array}$ \\
\hline $\begin{array}{l}\text { Extended spectrum } \\
\text { beta lactamase (ESBL) }\end{array}$ & $\begin{array}{c}C T X, T E M, S H V, a m p C, \\
O X A\end{array}$ & $\begin{array}{l}\text { Encode beta-lactamase } \\
\text { enzymes that hydrolyze } \\
\text { extended-spectrum } \\
\text { cephalosporins with an } \\
\text { oxyimino side chain. }\end{array}$ & Plasmid & Enterobacteriaceae \\
\hline $\begin{array}{l}\text { Carbapenem-resistant } \\
\text { beta lactamase }\end{array}$ & $K P C, S I M$ & $\begin{array}{c}\text { Encode beta lactamase } \\
\text { enzymes that hydrolyze } \\
\text { carbapenems }\end{array}$ & $\begin{array}{l}\text { Plasmid, } \\
\text { chromosome }\end{array}$ & $\begin{array}{c}\text { Pseudomonas aeruginosa } \\
\text { and Acinetobacter spp.; } \\
\text { Enterobacteriaceae }\end{array}$ \\
\hline Metallo-beta lactamase & $\begin{array}{c}\text { NDM (New Delhi Metallo- } \\
\text { beta-lactamase), IMP } \\
\text { VIM, SPM }\end{array}$ & $\begin{array}{c}\text { Encode beta-lactamase } \\
\text { enzymes called } \\
\text { carbapenemases }\end{array}$ & $\begin{array}{c}\text { Plasmid, } \\
\text { chromosome } \\
\text { (stability varies) }\end{array}$ & $\begin{array}{c}\text { Enterobacteriaceae, } \\
\text { Acinetobacter baumannii, } \\
\text { Shigella boydii, Vibrio } \\
\text { cholerae, Aeromonas } \\
\text { caviae, Klebsiella } \\
\text { pneumoniae, and } \\
\text { Escherichia coli }\end{array}$ \\
\hline $\begin{array}{l}\text { Polymyxin (bacitracin, } \\
\text { colistin) }\end{array}$ & $m c r-1, p m r A B$ & Target modification & Plasmid (mcr-1) & $\begin{array}{l}\text { Pseudomonas aeruginosa, } \\
\text { Acinetobacter baumannii, } \\
\text { Klebsiella pneumoniae, } \\
\text { and Escherichia coli }\end{array}$ \\
\hline Macrolides & erm, msr & & $\begin{array}{l}\text { Chromosome } \\
\text { plasmid }\end{array}$ & \\
\hline Aminoglysides & aac, npm, rmt, arm & $\begin{array}{l}\text { bacterial rRNA } \\
\text { methylation, defect of } \\
\text { cellular permeability, } \\
\text { and active efflux pumps }\end{array}$ & $\begin{array}{l}\text { Chromosome } \\
\text { plasmid } \\
\text { transposon }\end{array}$ & $\begin{array}{l}\text { Broad range, Gram- } \\
\text { negative and Gram- } \\
\text { positive bacteria }\end{array}$ \\
\hline Quinolone & $q n r, g y r, a a c\left(6^{\prime}\right)-\mathrm{Ib}-\mathrm{cr}$, & $\begin{array}{c}\text { DNA gyrase } \\
\text { and efflux pumps }\end{array}$ & $\begin{array}{l}\text { Chromosome } \\
\text { plasmid }\end{array}$ & $\begin{array}{c}\text { Acinetobacter baumannii, } \\
\text { Aeromonas, Citrobacter, } \\
\text { Shewanella spp., and } \\
\text { Enterobacteriaceae ( } E . \\
\text { coli, Salmonella) }\end{array}$ \\
\hline Vancomycin & vanA, B, C & $\begin{array}{c}\text { Encodes peptidoglycan } \\
\text { precursors (involved in } \\
\text { cell wall synthesis) with } \\
\text { low affinity for binding } \\
\text { vancomycin }\end{array}$ & $\begin{array}{l}\text { Chromosome } \\
\text { plasmid }\end{array}$ & $\begin{array}{c}\text { Enterococcus faecalis, } \\
\text { Enterococcus faecium, } \\
\text { and Staphylococcus } \\
\text { aureus }\end{array}$ \\
\hline
\end{tabular}

Table 3. Possible indicators of ARGs for sanitation systems and in agriculture

\begin{tabular}{|c|c|c|c|c|c|}
\hline Antibiotic & $\begin{array}{c}\text { ARG/ } \\
\text { target }\end{array}$ & $\begin{array}{c}\text { Gene } \\
\text { Target }\end{array}$ & Location & $\begin{array}{c}\text { Associated } \\
\text { bacteria/pathogen }\end{array}$ & Reference \\
\hline \multicolumn{6}{|c|}{ Possible indicator ARGs for sanitation systems and in agriculture } \\
\hline tetracyclines & tet & Various & $\begin{array}{l}\text { Chromosome } \\
\text { plasmid }\end{array}$ & & $\begin{array}{c}\text { Chee-Sanford et al., } \\
\text { 2009; Borjesson et al., } \\
\text { 2010; McKinney et al., } \\
\text { 2010; Storteboom et al., } 2010\end{array}$ \\
\hline sulfonamide & sul & & $\begin{array}{l}\text { Chromosome } \\
\text { plasmid }\end{array}$ & & Vaz-Moreira et al., 2016 \\
\hline erythromycin & erm & & $\begin{array}{l}\text { Chromosome } \\
\text { plasmid }\end{array}$ & & Ben Said et al., 2015 \\
\hline
\end{tabular}


Table 4. Possible aquaculture ARG indicators

\begin{tabular}{|c|c|c|c|c|c|}
\hline Antibiotic & ARG/ target & Gene Target & Location & $\begin{array}{c}\text { Associated } \\
\text { bacteria/pathogen }\end{array}$ & Reference \\
\hline \multicolumn{6}{|c|}{ Aquaculture Indicator ARGs } \\
\hline $\begin{array}{l}\text { Tetracycline } \\
\text { (most } \\
\text { common) }\end{array}$ & $\begin{array}{c}\text { TetA, B, D, E, G, } \\
\text { H, L, M, O, Q, } \\
\text { S, W, 34, } 35\end{array}$ & $\begin{array}{l}\text { proton-dependent } \\
\text { efflux pumps or via } \\
\text { ribosomal protection }\end{array}$ & $\begin{array}{l}\text { Tn1721, Tn5706, } \\
\text { transposons, mobile } \\
\text { plasmids, integrons } \\
\text { (Class } 1,2,3)\end{array}$ & $\begin{array}{c}\text { Aeromonas, Clostridium, } \\
\text { Edwardsiella, } \\
\text { Salmonella, Vibrio spp., } \\
\text { Listeria monocytogenes, } \\
\text { and E. coli }\end{array}$ & $\begin{array}{c}\text { Jacobs and } \\
\text { Chenia, } \\
\text { 2007; Miranda et } \\
\text { al., 2013; Done } \\
\text { and Halden, 2015 }\end{array}$ \\
\hline Quinolones & $\begin{array}{l}\text { qnrA,B,D,S } \\
\text { aac(6')-lb-cr, } \\
\text { aac(69)-lb-cr, } \\
\text { qepA, oqxAB } \\
\text { efflux pumps }\end{array}$ & $\begin{array}{l}\text { DNA gyrase and } \\
\text { topoisomerase IV }\end{array}$ & plasmids & $\begin{array}{c}\text { Aeromonas, } \\
\text { Edwardsiella, } \\
\text { Photobacterium, Vibrio } \\
\text { spp., and E. coli, }\end{array}$ & $\begin{array}{l}\text { Miranda et al., } \\
2013\end{array}$ \\
\hline Phenicols & floR & $\begin{array}{l}\text { Encodes efflux } \\
\text { protein for } \\
\text { florfenicol }\end{array}$ & IncA/C plasmid & $\begin{array}{c}\text { Aeromonas, } \\
\text { and Edwardsiella spp. }\end{array}$ & $\begin{array}{l}\text { Miranda et al., } \\
2013\end{array}$ \\
\hline Sulfonamides & sul1, sul2 & & $\begin{array}{l}\text { Plasmids, integrons } \\
\text { (Class } 1)\end{array}$ & $\begin{array}{c}\text { Acinetobacter, } \\
\text { Enterobacteriaceae, } \\
\text { and Bacillus spp. }\end{array}$ & $\begin{array}{c}\text { Jacobs and } \\
\text { Chenia, } \\
\text { 2007; Miranda et } \\
\text { al., 2013; Done } \\
\text { and Halden, } 2015\end{array}$ \\
\hline
\end{tabular}

Table 5. Indicators of gene capture, mobility, and horizontal transfer of ARGs

\begin{tabular}{|c|c|c|c|c|c|}
\hline Antibiotic & $\begin{array}{c}\text { ARG/ } \\
\text { target }\end{array}$ & Gene Target & Location & Associated bacteria/pathogen & Reference \\
\hline \multicolumn{6}{|c|}{ Horizontal Gene Transfer } \\
\hline Class 1 integron & intI1 & integrase enzyme & $\begin{array}{l}\text { Chromosome } \\
\text { plasmid }\end{array}$ & $\begin{array}{c}\text { Associated with resistance genes } \\
\text { for fluoroquinolones, } \\
\text { trimethoprim/sulfamethoxazole, } \\
\text { amoxicillin/clavulanate, } \\
\text { piperacillin/tazobactam in many } \\
\text { genera, and multidrug-resistance } E \text {. } \\
\text { coli }\end{array}$ & $\begin{array}{l}\text { Kotlarska et al., } \\
\text { 2015; Aubertheau } \\
\text { et al., } 2017\end{array}$ \\
\hline $\begin{array}{l}\text { Incompatibility } \\
\text { plasmid }\end{array}$ & incI1, incl2 & $\begin{array}{l}\text { Typically carry } \\
\text { multiple ARGs }\end{array}$ & plasmids & Enterobacteriaceae & $\begin{array}{c}\text { Dropa et al., } \\
\text { 2016; Ovejero et al., } \\
2017\end{array}$ \\
\hline transposons & transposon & $\begin{array}{c}\text { contain } \\
\text { integrons-more } \\
\text { complex } \\
\text { transposons } \\
\text { contain a site for } \\
\text { integrating } \\
\text { different ARGs and } \\
\text { other gene } \\
\text { cassettes in } \\
\text { tandem for } \\
\text { expression from a } \\
\text { single promoter }\end{array}$ & $\begin{array}{l}\text { Chromosome } \\
\text { plasmid } \\
\text { Naked DNA }\end{array}$ & $\begin{array}{c}\text { Gram-positive and Gram-negative } \\
\text { bacteria }\end{array}$ & $\begin{array}{l}\text { Levy and Marshall, } \\
\qquad 2004\end{array}$ \\
\hline $\begin{array}{l}\text { Broad host range } \\
\text { plasmids }\end{array}$ & $\begin{array}{l}\text { Wide range } \\
\text { ARG }\end{array}$ & multiple & plasmid & Wide range of bacteria & $\begin{array}{l}\text { Akiyama et al., } \\
\text { 2010; Jain and } \\
\text { Srivastava, } 2013\end{array}$ \\
\hline
\end{tabular}




\subsection{Transmission of ARGs}

Sanitation is a logical critical control point to aid in reducing the spread of antibiotic resistance. Human and animal waste-streams contain antibiotic resistant bacteria (ARBs), ARGs, antibiotics, metals, and other potential agents that could exert selection pressure for AMR. Depending on how the waste is treated and handled, resistance levels can increase or decrease (Marti et al., 2013; Larson, 2015; Bengtsson-Palme et al., 2016; Bondarczuk et al., 2016; Holman et al., 2016; Qian et al., 2016). Ideally, sanitation technologies can be adapted to serve their intended purpose of minimizing human exposure to fecal pathogens, while also reducing the potential spread of ARGs to human pathogens or to the reservoir of resistance in the natural human, aquatic, and soil microbiomes. However, in order to synergistically achieve these goals, it is critical to understand the nature of risk posed by antibiotic resistance and how it differs from pathogens and fecal indicators that have traditionally served as treatment targets.

Figure 1 illustrates how fecal contamination pathways in the environment may also serve as dissemination routes for the spread of AMR. The spread of AMR is distinct, however, as the DNA that confers resistance (i.e., ARGs) can be spread among different (including non-pathogenic) species of bacteria by HGT mechanisms, including conjugation (mating between bacteria) and transduction (via bacteriophage infection). ARGs from dead organisms, existing as free DNA in the environment, may also be assimilated by downstream bacteria by a process called transformation-hence disinfection of excreta alone may not be totally effective at preventing the spread of AMR. Also, natural and engineered stressors (such as disinfectants and disinfection by-products (Zhang et al., 2017) can induce mutations and select for biocide resistance and co-select for ARB leading to AMR (Baharoglu et al., 2013; Culyba et al., 2015). Sanitation technologies should ideally aim to reduce the conditions for selection and HGT (including to clinical strains) of ARGs and to physically destroy ARGs where possible (Bouki et al., 2013; Al-Jassim et al., 2015; BengtssonPalme et al., 2016). Mixing pathogenic bacteria within environments containing high densities of active bacteria and in the presence of selective and stress agents, such as antibiotics and metals, may increase the potential for horizontal transfer of ARGs (Abraham, 2011; Andam and Gogarten, 2011). Mixing of waste streams with high concentrations of antibiotics, such as from pharmaceutical manufacturing facilities or feedlot manures where sub-therapeutic concentrations of antimicrobials are used, with those containing human pathogens, such as domestic waste, is not recommended (Sidrach-Cardona et al., 2014). Segregated treatment of hospital waste has also been suggested as a "hot spot" control strategy (Rodriguez-Mozaz et al., 2015).

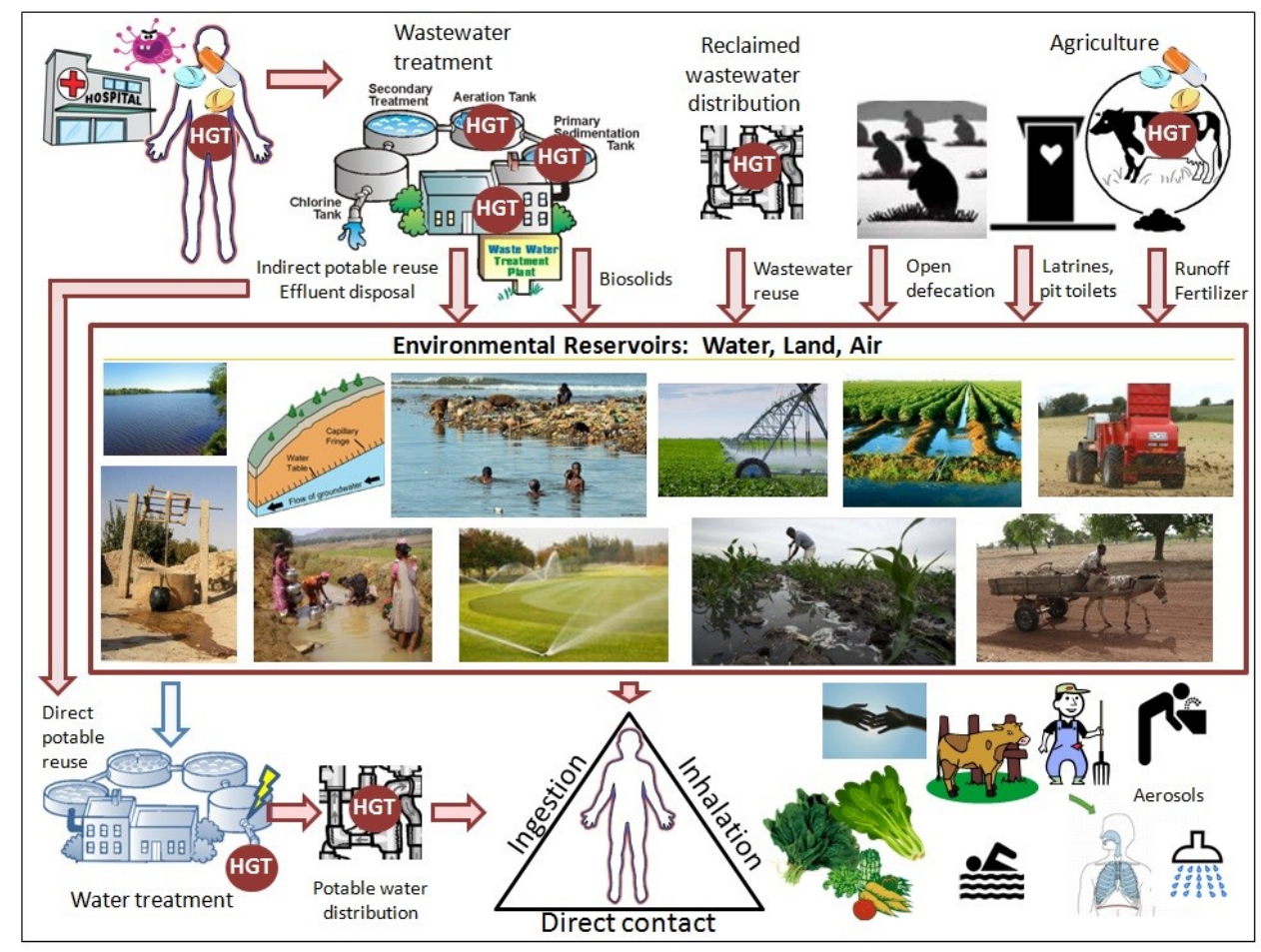

Figure 1. Environmental pathways of AMR showing sanitation as critical control points (red arrows) for dissemination of

ARBs and ARGs. Also highlighted are likely hotspots for horizontal gene transfer (HGT). Environmental reservoirs include drinking water sources (groundwater, shallow wells, surface water), recreation/bathing water sources, irrigation (crop, turf), and biosolid/compost/manure storage or land application 


\subsection{Risk assessment for AMR}

An important avenue for focused scientific effort is in the development of human health risk assessment models specifically tailored to antibiotic resistance. Microbial risk assessment, including quantitative microbial risk assessment (QMRA), serves to estimate the probability of human infection, given a defined exposure dose and exposure route(s) (Ashbolt et al., 2013). However, new models are needed that consider HGT and the fact that resistant infection following exposure may not be immediate. For example, elevating resistance levels among non-pathogenic environmental bacteria (e.g., through ineffective sanitation measures or those using high microbial activity) could increase the probability of transferring ARGs to native bacteria and human pathogens in the environment (especially if waste streams are mixed) or potentially to pathogens on human skin or within the gut microbiota itself. The ultimate "risk" then is defined not just as an infection itself, but as failure of antibiotics to cure an infection, or "treatment failure".

Developing risk models with the goal of informing the management of antimicrobial resistance will take time and will require elements of dynamic disease transmission modeling not traditionally used in QMRA. Thus, we are wise to proceed in parallel with the advancement of mitigation technologies that conservatively target both pathogen and ARG reduction and ideally are low-cost and work within the framework of existing sanitation goals (Pruden et al., 2013).

\subsection{Environmental Occurrence and Persistence}

Environmental and clinical reservoirs of resistance are linked and employ conditions that exert selection pressure, or that are conducive to HGT and exacerbate the spread of antibiotic resistance. A significant body of scientific literature has grown in the last decade, documenting how human activities along with animal manure management can serve to increase background levels of resistance in soil and water environments (Singer et al., 2006; Cantas et al., 2013; Rizzo et al., 2013b; Blaak et al., 2015a; Sharma et al., 2016; Singer et al., 2016; Zhu et al., 2017). Together, there is substantial evidence that environmental routes of resistance dissemination can contribute to evolution of resistant pathogens that ultimately appear in clinics and hospitals (Taylor et al., 2011; Hölzel et al., 2012; Ma et al., 2016a).

In practice, it can (fortunately) be difficult to detect clinically-relevant genes in environmental matrices, which can make them poor targets for certain applications, such as assessing the likely benefits of various sanitation technologies for mitigating the spread of ARGs (Table 2). For this reason, more commonly detected genes in the environment, such as the sulfonamide and tetracycline
ARGs, are popular among researchers (Bengtsson-Palme et al., 2016; Pei et al., 2016). While resistance to these antibiotics is rarely a serious clinical concern because their corresponding resistance determinants have become widespread, they can provide informative targets for predicting how ARGs may respond to treatments or behave in the environment. For example, Pruden et al. (2012) reported a near perfect correlation between the sul1 sulfonamide ARG and upstream densities of livestock operations and wastewater treatment plants. Therefore, such commonly occurring genes may serve as "AMR indicator genes". HGT markers or determinants (Table 5), are not technically ARGs, but are considered to be indicative of the potential for ARGs to be transferred among bacteria, which is arguably the ultimate concern (Gillings, 2014; Culyba et al., 2015; Sharma et al., 2016). If ARGs stay confined within a non-pathogenic host, then this is not as much of a concern as if they are transferred, or have the potential to be transferred, to a pathogen. Targets include gene markers for plasmids, particularly the highly transferrable plasmids such as those within certain incompatibility "inc" groups, integrons, transposons and other mobile genetic elements, all of which have been noted in some cases to carry several ARGs (Chang et al., 2016; Folster et al., 2016; Saito et al., 2016).

Recently it was reported that, similarly to sul1, the intI1 gene encoding class 1 integrase is a strong indicator of "pollution" (Gillings et al., 2015), including resistance to fluoroquinolones, trimethoprim/sulfamethoxazole, amoxicillin/clavulanate, piperacillin/tazobactam, and presence of multidrug-resistance E. coli (Kotlarska et al., 2015). Also, the European COST Action group recommended a strategy of monitoring a mixture of clinical ARGs, indicator ARGs, and gene transfer markers, and an international cross-comparative study led by the NORMAN network that is currently underway (Berendonk et al., 2015; COST, 2017; NORMAN, 2017).

\subsection{Detection Methods for Antibiotic Resistance Monitoring Targets}

Special consideration is needed for the monitoring of antibiotic resistance, particularly for assessing the effectiveness of sanitation technologies and tracking any significant change in the spread of resistance via environmental routes. Monitoring methods largely fall into two classes: 1) culture-based methods and 2) molecular methods. The pros and cons of these methods for tracking antibiotic resistance in the environment have been extensively reviewed (Luby et al., 2016; McLain et al., 2016). Here we provide a brief overview and highlight some key points in the context of local sanitation systems.

When monitoring for AMR it is critical to recognize that, just as antibiotics are largely natural or naturally-derived compounds, there is a ubiquitous background level of 
antibiotic resistance for certain ARGs (Rothrock et al., 2016). Microbes have evolved the ability to both produce antibiotics (e.g., to ward off competitors), as well as the ability to resist antibiotics (Davies, 2006; Martinez, 2008; Forsberg et al., 2012; Culyba et al., 2015; Westhoff et al., 2017). While it is true that antimicrobial resistance is a natural phenomenon, what has changed in the modern era are the sheer concentrations and loadings of antibiotics and other selective agents to which microbes are being exposed. Elevated levels of antibiotics are a direct result of mass industrial production, use in humans, companion animals and livestock, and corresponding release and excretion into the environment. Thus, ideally, culture-based and molecular-based monitoring technologies are designed to identify changes in the kinds and levels of these resistance indicators against a relevant background.

In terms of culture-based techniques, some consensus is emerging around $E$. coli as a highly suitable target (Blaak et al., 2015b; Liang et al., 2015), although many other potentially useful bacterial targets, such as Klebsiella spp. (Berendonk et al., 2015), fecal enterococci (Berendonk et al., 2015), and bacteria that grow in aquatic/soil environments such as Pseudomonas aeruginosa (Santoro et al., 2015) or various Aeromonads (Varela et al., 2016) exist. However, E. coli is a practical choice given that it is already the most widely monitored target as an indicator of fecal pollution and thus methodologies are already standardized and infrastructure is more likely to be in place to implement monitoring campaigns based on E. coli (Matheu et al., 2017).

Minimum inhibitory concentrations (MICs) for most antibiotics are largely defined for susceptible E. coli, making it relatively straightforward to either incorporate antibiotics into E. coli selective media, or perform MIC breakpoint assays on isolated bacteria. The latter can be accomplished in 96 well trays using the Kirby-Bauer disk diffusion assay (Bauer et al., 1966; CLSI, 2015). This enables assessment of antibiotic resistance under defined conditions: using a viable strain phenotypically expressing resistance in a manner that can be directly compared to known MICs. Further advantages are that E. coli is generally a fecal-associated organism (thus maintaining relevance to tracking fecally-derived sources of antibiotic resistance) (Ashbolt et al., 2001). Importantly, some E. coli strains are known pathogens and many strains are also known to be capable of receiving and transferring genes within or between species (Kotlarska et al., 2015).

There are numerous resistant pathogens of major global concern (WHO, 2017), several of them summarized in Table 1 ; it is unknown to what extent the behavior of resistant $E$. coli is representative of other resistant pathogens, particularly those that grow well in water/sanitation environments, such as Aeromonas spp., Arcobacter spp., and $P$. aeruginosa. A further general downside of culturebased techniques is that they will not provide information about the broader microbial ecological behavior of ARGs, given that environmental samples will typically contain billions of microbes and their mobile genetic elements, with culture-based techniques capturing only a small fraction. Methods such as heterotrophic plate counts incorporating antibiotics into their culture media can provide insight into the behavior of broader groups of bacteria than groupselective media, but still will capture only culturable bacteria, a tiny fraction of the true bacterial community (Bartram et al., 2004). All will suffer from not knowing the identities of the isolated bacteria and thus not being able to differentiate acquired resistance from intrinsic resistance (Cox and Wright, 2013; e.g., a Gram-positive organism growing in the presence of an antibiotic targeting Gramnegatives is "intrinsically resistant"). Also, culture-based methods are generally extremely laborious and timeconsuming and thus not ideally suited for extensive monitoring or certain research applications.

Molecular-based methods present the advantage of directly targeting ARGs as the presumptive agents of resistance while also circumventing biases associated with culture-based techniques. However, the simple presence of a gene does not mean it is functional or capable of being expressed. ARGs can be transferred horizontally, thus transcending their bacterial hosts. Further, given that they strongly correlate with anthropogenic inputs (Gaze et al., 2011; Pruden et al., 2013; Rizzo et al., 2013b; Ahammad et al., 2014; Graham et al., 2014; Singer et al., 2016), ARGs have been described as "pollutants" in their own right (Pruden et al., 2006). In Table 6 several available molecular methods for antibiotic resistance monitoring are summarized. Just as there are tens of thousands of species of bacteria in an environmental sample, there appears to be thousands of different types of detectable ARGs. A potential problem in only targeting ARGs via molecular methods is that such genes may not be expressed and/or passed on to pathogens of concern. Expression in cultured isolates provides more definitive information on functionality of ARGs within a viable host (Wichmann et al., 2014; Ma et al., 2016a; Bengtsson-Palme et al., 2017; Surette and Wright, 2017; Zhu et al., 2017). This brings to question, which ARGs and/or mobile genetic elements to monitor?

As indicated in Table 6, there are several available methods including qPCR and numerous other assays which are used for ARG targets. In general, there are three categories of relevant gene targets: 1) ARGs of direct clinical concern; 2) indicator ARGs; and 3) determinants for gene mobilization. ARGs of clinical concern include those encoding resistance to last-resort antibiotics, such as vancomycin, carbapenems or colistins (Hocquet et al., 2016; Mediavilla et al., 2016; Sharma et al., 2016; EFSA, 2017; Al-Tawfig et al., 2017). 
Table 6. Molecular methods for antimicrobial resistance monitoring

\begin{tabular}{|c|c|c|c|c|c|}
\hline Method & Target/Units & Units & Advantages & Disadvantages & References \\
\hline PCR & $\begin{array}{l}\text { Specific DNA } \\
\text { sequence } \\
\text { (gene) }\end{array}$ & Presence/ absence & $\begin{array}{l}\text { Robust, well } \\
\text { documented }\end{array}$ & $\begin{array}{c}\text { Highly specific; must } \\
\text { have known ARG } \\
\text { sequence and primers } \\
\text { Semi-quantitative }\end{array}$ & Sung et al., 2014 \\
\hline q-PCR & Specific gene & $\begin{array}{l}\text { Gene copies per } \\
\text { mass or gene } \\
\text { copies/16S gene } \\
\text { copies }\end{array}$ & $\begin{array}{l}\text { Robust, well } \\
\text { documented } \\
\text { Quantitative }\end{array}$ & $\begin{array}{l}\text { Must have known ARG } \\
\text { sequence and primers } \\
\text { Multiplexing is } \\
\text { challenging } \\
\text { May need probes to } \\
\text { improve specificity } \\
\text { Equipment and } \\
\text { reagent costs } \\
\text { conventional PCR } \\
\text { given high throughput }\end{array}$ & $\begin{array}{l}\text { Hu et al., 2017; Narciso- } \\
\text { da-Rocha and Manaia, } \\
2017\end{array}$ \\
\hline q-PCR array & $\begin{array}{l}\text { Hundreds of } \\
\text { genes per array }\end{array}$ & $\begin{array}{l}\text { Gene copies per } \\
\text { mass or gene } \\
\text { copies/16S gene } \\
\text { copies }\end{array}$ & $\begin{array}{l}\text { Quantitative } \\
\text { for multiple } \\
\text { genes }\end{array}$ & $\begin{array}{l}\text { Limited to known ARG } \\
\text { sequence and primers } \\
\text { Specificity and } \\
\text { detection limit difficult } \\
\text { to verify } \\
\text { Equipment costs much } \\
\text { greater than } \\
\text { conventional PCR }\end{array}$ & Xie et al., 2016 \\
\hline $\begin{array}{l}\text { Metagenomic } \\
\text { sequencing }\end{array}$ & $\begin{array}{l}\text { All DNA, depth } \\
\text { reflects number } \\
\text { of total } \\
\text { sequences }\end{array}$ & $\begin{array}{c}\text { Relative abundance } \\
\text { of ARGs (ARG } \\
\text { sequences per total } \\
\text { sequences) } \\
\text { or } \\
\text { ARG percentage } \\
\text { (ARG type per total } \\
\text { housekeeping gene } \\
\text { sequences) }\end{array}$ & $\begin{array}{l}\text { Captures full } \\
\text { range of } \\
\text { resistance } \\
\text { elements } \\
\text { without } \\
\text { selecting } \\
\text { targets a priori } \\
\text { Sensitivity is } \\
\text { directly related } \\
\text { to the number } \\
\text { of sequences } \\
\text { returned } \\
\text { (depth) }\end{array}$ & $\begin{array}{c}\text { Difficult to confirm } \\
\text { that a true ARG has } \\
\text { been detected. } \\
\text { Not quantitative. } \\
\text { Available databases } \\
\text { for comparison are } \\
\text { limited, but rapidly } \\
\text { growing. } \\
\text { Expensive }(\sim 4 \mathrm{~K} \text { for } \\
\text { shallow sequencing of } \\
\sim 10 \text { samples) }\end{array}$ & $\begin{array}{l}\text { Ju and Zhang, } \\
\text { 2015; Bengtsson-Palme et } \\
\text { al., 2016; Munk et al., } \\
2017\end{array}$ \\
\hline $\begin{array}{l}\text { Functional } \\
\text { Metagenomics }\end{array}$ & Gene & Presence/absence & $\begin{array}{l}\text { Can discover } \\
\text { new ARGs. } \\
\text { Verifies } \\
\text { functionality of } \\
\text { ARG. }\end{array}$ & $\begin{array}{c}\text { Highly tedious and } \\
\text { labor-intensive. A } \\
\text { great deal of effort can } \\
\text { be expended to } \\
\text { discover } 1 \text { new ARG. }\end{array}$ & $\begin{array}{l}\text { Bengtsson-Palme et al., } \\
\text { 2014; dos Santos et al., } \\
\qquad 2017\end{array}$ \\
\hline
\end{tabular}

Ideally, all ARGs would be monitored, both in terms of types present, their relative abundances, their propensity to be horizontally transferred (i.e., occurring on a mobile genetic element such as a plasmid or transposon), and the types of bacterial hosts in which they are present. This is precisely what is sought to be achieved via the new and emerging field of metagenomics (Pal et al., 2016). Through application of next-generation DNA sequencing technology (e.g., Illumina sequencing, pyrosequencing) and most recently third-generation DNA sequencing technology (e.g., PacBio or MinION), DNA extracted from environmental samples can be fragmented and directly sequenced. Through bioinformatics pipelines, the DNA reads can then be compared against available databases of known ARGs, such as RESFINDER for BLAST analysis (Zankari et al., 2012; Zankari et al., 2013), MGMAPPER for mapping of reads

(https://cge.cbs.dtu.dk/services/MGmapper/)(Petersen et al., 2017), and MEGARes (Lakin et al., 2017), Antibiotic
Resistance Gene-ANNOTation (ARG-ANNOT) (Gupta et al., 2014), the Antimicrobial Resistance Database Project (Liu and Pop, 2009), the Comprehensive Antimicrobial Resistance Database (McArthur et al., 2013; Jia et al., 2017), the Structured Antibiotic Resistance Gene Database (ARGs-OAP; (Yang et al., 2016) or deepARG (Arango-Argoty et al., 2017). In this manner, a profile of the types and numbers of ARGs detected in a sample can be obtained and compared with other samples using various bioinformatics techniques and graphical representations. Metagenomics has been successfully applied in this manner for monitoring ARGs in wastewater treatment plants (Schluter et al., 2008; Wang et al., 2013; Yang et al., 2014; Li et al., 2015a; Munck et al., 2015; Zhang et al., 2015a; Bengtsson-Palme et al., 2016; Hu et al., 2016; Karkman et al., 2016; Ma et al., 2016b), biosolids (McCall et al., 2016; Tao et al., 2016; Rowe et al., 2016; Tang et al., 2016), manure (Agga et al., 2015), soil (Yan et al., 2016), rivers (Garner et al., 2016; Rowe et al., 2016), sediments (Cummings et al., 2011), and 
estuaries (Port et al., 2012). However, next-generation DNA sequencing technologies are still costly and require a high level of expertise, currently restricting metagenomic analysis to the realm of research, although that may soon change.

To cut costs, metagenomic studies often sequence multiple samples per lane, with a shallow sequencing approach multiplexing ten wastewater activated sludge samples per Illumina lane or flow cell and successfully being able to detect and compare ARG profiles (Cai and Zhang, 2013). However, deep sequencing (e.g., one sample per Illumina lane), which is even more costly, may be required to filter out dominant and housekeeping genes and identify rare ARGs of interest. Deep sequencing is also typically necessary to link ARGs with host bacteria and genetic elements, along with sophisticated genome assembly techniques, which require a high level of expertise, are not standardized, and still error prone. DNA sequencing costs are predicted to decrease significantly in the coming years and new user-friendly technologies are currently in the pipeline (Schmidt et al., 2017). In particular, third-generation DNA technologies reduce cost and produce longer reads, which will facilitate assembly and thus identifying which hosts carry ARGs and if they are associated with mobile genetic elements. Thus, the metagenomic approach may soon be a widely accessible gold standard for ARG monitoring.

While metagenomic methods are still under development, quantitative polymerase chain reaction (qPCR) has become a well-established tool for monitoring ARG targets of interest. Using one of several available fluorescence-based assays, a real-time PCR instrument, and appropriate standard curve, it is possible to precisely quantify the ARG/determinant of interest. Such quantitation has been of value for quantifying anthropogenic inputs of ARGs to the environment (Pruden et al., 2012; Graham et al., 2016) and assessing the effectiveness of waste treatment technologies (Ma et al., 2011; Narciso-da-Rocha and Manaia, 2017). The disadvantage of qPCR is that, while it is less time-demanding than culture-based techniques, it is realistically only possible to include a handful of ARGs in any monitoring scheme. This necessitates selecting appropriate ARG monitoring targets.

\subsection{Environmental Reservoirs}

Antibiotic resistance has existed on earth for millennia, and evolved with bacteria; thus, it is important to benchmark success of AMR control/mitigation with respect to an appropriate background (Rothrock et al., 2016). Background distributions of various levels of ARGs exist, along with various mechanism described above for their selection and transfer. Therefore, the concern addressed in this chapter with respect to environmental reservoirs of ARGs is the intensification ('hot-spot') development of the resistome and potential for vertical (within the species) or horizontal (between species) gene transfer within the environment (von Wintersdorff et al., 2016) and ultimately to clinically-relevant bacteria associated with sanitationrelated technologies.
While evidence for the role of environmental pathways for AMR of clinical relevance exists today (Quintela-Baluja et al., 2015), it has not yet become a high priority for healthcare professionals. This apparent lack of awareness has also impacted on financing studies to clarify the role of the environment, with few funded projects thus far focusing on food, livestock wastes, and companion animals (e.g., EU Project

E F F O R , http://www.effort-against-amr.eu/page/activities.php, Songe et al., 2017). Therefore, we present examples of AMR environmental reservoirs that particularly highlight the scientific plausibility/concern should mitigation/reduction approaches not be considered with sanitation systems. While most understanding of AMR is associated with bacteria and their bacteriophages, enteric viral, parasitic protozoan and helminth pathogens could also develop antimicrobial resistance, but are not capable of horizontal gene transfer in the sanitation environment the way that bacteria are. Table 4 provides a comprehensive summary of likely efficacy of AMR reduction by sanitation systems at the time of writing this Chapter. However, it is important to note that some report on a culture-basis while others by molecular methods and information about efficacies of these treatments is evolving.

\subsection{Presence and transfer of relevant genes within environmental bacteria}

Ample evidence exists for native (autochthonous) bacteria in the environment taking up and maintaining ARGs (Walsh et al., 2011; Cantas et al., 2013), such as vancomycin-resistant Enterococcus faecium (VREfm) (Sacramento et al., 2016). Indeed, the study of antibioticresistance mechanisms in environmental bacteria is shedding light on novel pathways of resistance found in pathogens (Spanogiannopoulos et al., 2014). Particular concern may come from spore-forming clostridia, given the persistence of their spores in soil systems (Gondim-Porto et al., 2016) and the increasing resistance within pathogens like Clostridium difficile (Zaiss et al., 2010; Garner et al., 2015). However, as with a range of bacterial pathogens, non-pathogenic sub-species or clades are likely to exist in the environment that are not only poorly documented, but would confound the relevance of detections, as in this case for $C$. difficile with ARGs in the environment (Janezic et al., 2016). Furthermore, ongoing genetic studies are leading to bacterial reclassifications, with $C$. difficile now assigned to a new genus, Clostridioides difficile (Lawson et al., 2016).

Amongst the various determinants associated with ARG capture, uptake and transfer within bacteria (Singer et al., 2016), class 1 integrons (e.g. intI1, integrase of class 1 integrons) are often involved (Stalder et al., 2012). Class 1 integrons routinely contain mobile antibiotic and biocideresistance genes (Stokes and Gillings, 2011) and are described as part of the "mobilome" (Tian et al., 2016). For example, class 1 integrons were validated as a proxy for anthropogenic ARG inputs to the Thames River basin by Amos et al. (2015), who modeled various contributing factors impacting environmental resistome presence and determined that wastewater effluent was the major source. Class 1 integrons may also reflect the history of ARG input to soil, as seen in sludge amended soils (Burch et al., 2014), 
which may respond in a similar way to soils impacted by open defecation or applied excreta following a range of treatment options.

Given that ARGs and corresponding bacteria and environments in which they have been identified have been fairly widely surveyed at this point and are quite numerous, here we focus on exemplar scenarios (e.g., worldwide spread of mcr-1 gene resistance within a year (Liakopoulos et al., 2016)) and opportunities to limit the potential enrichment of "hot-spots" for ARG amplification (Pruden et al., 2013). The efficacy of such interventions could then be tracked with respect to the prevalence of AMR surrogates, such as class 1 integrons or other "indicator" ARGs identified in Table 3 (e.g. (Spanogiannopoulos et al., 2014; Blaak et al., 2015a), and minimizing the environmental release of antibiotics, biocides and metals that are known to increase selection for AMR (Di Cesare et al., 2016; Singer et al., 2016).

\subsection{Presence and transfer of extracellular genes within the environment}

In addition to whole cells containing ARGs, there is a need to consider extracellular ARGs. As only focusing on genes within allochthonous (i.e., introduced) bacteria (or other cellular pathogens) may miss development or release of important ARGs. Hence, in addition to the use of molecular methods to assess the environmental resistome, as described above, we need to consider extracellular ARG uptake, by naked (transformation) and bacteriophage (transduction) mechanisms. While novel gene uptake by transduction is generally considered important (Ross and Topp, 2015), there are mixed views as to the significance of ARGs within environmental bacteriophages on the development of environmental AMR due to misinterpretation from sequence information (Enault et al., 2017) and given the high concentration of active host cells generally needed to provide interactions, as seen in clinical environments (Stanczak-Mrozek et al., 2015). Nonetheless, environmental transduction has been demonstrated (Anand et al., 2016) and the persistence of ARGs is clearly influenced by the greater persistence of bacteriophages in the environment versus ARB (Calero-Cáceres and Muniesa, 2016) or novel superspreaders (Keen et al., 2017). Therefore, sanitation processes that are focused on enteric virus nucleic acid elimination may also be effective in reducing the release and presence of bacteriophage/plasmid-mediated environmental ARGs.

Furthermore, naked DNA uptake of ARGs (transformation) is also possible during or after inactivation of pathogens and their subsequent release of ARGs (genomic or plasmid-borne). For example, advanced oxidation processes generate reactive oxygen species (ROS), which can damage cell membranes and elicit cellular SOS responses. The SOS response has been shown to increase integrase activity and the rate of gene recombination, increase the rate of HGT (Beaber et al., 2004; Guerin et al., 2009; Baharoglu et al., 2012), and increase competence which in turn may promote plasmid transformation in wastewater treatment (Ding et al., 2016). Other environmental stresses (Aertsen and Michiels, 2006), such as heat shock (Layton and Foster, 2005), starvation (Bernier et al., 2013), high hydrostatic pressure (Aertsen et al., 2004), and high $\mathrm{pH}$, as well as the presence of antimicrobials, disinfection chemicals or UV have also been shown to induce the SOS response (Poole, 2012).

\subsection{Fate of AMR-related genes within sanitation systems}

Given the above general discussion of likely mechanisms for environmental ARG amplification and spread, some guidance is presented below to highlight possible management options to reduce environmental AMR spread via sanitation systems.

\subsubsection{Amplification (enrichment) versus reduction}

In general, manures and sewage sludge (biosolids) are recognized matrices with the highest concentration of ARGs and antimicrobials, possibly up to 1000-times the concentrations present in wastewater effluents (Munir et al., 2011). Therefore, it is most important to control ARG release from these excreta-related solids. Significant reductions in ARGs are possible via bio-drying sludge (10-15 day process) compared to traditional composting (30-50 days). For example, Zhang et al. (2016a) demonstrated by molecular methods, some 0.4 to $3.1 \log _{10}$ reductions in ARGs and a similar level of reduction in mobile genetic elements with bio-drying. The success in reductions was related to changes in the microbial communities that developed (microbiomes), which largely reflected physiochemical changes, such as $\mathrm{pH}$, available nutrients, temperature, and moisture content (Zhang et al., 2016a). Hence, manipulation of the microbiome, as also seen in anaerobic digestion and composting (Youngquist et al., 2016), influences the fate of ARGs. With regards to persistent spore-forming bacteria as indicators it seems that the fecal indicator Clostridium perfringens may be a conservative indicator for ARG-containing $C$. difficile spores with regards to thermal (composting) treatment (Xu et al., 2016).

A recent review by Youngquist et al. (2016) suggests that mesophilic anaerobic digestion virtually eliminates ARB when assayed using culture-based methods (Beneragama et al., 2013). However, ARGs are readily moved across viable bacteria in the community, most of which are unlikely to be culturable on standard agar plates. This highlights the importance of utilizing direct measures (such as sequence-based resistome or qPCR assays) to detect ARGs. While most of these molecular-based methods fail to discriminate between dead and living targeted cells, quantitative changes can still be followed. For example, Christgen et al. (2015) demonstrated that a combination of anaerobic digestion followed by aerobic polishing provided the most reduction in ARGs identified by sequencing in an evaluation of six different treatment trains for treating domestic wastewater. Nonetheless, while the anaerobicaerobic sequencing treatment of domestic wastewater effectively reduced aminoglycoside, tetracycline, and $\beta$ lactam ARG levels relative to anaerobic units, sulfonamide and chloramphenicol ARG levels were largely unaffected by 
any treatment and there was also a general increase in multi-drug resistance presence in all effluents (Christgen et al., 2015). Hence, further treatment or containment of effluent would be necessary to minimize potential AMR issues, as subsequent soil application may not result in effective removal across the range of ARG and their determinants (Burch et al., 2014). Despite the genetic burden in carrying a functional integrase, modeling indicates that the presence of this gene enables a population to respond rapidly to changing selective pressures, so maintenance of class 1 integrons is no surprise (Engelstadter et al., 2016).

In summary, ARG transfer and potential increase within the native microbiota is very likely in any sanitation system where microbial activity is encouraged (such as anaerobic digestion, trickling filters, aerobic reactors, compost, stored urine or wastewater lagoons), and in general, because of the higher solids content including microorganisms, sludge/biosolids/biofilms that support high density growth. Key factors for AMR transfer include selecting factors (antimicrobial, biocide and heavy metal concentrations), biotic processes (biofilm growth, high bacteriophage density, mobile genetic elements, etc.), and certain abiotic conditions $(\mathrm{pH}$, temperature, moisture content, sunlight) that favor microbial activity. Specific issues with different treatment (unit) processes are discussed next.

\subsection{Reductions by Sanitation Management}

Treatment technologies that provide benefits for inactivating bacterial pathogens and which also may help to minimize the spread of antibiotic resistance.

\subsection{Fate of ARGs versus host bacteria by unit processes}

Most sanitation processes involve bacterial activity and given the above discussion on inevitable mobilization of ARGs to members of the resident microbial community, we need to focus on actions documented to reduce ARGs or influential mobilome elements, as recently reviewed (Bouki et al., 2013; Rizzo et al., 2013b; Sharma et al., 2016). Common unit processes are now briefly reviewed below so as to give a sense of which issues to consider, in addition to traditional focus on pathogens.

\subsubsection{Dry sanitation and collected urine streams}

If lime or similar (fly ash) types of alkali compounds are added to dry sanitation systems and the $\mathrm{pH}$ exceeds 10 , then much of the above discussion on $\mathrm{pH}$ and ammonia effects would be expected to be applicable in terms of reducing ARGs occurrence. Desiccation may also be important via inactivation of microbial processes and, in general, 12 months storage time is recommended for pathogen control (Schönning et al., 2007).

For collected urine (yellow water), there is a high likelihood of residual antimicrobial compound presence (i.e., selecting factors), along with antibiotic-resistant urinary tract bacterial pathogens (Ejrnaes, 2011). Hence, minimizing transfer to the highly active bacteria community within separated urine streams is important, but largely an unreported aspect to date (Pynnonen and Tuhkanen, 2014; Bischel et al., 2015). Current pathogen control regulations for source-diverted urine recommend around six months of storage for pathogen inactivation (Höglund et al., 2002; Tilley, 2016); however, reductions in antimicrobials may only be some $42-99 \%$ for anti-tuberculosis drugs and < $50 \%$ for some antivirals and antibiotics (Jaatinen et al., 2016). Therefore, additional treatments, such as UV alone or in combination with peroxydisulfate, are recommended to further eliminate antimicrobials in collected urine (Zhang et al., 2016b). However, based on the principles described above, the native microbiota within stored urine would be expected to accumulate ARGs, hence soil application or further treatment is recommended to reduce AMR issues.

\subsubsection{Wetland/pond sanitation systems}

Sediments within sanitation wetland/pond systems and receiving water sediments may be "hot-spots" for AMR development (Cummings et al., 2011), due to increased microbial activity and influx of wastewater-borne ARGs compared to free-waters above. Nonetheless, constructed wetlands have been shown to effectively reduce ARGs $\left(\log _{10}\right.$ reductions of 0.26-3.3) and antimicrobials (Huang et al., 2015; Chen et al., 2016) and thus could provide a net protective effect prior to effluent reuse applications in agriculture. 
Table 7. Lagoons, oxidation ditches, and wetlands

\begin{tabular}{|c|c|c|c|c|c|c|c|}
\hline $\begin{array}{c}\text { WWT } \\
\text { Process }\end{array}$ & $\begin{array}{c}\text { System Scale } \\
\text { (i.e., full, pilot, } \\
\text { bench, etc.) }\end{array}$ & Location & $\begin{array}{c}\text { ARG/ARB or } \\
\text { bacterial } \\
\text { indicator }\end{array}$ & $\begin{array}{c}\text { Concentration } \\
\text { In }^{\mathrm{a}}\end{array}$ & $\begin{array}{c}\text { Concentration } \\
\text { Outa }\end{array}$ & $\begin{array}{c}\text { Log } \\
\text { Removal }\end{array}$ & Reference \\
\hline \multirow{7}{*}{$\begin{array}{l}\text { Oxidation } \\
\text { ditch }+ \\
\text { Secondary } \\
\text { settling } \\
\text { (with partial } \\
\text { sludge } \\
\text { recycling) }\end{array}$} & \multirow{7}{*}{$\begin{array}{l}\text { Municipal WWTP } \\
\text { using Oxidation } \\
\text { ditch as main } \\
\text { treatment process. } \\
\text { (Data estimated } \\
\text { from Figure 2.) }\end{array}$} & \multirow{7}{*}{$\begin{array}{l}\text { Hefei, } \\
\text { China }\end{array}$} & 16S rRNA & $1.81 \mathrm{E}+07^{\mathrm{bd}}$ & $6.74 \mathrm{E}+06$ & 0.429 & \multirow{7}{*}{$\begin{array}{l}\text { Li et al., } \\
2017\end{array}$} \\
\hline & & & intI1 & $3.00 \mathrm{E}+05^{\mathrm{bd}}$ & $9.00 \mathrm{E}+04$ & 0.52 & \\
\hline & & & sul1 & $4.00 \mathrm{E}+06^{\mathrm{bd}}$ & $9.00 \mathrm{E}+04$ & 1.65 & \\
\hline & & & sul2 & $2.00 \mathrm{E}+05^{\mathrm{bd}}$ & $6.00 \mathrm{E}+04$ & 0.52 & \\
\hline & & & tetO & $2.00 \mathrm{E}+04^{\mathrm{bd}}$ & $4.00 \mathrm{E}+03$ & 0.70 & \\
\hline & & & tetQ & $1.00 \mathrm{E}+06^{\mathrm{bd}}$ & $4.00 \mathrm{E}+04$ & 1.40 & \\
\hline & & & tetw & $3.00 \mathrm{E}+03^{\mathrm{bd}}$ & $1.00 \mathrm{E}+03$ & 0.48 & \\
\hline \multirow{8}{*}{$\begin{array}{l}\text { Oxidation } \\
\text { Ditch }\end{array}$} & \multirow{8}{*}{$\begin{array}{c}\text { Full scale WWTP } \\
\text { serving a } \\
\text { population of } \\
\text { 285,000. WWTP } \\
\text { processes include } \\
\text { Grit Removal, } \\
\text { Oxidation Ditch, } \\
\text { and Constructed } \\
\text { Wetland. } \\
\text { (Data estimated } \\
\text { from values } \\
\text { reported on Figure } \\
\text { 2) }\end{array}$} & \multirow{8}{*}{$\begin{array}{l}\text { Hangzhou, } \\
\text { China }\end{array}$} & $16 \mathrm{~S}$ rRNA & $7.11 \mathrm{E}+08^{\mathrm{bd}}$ & $1.74 \mathrm{E}+07$ & 1.611 & \multirow{16}{*}{$\begin{array}{l}\text { Chen and } \\
\text { Zhang, } \\
2013\end{array}$} \\
\hline & & & intI1 & $8.00 \mathrm{E}+07^{\text {bd }}$ & $2.00 \mathrm{E}+06$ & 1.60 & \\
\hline & & & sul1 & $1.00 \mathrm{E}+07^{\mathrm{bd}}$ & $5.00 \mathrm{E}+05$ & 1.30 & \\
\hline & & & sul2 & $2.00 \mathrm{E}+07^{\mathrm{bd}}$ & $8.00 \mathrm{E}+05$ & 1.40 & \\
\hline & & & tet $\mathrm{M}$ & $4.00 \mathrm{E}+07^{\mathrm{bd}}$ & $6.00 \mathrm{E}+04$ & 2.82 & \\
\hline & & & tetO & $3.00 \mathrm{E}+07^{\mathrm{bd}}$ & $4.00 \mathrm{E}+04$ & 2.88 & \\
\hline & & & tetQ & $8.00 \mathrm{E}+07^{\mathrm{bd}}$ & $1.00 \mathrm{E}+05$ & 2.90 & \\
\hline & & & tetw & $6.00 \mathrm{E}+07^{\mathrm{bd}}$ & $1.00 \mathrm{E}+06$ & 1.78 & \\
\hline \multirow{9}{*}{$\begin{array}{l}\text { Oxidation } \\
\text { Ditch }\end{array}$} & \multirow{9}{*}{$\begin{array}{c}\text { Full scale WWTP } \\
\text { serving a } \\
\text { population of } \\
\text { 94,500. Processes } \\
\text { include: Grit } \\
\text { Removal, } \\
\text { Oxidation Ditch } \\
\text { and Biological } \\
\text { Aerated Filter. } \\
\text { (Data estimated } \\
\text { from values } \\
\text { reported on Figure } \\
\text { 2) }\end{array}$} & \multirow{8}{*}{$\begin{array}{l}\text { Hangzhou, } \\
\text { China }\end{array}$} & 16S rRNA & $4.28 \mathrm{E}+09^{\mathrm{bd}}$ & $4.81 \mathrm{E}+07$ & 1.949 & \\
\hline & & & intI1 & $8.00 \mathrm{E}+07^{\mathrm{bd}}$ & $2.00 \mathrm{E}+06$ & 1.60 & \\
\hline & & & sul1 & $8.00 \mathrm{E}+07^{\mathrm{bd}}$ & $3.00 \mathrm{E}+05$ & 2.43 & \\
\hline & & & sul2 & $2.00 \mathrm{E}+08^{\mathrm{bd}}$ & $3.00 \mathrm{E}+06$ & 1.82 & \\
\hline & & & tetM & $1.00 \mathrm{E}+07^{\mathrm{bd}}$ & $5.00 \mathrm{E}+04$ & 2.30 & \\
\hline & & & tetO & $4.00 \mathrm{E}+06^{\mathrm{bd}}$ & $1.00 \mathrm{E}+04$ & 2.60 & \\
\hline & & & tetQ & $1.00 \mathrm{E}+07^{\mathrm{bd}}$ & $2.00 \mathrm{E}+04$ & 2.70 & \\
\hline & & & tetw & $1.00 \mathrm{E}+08^{\mathrm{bd}}$ & $4.00 \mathrm{E}+05$ & 2.40 & \\
\hline & & & intI1 & $1.16 \mathrm{E}+10^{\mathrm{bd}}$ & $2.88 \mathrm{E}+09$ & 0.605 & \multirow{13}{*}{$\begin{array}{l}\text { Li et al., } \\
2015\end{array}$} \\
\hline \multirow{12}{*}{$\begin{array}{l}\text { Oxidation } \\
\text { ditch } \\
\text { (aerobic } \\
\text { tank) }\end{array}$} & \multirow{12}{*}{$\begin{array}{c}\text { Full WWTP } \\
\text { receiving domestic } \\
\text { sewage from } \\
\text { urban and } \\
\text { residential areas, } \\
\text { serving 300,000 } \\
\text { people } \\
\text { (Composite } \\
\text { samples collected } \\
\text { March to May, } \\
\text { 2013. Sample } \\
\text { concentrations } \\
\text { estimated with } \\
\text { WebPlotDigitizer } \\
\text { from figure S3) }\end{array}$} & \multirow{12}{*}{$\begin{array}{l}\text { Linan } \\
\text { City, } \\
\text { China }\end{array}$} & sul1 & $9.09 \mathrm{E}+09^{\mathrm{bd}}$ & $4.30 \mathrm{E}+09$ & 0.325 & \\
\hline & & & sul2 & $1.67 \mathrm{E}+09^{\mathrm{bd}}$ & $7.66 \mathrm{E}+08$ & 0.338 & \\
\hline & & & tetA & $7.78 \mathrm{E}+08^{\mathrm{bd}}$ & $8.50 \mathrm{E}+07$ & 0.962 & \\
\hline & & & tetB & $4.14 \mathrm{E}+07^{\mathrm{bd}}$ & $4.93 \mathrm{E}+06$ & 0.924 & \\
\hline & & & tetC & $8.60 \mathrm{E}+08^{\mathrm{bd}}$ & $1.79 \mathrm{E}+08$ & 0.682 & \\
\hline & & & tet $\mathrm{G}$ & $1.51 \mathrm{E}+09^{\mathrm{bd}}$ & $3.90 \mathrm{E}+08$ & 0.588 & \\
\hline & & & tetL & $4.85 \mathrm{E}+07^{\mathrm{bd}}$ & $1.49 \mathrm{E}+07$ & 0.513 & \\
\hline & & & tet $\mathrm{M}$ & $3.43 \mathrm{E}+08^{\mathrm{bd}}$ & $6.39 E+06$ & 1.730 & \\
\hline & & & tetO & $4.24 \mathrm{E}+09^{\mathrm{bd}}$ & $6.45 E+08$ & 0.818 & \\
\hline & & & tetQ & $1.18 \mathrm{E}+10^{\mathrm{bd}}$ & $1.25 \mathrm{E}+09$ & 0.975 & \\
\hline & & & tetw & $5.04 \mathrm{E}+09^{\mathrm{bd}}$ & $3.43 E+08$ & 1.167 & \\
\hline & & & tetX & $8.85 E+08^{b d}$ & $1.67 \mathrm{E}+08$ & 0.724 & \\
\hline
\end{tabular}




\begin{tabular}{|c|c|c|c|c|c|c|c|}
\hline $\begin{array}{c}\text { WWT } \\
\text { Process }\end{array}$ & $\begin{array}{c}\text { System Scale } \\
\text { (i.e., full, pilot, } \\
\text { bench, etc.) }\end{array}$ & Location & $\begin{array}{l}\text { ARG/ARB or } \\
\text { bacterial } \\
\text { indicator } \\
\end{array}$ & $\begin{array}{c}\text { Concentration } \\
\text { In }^{\mathrm{a}}\end{array}$ & $\begin{array}{c}\text { Concentration } \\
\text { Outa }\end{array}$ & $\begin{array}{c}{ }^{\mathrm{L}} \text { og } \\
\text { Removal }\end{array}$ & Reference \\
\hline \multirow{13}{*}{$\begin{array}{l}\text { Aerobic } \\
\text { tank/triple } \\
\text { oxidation } \\
\text { ditch }\end{array}$} & \multirow{13}{*}{$\begin{array}{l}\text { Full scale medium } \\
\text { sized WWTP } \\
\text { capacity 60,000t } \\
\text { (Composite } \\
\text { samples collected } \\
\text { September and } \\
\text { October, 2013; } \\
\text { concentration } \\
\text { values estimated } \\
\text { from Figure 3) }\end{array}$} & \multirow{13}{*}{$\begin{array}{c}\text { Eastern } \\
\text { China }\end{array}$} & intI1 & $1.50 \mathrm{E}+10^{\mathrm{bd}}$ & $8.00 \mathrm{E}+08$ & 1.273 & \multirow{13}{*}{$\begin{array}{l}\text { Li et al., } \\
2016\end{array}$} \\
\hline & & & sul1 & $2.00 \mathrm{E}+10^{\mathrm{bd}}$ & $1.30 \mathrm{E}+09$ & 1.187 & \\
\hline & & & sul2 & $5.00 \mathrm{E}+06^{\mathrm{bd}}$ & $5.50 \mathrm{E}+05$ & 0.959 & \\
\hline & & & tetA & $5.00 \mathrm{E}+09^{\mathrm{bd}}$ & $4.00 \mathrm{E}+08$ & 1.097 & \\
\hline & & & tetB & $8.00 \mathrm{E}+07^{\mathrm{bd}}$ & $8.00 \mathrm{E}+06$ & 1.000 & \\
\hline & & & tetC & $7.00 \mathrm{E}+10^{\mathrm{bd}}$ & $3.00 \mathrm{E}+09$ & 1.368 & \\
\hline & & & tet $\mathrm{G}$ & $5.00 \mathrm{E}+09^{\mathrm{bd}}$ & $8.50 \mathrm{E}+08$ & 0.770 & \\
\hline & & & tetL & $8.00 \mathrm{E}+07^{\mathrm{bd}}$ & $9.00 \mathrm{E}+06$ & 0.949 & \\
\hline & & & tetM & $4.50 \mathrm{E}+08^{\mathrm{bd}}$ & $2.00 \mathrm{E}+07$ & 1.352 & \\
\hline & & & tetO & $8.00 \mathrm{E}+08^{\mathrm{bd}}$ & $5.00 \mathrm{E}+07$ & 1.204 & \\
\hline & & & tetQ & $1.30 \mathrm{E}+09^{\mathrm{bd}}$ & $1.00 \mathrm{E}+08$ & 1.114 & \\
\hline & & & tetw & $9.00 \mathrm{E}+07^{\mathrm{bd}}$ & $8.00 \mathrm{E}+06$ & 1.051 & \\
\hline & & & tetX & $1.50 \mathrm{E}+09^{\mathrm{bd}}$ & $8.00 \mathrm{E}+08$ & 0.273 & \\
\hline \multirow{7}{*}{$\begin{array}{l}\text { Grit removal } \\
+ \text { Oxidation } \\
\text { ditch }+ \\
\text { Biological } \\
\text { aerated } \\
\text { filter }\end{array}$} & $\begin{array}{c}\text { Full scale WWTP } \\
\text { serving a }\end{array}$ & & intI1 & $8.00 \mathrm{E}+07^{\mathrm{bd}}$ & - & 2.00 & \multirow{7}{*}{$\begin{array}{l}\text { Chen and } \\
\text { Zhang, } \\
2013\end{array}$} \\
\hline & population of & & sul1 & $8.00 \mathrm{E}+07^{\mathrm{bd}}$ & - & 2.63 & \\
\hline & & & sul2 & $2.00 \mathrm{E}+08^{\mathrm{bd}}$ & - & 1.70 & \\
\hline & $\begin{array}{c}\text { Removal, } \\
\text { Oxidation Ditch }\end{array}$ & $\begin{array}{l}\text { Hangzhou, } \\
\text { China }\end{array}$ & tet $\mathrm{M}$ & $1.00 \mathrm{E}+07^{\mathrm{bd}}$ & - & 3.50 & \\
\hline & $\begin{array}{l}\text { and Biological } \\
\text { Aerated Filter. }\end{array}$ & & tetO & $4.00 \mathrm{E}+06^{\mathrm{bd}}$ & - & 3.75 & \\
\hline & (Data estimated & & tetQ & $1.00 \mathrm{E}+07^{\text {bd }}$ & - & 3.75 & \\
\hline & 4)$. & & tetW & $1.00 \mathrm{E}+08^{\mathrm{bd}}$ & - & 3.35 & \\
\hline \multirow{10}{*}{$\begin{array}{l}\text { Waste } \\
\text { stabilization } \\
\text { pond }\end{array}$} & $\begin{array}{c}\text { Arctic waste } \\
\text { stabilization ponds } \\
\text { (WSPs); serving }\end{array}$ & & 16S rRNA & $6.00 \mathrm{E}+06^{\mathrm{bd}}$ & $3.50 \mathrm{E}+06$ & 0.234 & \multirow{10}{*}{$\begin{array}{c}\text { Neudorf et } \\
\text { al., } 2017\end{array}$} \\
\hline & $\begin{array}{l}7542 \text { residents; } \\
\text { receiving domestic }\end{array}$ & & blaCTX-M & $8.00 \mathrm{E}+00^{\mathrm{bd}}$ & $1.00 \mathrm{E}+01$ & -0.097 & \\
\hline & $\begin{array}{l}\text { and hospital waste } \\
\text { (WWTP uses a } \\
\text { Salsnes filter, }\end{array}$ & & blaTEM & $1.50 \mathrm{E}+01^{\mathrm{bd}}$ & $6.00 \mathrm{E}+00$ & 0.398 & \\
\hline & $\begin{array}{l}\text { effluent is then } \\
\text { continuously } \\
\text { decanted into }\end{array}$ & Iqaluit; & ermB & $3.70 \mathrm{E}+01^{\mathrm{bd}}$ & $1.80 \mathrm{E}+01$ & 0.313 & \\
\hline & $\begin{array}{c}\text { Frobisher's Bay. } \\
\text { Grab samples }\end{array}$ & Island in & intl1 & $8.60 \mathrm{E}+01^{\mathrm{bd}}$ & $4.20 \mathrm{E}+01$ & 0.311 & \\
\hline & $\begin{array}{c}\text { taken twice } \\
\text { September, } 2015\end{array}$ & $\begin{array}{l}\text { Region of } \\
\text { Nunavut, }\end{array}$ & mecA & $1.00 \mathrm{E}+01^{\mathrm{bd}}$ & $1.00 \mathrm{E}+01$ & 0.000 & \\
\hline & $\begin{array}{l}\text { November } 2015 . \\
\text { In September the }\end{array}$ & Canada & $q n r S$ & $8.00 \mathrm{E}+00^{\mathrm{bd}}$ & $1.30 \mathrm{E}+01$ & -0.211 & \\
\hline & $\begin{array}{l}\text { WWTP was not } \\
\text { operational so a }\end{array}$ & & sul1 & $9.00 \mathrm{E}+01^{\mathrm{bd}}$ & $3.70 \mathrm{E}+01$ & 0.386 & \\
\hline & $\begin{array}{l}\text { waste stabilization } \\
\text { pond was used; } \\
\text { concentration }\end{array}$ & & sul2 & $9.50 \mathrm{E}+01^{\mathrm{bd}}$ & $4.00 \mathrm{E}+01$ & 0.376 & \\
\hline & $\begin{array}{l}\text { estimates from } \\
\text { figure } 3 a)\end{array}$ & & tetO & $3.50 \mathrm{E}+01^{\mathrm{bd}}$ & $2.70 \mathrm{E}+01$ & 0.113 & \\
\hline
\end{tabular}




\begin{tabular}{|c|c|c|c|c|c|c|c|}
\hline $\begin{array}{c}\text { WWT } \\
\text { Process }\end{array}$ & $\begin{array}{l}\text { System Scale } \\
\text { (i.e., full, pilot, } \\
\text { bench, etc.) }\end{array}$ & Location & $\begin{array}{l}\text { ARG/ARB or } \\
\text { bacterial } \\
\text { indicator }\end{array}$ & $\begin{array}{l}\text { Concentration } \\
\operatorname{In}^{\mathrm{a}}\end{array}$ & $\begin{array}{c}\text { Concentration } \\
\text { Outa }\end{array}$ & $\begin{array}{c}\text { Log } \\
\text { Removal }\end{array}$ & Reference \\
\hline \multirow{10}{*}{$\begin{array}{l}\text { Waste } \\
\text { stabilization } \\
\text { ponds }\end{array}$} & \multirow{10}{*}{$\begin{array}{l}\text { Arctic waste } \\
\text { stabilization ponds } \\
\text { (WSPs); serving } \\
1673 \text { residents } \\
\text { (A waste } \\
\text { stabilization pond } \\
\text { is used, it is } \\
\text { emptied into the } \\
\text { ocean each year in } \\
\text { September. Grab } \\
\text { samples taken in } \\
\text { September } 2013 \\
\text { and 2014, } \\
\text { concentration } \\
\text { estimates from } \\
\text { figure 3c) }\end{array}$} & \multirow{10}{*}{$\begin{array}{l}\text { Pond } \\
\text { Inlet; } \\
\text { Baffin } \\
\text { Island in } \\
\text { the } \\
\text { Qikiqtani } \\
\text { Region of } \\
\text { Nunavut, } \\
\text { Canada }\end{array}$} & 16S rRNA & $6.00 \mathrm{E}+07^{\mathrm{bd}}$ & $5.00 \mathrm{E}+07$ & 0.079 & \multirow{10}{*}{$\begin{array}{l}\text { Neudorf et } \\
\text { al., } 2017\end{array}$} \\
\hline & & & blaCTX-M & $2.10 \mathrm{E}+01^{\mathrm{bd}}$ & $2.00 \mathrm{E}+01$ & 0.021 & \\
\hline & & & blaTEM & $7.00 \mathrm{E}+00^{\mathrm{bd}}$ & $9.00 \mathrm{E}+00$ & -0.109 & \\
\hline & & & ermB & $5.50 \mathrm{E}+01^{\mathrm{bd}}$ & $4.65 E+01$ & 0.073 & \\
\hline & & & intl1 & $2.50 \mathrm{E}+01^{\mathrm{bd}}$ & $2.90 \mathrm{E}+01$ & -0.064 & \\
\hline & & & mecA & $6.00 \mathrm{E}+00^{\mathrm{bd}}$ & $6.50 \mathrm{E}+00$ & -0.035 & \\
\hline & & & qnrS & $6.80 \mathrm{E}+01^{\mathrm{bd}}$ & $7.00 \mathrm{E}+01$ & -0.013 & \\
\hline & & & sul1 & $3.90 \mathrm{E}+01^{\mathrm{bd}}$ & $3.20 \mathrm{E}+01$ & 0.086 & \\
\hline & & & sul2 & $1.80 \mathrm{E}+01^{\mathrm{bd}}$ & $1.90 \mathrm{E}+01$ & -0.023 & \\
\hline & & & tetO & $3.95 \mathrm{E}+01^{\mathrm{bd}}$ & $3.80 \mathrm{E}+01$ & 0.017 & \\
\hline \multirow{10}{*}{$\begin{array}{l}\text { Waste } \\
\text { stabilization } \\
\text { ponds }\end{array}$} & \multirow{10}{*}{$\begin{array}{l}\text { Arctic waste } \\
\text { stabilization ponds } \\
\text { (WSPs); serving } \\
983 \text { residents } \\
\text { (Two waste } \\
\text { stabilization ponds } \\
\text { are used in series. } \\
\text { Grab samples were } \\
\text { taken June, July, } \\
\text { September } 2013 \\
\text { and June, } \\
\text { September 2014; } \\
\text { concentration } \\
\text { estimates from } \\
\text { figure 3b) }\end{array}$} & & 16S rRNA & $5.00 \mathrm{E}+06^{\mathrm{bd}}$ & $2.00 \mathrm{E}+06$ & 0.398 & \multirow{10}{*}{$\begin{array}{c}\text { Neudorf et } \\
\text { al., } 2017\end{array}$} \\
\hline & & & blaCTX-M & $1.40 \mathrm{E}+01^{\mathrm{bd}}$ & $8.00 \mathrm{E}+00$ & 0.243 & \\
\hline & & Clyde & blaTEM & $3.50 \mathrm{E}+01^{\mathrm{bd}}$ & $1.40 \mathrm{E}+01$ & 0.398 & \\
\hline & & $\begin{array}{l}\text { River; } \\
\text { Baffin }\end{array}$ & ermB & $4.00 \mathrm{E}+01^{\mathrm{bd}}$ & $1.60 \mathrm{E}+01$ & 0.398 & \\
\hline & & $\begin{array}{l}\text { Island in } \\
\text { the }\end{array}$ & intl1 & $1.28 \mathrm{E}+02^{\mathrm{bd}}$ & $6.00 \mathrm{E}+01$ & 0.329 & \\
\hline & & Qikiqtani & mecA & $8.00 \mathrm{E}+00^{\mathrm{bd}}$ & $1.00 \mathrm{E}+01$ & -0.097 & \\
\hline & & $\begin{array}{l}\text { Region of } \\
\text { Nunavut }\end{array}$ & $q n r S$ & $1.10 \mathrm{E}+01^{\mathrm{bd}}$ & $1.00 \mathrm{E}+01$ & 0.041 & \\
\hline & & Canada & sul1 & $7.70 \mathrm{E}+01^{\mathrm{bd}}$ & $5.30 \mathrm{E}+01$ & 0.162 & \\
\hline & & & sul2 & $8.90 \mathrm{E}+01^{\mathrm{bd}}$ & $8.40 \mathrm{E}+01$ & 0.025 & \\
\hline & & & tetO & $5.00 \mathrm{E}+01^{\mathrm{bd}}$ & $3.40 \mathrm{E}+01$ & 0.167 & \\
\hline \multirow{8}{*}{$\begin{array}{l}\text { Naturally } \\
\text { aerated } \\
\text { lagoon }\end{array}$} & $\begin{array}{l}\text { Full WWTP } \\
\text { receiving domestic } \\
(50 \%) \text { and }\end{array}$ & \multirow{8}{*}{$\begin{array}{l}\text { Moknine, } \\
\text { Tunisia }\end{array}$} & 16S rRNA & $2.31 \mathrm{E}+08^{\mathrm{bd}}$ & $3.67 \mathrm{E}+08$ & -0.201 & \multirow{8}{*}{$\begin{array}{l}\text { Rafraf et } \\
\text { al., } 2016\end{array}$} \\
\hline & $\begin{array}{c}\text { pretreated } \\
\text { industrial sewage } \\
(50 \%), \text { serving }\end{array}$ & & blaCTX-M & $5.54 \mathrm{E}+03^{\mathrm{bd}}$ & $1.60 \mathrm{E}+04$ & -0.461 & \\
\hline & $\begin{array}{l}\text { 165,184 people } \\
\text { (Grab samples }\end{array}$ & & blaTEM & $3.83 \mathrm{E}+05^{\mathrm{bd}}$ & $2.26 \mathrm{E}+05$ & 0.229 & \\
\hline & $\begin{array}{c}\text { taken in triplicate. } \\
16 \mathrm{~S} \text { rRNA } \\
\text { concentration } \\
\text { values from table }\end{array}$ & & ermB & $1.75 \mathrm{E}+05^{\mathrm{bd}}$ & $7.16 \mathrm{E}+05$ & -0.612 & \\
\hline & $\begin{array}{l}\text { 2, ARG gene/16S } \\
\text { rRNA copies }\end{array}$ & & intI1 & $1.36 \mathrm{E}+07^{\mathrm{bd}}$ & $4.73 E+06$ & 0.459 & \\
\hline & $\begin{array}{c}\text { values from table } \\
\text { S2, absolute } \\
\text { abundance was }\end{array}$ & & qnrA & $3.34 \mathrm{E}+04^{\mathrm{bd}}$ & $5.82 \mathrm{E}+05$ & -1.241 & \\
\hline & $\begin{array}{l}\text { then back- } \\
\text { calculated. DNA } \\
\text { extraction kit }\end{array}$ & & $q n r S$ & $\mathrm{ND}^{\mathrm{bd}}$ & $2.42 \mathrm{E}+04$ & $\geq-4.38^{*}$ & \\
\hline & $\begin{array}{l}\text { used: DneasyBlood } \\
\text { \& Tissue Kit) }\end{array}$ & & sul1 & $1.75 \mathrm{E}+07^{\mathrm{bd}}$ & $2.21 \mathrm{E}+06$ & 0.899 & \\
\hline
\end{tabular}




\begin{tabular}{|c|c|c|c|c|c|c|c|}
\hline $\begin{array}{c}\text { WWT } \\
\text { Process }\end{array}$ & $\begin{array}{c}\text { System Scale } \\
\text { (i.e., full, pilot, } \\
\text { bench, etc.) }\end{array}$ & Location & $\begin{array}{l}\text { ARG/ARB or } \\
\text { bacterial } \\
\text { indicator }\end{array}$ & $\begin{array}{c}\text { Concentration } \\
\operatorname{In}^{\mathrm{a}}\end{array}$ & $\begin{array}{c}\text { Concentration } \\
\text { Outa }\end{array}$ & $\begin{array}{c}\text { Log } \\
\text { Removal }\end{array}$ & Reference \\
\hline \multirow{8}{*}{$\begin{array}{l}\text { Constructed } \\
\text { wetland }\end{array}$} & Full scale WWTP & \multirow{8}{*}{$\begin{array}{l}\text { Hangzhou, } \\
\text { China }\end{array}$} & 16S rRNA & $1.74 \mathrm{E}+07^{\mathrm{bd}}$ & $1.18 \mathrm{E}+06$ & 1.169 & \multirow{8}{*}{$\begin{array}{l}\text { Chen and } \\
\text { Zhang, } \\
2013\end{array}$} \\
\hline & $\begin{array}{c}\text { serving a } \\
\text { population of }\end{array}$ & & intI1 & $2.00 \mathrm{E}+06^{\mathrm{bd}}$ & $1.00 \mathrm{E}+05$ & 1.30 & \\
\hline & & & sul1 & $5.00 \mathrm{E}+05^{\mathrm{bd}}$ & $1.00 \mathrm{E}+04$ & 1.70 & \\
\hline & & & sul2 & $8.00 \mathrm{E}+05^{\mathrm{bd}}$ & $1.00 \mathrm{E}+05$ & 0.90 & \\
\hline & and Constructed & & tet $\mathrm{M}$ & $6.00 \mathrm{E}+04^{\mathrm{bd}}$ & $1.00 \mathrm{E}+03$ & 1.78 & \\
\hline & $\begin{array}{c}\text { Wetland. } \\
\text { (Data estimated }\end{array}$ & & tetO & $4.00 \mathrm{E}+04^{\mathrm{bd}}$ & $6.00 \mathrm{E}+02$ & 1.82 & \\
\hline & from values & & tetQ & $1.00 \mathrm{E}+05^{\mathrm{bd}}$ & $8.00 \mathrm{E}+02$ & 2.10 & \\
\hline & $\begin{array}{l}\text { reported on Figure } \\
2 \text { and 5) }\end{array}$ & & tetW & $1.00 \mathrm{E}+06^{\mathrm{bd}}$ & $3.00 \mathrm{E}+04$ & 1.52 & \\
\hline $\begin{array}{l}\text { Integrated } \\
\text { surface flow } \\
\text { constructed } \\
\text { wetland }\end{array}$ & $\begin{array}{l}\text { ICW treating rural } \\
\text { domestic sewage } \\
\text { from roughly } 4000 \\
\text { people. Operated } \\
\text { for } 10 \text { years. } \\
\text { (Data obtained } \\
\text { from Table S7) }\end{array}$ & $\begin{array}{c}\text { Nanchang, } \\
\text { Jiangxi } \\
\text { province, } \\
\text { China; } \\
\text { Winter }\end{array}$ & intI1 & $1.82 \mathrm{E}+06^{\mathrm{bd}}$ & $6.36 \mathrm{E}+05$ & 0.457 & \multirow{2}{*}{$\begin{array}{l}\text { Fang et } \\
\text { al., } 2017\end{array}$} \\
\hline $\begin{array}{l}\text { Integrated } \\
\text { surface flow } \\
\text { constructed } \\
\text { wetland }\end{array}$ & $\begin{array}{l}\text { ICW treating rural } \\
\text { domestic sewage } \\
\text { from roughly } 4000 \\
\text { people. Operated } \\
\text { for } 10 \text { years. } \\
\text { (Data obtained } \\
\text { from Table S7) }\end{array}$ & $\begin{array}{l}\text { Nanchang, } \\
\text { Jiangxi } \\
\text { province, } \\
\text { China; } \\
\text { Summer }\end{array}$ & intI1 & $2.18 \mathrm{E}+06^{\mathrm{bd}}$ & $1.14 \mathrm{E}+06$ & 0.282 & \\
\hline $\begin{array}{l}\text { Integrated } \\
\text { surface flow } \\
\text { constructed } \\
\text { wetland }\end{array}$ & $\begin{array}{l}\text { ICW treating rural } \\
\text { domestic sewage } \\
\text { from roughly } 4000 \\
\text { people. Operated } \\
\text { for } 10 \text { years. } \\
\text { (Data obtained } \\
\text { from Table S2) }\end{array}$ & $\begin{array}{c}\text { Nanchang, } \\
\text { Jiangxi } \\
\text { province, } \\
\text { China; } \\
\text { Winter }\end{array}$ & $\begin{array}{l}\text { Sum of } 14 \text { ARGs } \\
\text { (sul1, sul2, sul3, } \\
\text { tet } \mathrm{A}, \text { tetB, tetC, } \\
\text { tet } \mathrm{E}, \text { tet } \mathrm{H}, \text { tet } \mathrm{M}, \\
\text { tetO, tet } \mathrm{W}, \text { qnrS, } \\
\text { qnrB, qepA) }\end{array}$ & $8.41 \mathrm{E}+06^{\mathrm{bd}}$ & $1.87 \mathrm{E}+06$ & 0.653 & \multirow{2}{*}{$\begin{array}{l}\text { Fang et } \\
\text { al., } 2017\end{array}$} \\
\hline $\begin{array}{l}\text { Integrated } \\
\text { surface flow } \\
\text { constructed } \\
\text { wetland }\end{array}$ & $\begin{array}{l}\text { ICW treating rural } \\
\text { domestic sewage } \\
\text { from roughly } 4000 \\
\text { people. Operated } \\
\text { for } 10 \text { years. } \\
\text { (Data obtained } \\
\text { from Table S2) }\end{array}$ & $\begin{array}{l}\text { Nanchang, } \\
\text { Jiangxi } \\
\text { province, } \\
\text { China; } \\
\text { Summer }\end{array}$ & $\begin{array}{l}\text { Sum of } 14 \text { ARGs } \\
\text { (sul1, sul2, sul3, } \\
\text { tetA, tet } \mathrm{B}, \text { tet } \mathrm{C} \\
\text { tet } \mathrm{E}, \text { tet } \mathrm{H}, \text { tet } \mathrm{M}, \\
\text { tet } \mathrm{O} \text {, tet } \mathrm{W}, \text { qnrS, } \\
\text { qnr } \mathrm{B}, \text { qepA) }\end{array}$ & $8.76 \mathrm{E}+06^{\mathrm{bd}}$ & $3.55 \mathrm{E}+06$ & 0.392 & \\
\hline
\end{tabular}




\begin{tabular}{|c|c|c|c|c|c|c|c|}
\hline $\begin{array}{c}\text { WWT } \\
\text { Process }\end{array}$ & $\begin{array}{c}\text { System Scale } \\
\text { (i.e., full, pilot, } \\
\text { bench, etc.) }\end{array}$ & Location & $\begin{array}{c}\text { ARG/ARB or } \\
\text { bacterial } \\
\text { indicator } \\
\end{array}$ & $\begin{array}{c}\text { Concentration } \\
\operatorname{In}^{\mathrm{a}}\end{array}$ & $\begin{array}{c}\text { Concentration } \\
\text { Outa }\end{array}$ & $\begin{array}{c}\text { Log } \\
\text { Removal }\end{array}$ & Reference \\
\hline $\begin{array}{l}\text { Oxidation } \\
\text { Ditch } \\
\text { (Aerobic } \\
\text { treatment) }\end{array}$ & $\begin{array}{l}\text { WWTP with } 60,000 \\
\text { m}^{3} \text { capacity and } \\
\text { serving about } \\
300,000 \text { residents } \\
\text { from urban and } \\
\text { residential areas. } \\
\text { WWTP } \\
\text { configuration } \\
\text { consists of grid } \\
\text { screen, anaerobic } \\
\text { tank, oxidation } \\
\text { ditch (aerobic } \\
\text { tank) and UV } \\
\text { disinfection plus } \\
\text { constructed } \\
\text { wetland system } \\
\text { prior to finally } \\
\text { discharging onto a } \\
\text { lake. } \\
\text { (Triplicate } \\
\text { composite samples } \\
\text { were collected } \\
\text { over 24-h periods } \\
\text { with 3-h intervals. } \\
\text { Values reported } \\
\text { were estimated } \\
\text { from Figure 2.) }\end{array}$ & $\begin{array}{l}\text { Linan } \\
\text { City, } \\
\text { eastern } \\
\text { China }\end{array}$ & $\begin{array}{c}\text { ARB (Tetracycline } \\
+ \\
\text { Sulfamethoxazole) } \\
\text { (R2A Agar }+ \\
\text { tetracycline }+ \\
\text { sulfamethoxazole) }\end{array}$ & $3.68 \mathrm{E}+04^{\mathrm{ce}}$ & $6.58 \mathrm{E}+04$ & -0.142 & $\begin{array}{l}\text { Li et al., } \\
2015\end{array}$ \\
\hline $\begin{array}{l}\text { Constructed } \\
\text { wetland + } \\
\text { UV } \\
\text { Disinfection }\end{array}$ & $\begin{array}{l}\text { WWTP with } 60,000 \\
\mathrm{~m}^{3} \text { capacity and } \\
\text { serving about } \\
300,000 \text { residents } \\
\text { from urban and } \\
\text { residential areas. } \\
\text { WWTP } \\
\text { configuration } \\
\text { consists of grid } \\
\text { screen, anaerobic } \\
\text { tank, oxidation } \\
\text { ditch (aerobic } \\
\text { tank) and UV } \\
\text { disinfection plus } \\
\text { constructed } \\
\text { wetland system } \\
\text { prior to finally } \\
\text { discharging onto a } \\
\text { lake. } \\
\text { (Triplicate } \\
\text { composite samples } \\
\text { were collected } \\
\text { over 24-h periods } \\
\text { with 3-h intervals. } \\
\text { Values reported } \\
\text { were estimated }\end{array}$ & $\begin{array}{l}\text { Linan } \\
\text { City, } \\
\text { eastern } \\
\text { China }\end{array}$ & $\begin{array}{c}\text { ARB (Tetracycline } \\
+ \\
\text { Sulfamethoxazole) } \\
\text { (R2A Agar }+ \\
\text { tetracycline }+ \\
\text { sulfamethoxazole) }\end{array}$ & $2.78 \mathrm{E}+06^{\mathrm{ce}}$ & $1.00 \mathrm{E}+06$ & 1.167 & $\begin{array}{c}\text { Li et al., } \\
2015\end{array}$ \\
\hline
\end{tabular}

${ }^{a}$ Removals calculated directly from values reported in the reference, when available, or extracted from the published figures using WebPlotDigitizer or manually when this was not possible; ${ }^{b} \mathrm{qPCR}$; ${ }^{\mathrm{c}}$ culture-based method; ${ }^{\mathrm{d}} \mathrm{gene}$ copies/ mL; ${ }^{\mathrm{e}} \mathrm{cfu} / \mathrm{mL}$; - not reported; *values calculated using 1 gene copy/mL as the value for ND, NA or $<$ LOQ; ND = not detected 
3.1.3 Centralized wastewater treatment plants (WWTP)

While conventional WWTPs do not appear to reduce the (normalized) integron copy number, they do reduce the diversity of gene cassette arrays measured in the raw wastewater (Stalder et al., 2014), the plasmid resistome (Szczepanowski et al., 2009), and ARGs generally by some
33-98\% (Tao et al., 2014). These findings imply aerobic treatment may be beneficial with respect to abating ARGs, but not a complete barrier to AMR. To reduce the cost of aeration, a combined anaerobic-aerobic system is also effective in reducing many but not all ARG types (Christgen et al., 2015), as discussed in Section 3.2.1.

3.1.3.1 Removal by primary settling and sedimentation

Table 8. Grit removal, settling, sedimentation

\begin{tabular}{|c|c|c|c|c|c|c|c|}
\hline $\begin{array}{c}\text { WWT } \\
\text { Process }\end{array}$ & $\begin{array}{c}\text { System Scale } \\
\text { (i.e., full, pilot, } \\
\text { bench, etc.) }\end{array}$ & Location & $\begin{array}{l}\text { IRG/ARB or } \\
\text { bacterial } \\
\text { indicator }\end{array}$ & $\begin{array}{c}\text { Concentration } \\
\operatorname{In}^{\mathbf{a}, b, c}\end{array}$ & $\begin{array}{c}\text { Concentration } \\
\text { Out }^{\mathbf{a}, \mathbf{b}, \mathbf{c}}\end{array}$ & $\begin{array}{c}\text { Log } \\
\text { Removal }\end{array}$ & Reference \\
\hline Grit Removal & $\begin{array}{c}\text { Full scale WWTP } \\
\text { serving a population } \\
\text { of } 285,000 \text {. WWTP } \\
\text { processes include Grit } \\
\text { Removal, Oxidation } \\
\text { Ditch, and } \\
\text { Constructed Wetland. } \\
\text { (Data estimated from } \\
\text { values reported on } \\
\text { Figure 2) }\end{array}$ & $\begin{array}{c}\text { Hangzhou, } \\
\text { China }\end{array}$ & $\begin{array}{c}16 \mathrm{~S} \text { rRNA } \\
\text { intII } \\
\text { sul1 } \\
\text { sul2 } \\
\text { tetM } \\
\text { tetO } \\
\text { tetQ } \\
\text { tetW }\end{array}$ & $\begin{array}{r}8.28 \mathrm{E}+08 \\
6.00 \mathrm{E}+07 \\
1.00 \mathrm{E}+07 \\
2.00 \mathrm{E}+07 \\
5.00 \mathrm{E}+06 \\
4.00 \mathrm{E}+06 \\
9.00 \mathrm{E}+06 \\
7.00 \mathrm{E}+07\end{array}$ & $\begin{array}{l}7.11 \mathrm{E}+08 \\
8.00 \mathrm{E}+07 \\
1.00 \mathrm{E}+07 \\
2.00 \mathrm{E}+07 \\
4.00 \mathrm{E}+07 \\
3.00 \mathrm{E}+07 \\
8.00 \mathrm{E}+07 \\
6.00 \mathrm{E}+07\end{array}$ & $\begin{array}{r}0.066 \\
-0.12 \\
0.00 \\
0.00 \\
-0.90 \\
-0.88 \\
-0.95 \\
0.07\end{array}$ & $\begin{array}{l}\text { Chen and } \\
\text { Zhang, } \\
2013\end{array}$ \\
\hline Grit Removal & $\begin{array}{c}\text { Full scale WWTP } \\
\text { serving a population } \\
\text { of } 94,500 \text {. Processes } \\
\text { include: Grit Removal, } \\
\text { Oxidation Ditch and } \\
\text { Biological Aerated } \\
\text { Filter. } \\
\text { (Data estimated from } \\
\text { values reported on } \\
\text { Figure 2) }\end{array}$ & $\begin{array}{l}\text { Hangzhou, } \\
\text { China }\end{array}$ & $\begin{array}{l}\text { 16S rRNA } \\
\text { intI1 } \\
\text { sul1 } \\
\text { sul2 } \\
\text { tetM } \\
\text { tetO } \\
\text { tetQ } \\
\text { tetW }\end{array}$ & $\begin{array}{l}1.56 \mathrm{E}+09 \\
4.00 \mathrm{E}+07 \\
2.00 \mathrm{E}+07 \\
2.00 \mathrm{E}+07 \\
8.00 \mathrm{E}+06 \\
3.00 \mathrm{E}+06 \\
7.00 \mathrm{E}+06 \\
5.00 \mathrm{E}+07\end{array}$ & $\begin{array}{l}4.28 \mathrm{E}+09 \\
8.00 \mathrm{E}+07 \\
8.00 \mathrm{E}+07 \\
2.00 \mathrm{E}+08 \\
1.00 \mathrm{E}+07 \\
4.00 \mathrm{E}+06 \\
1.00 \mathrm{E}+07 \\
1.00 \mathrm{E}+08\end{array}$ & $\begin{array}{l}-0.438 \\
-0.30 \\
-0.60 \\
-1.00 \\
-0.10 \\
-0.12 \\
-0.15 \\
-0.30\end{array}$ & $\begin{array}{l}\text { Chen and } \\
\text { Zhang, } \\
2013\end{array}$ \\
\hline $\begin{array}{l}\text { Aerated grit } \\
\text { removal tank } \\
+ \text { flow } \\
\text { equalization } \\
\text { basin }\end{array}$ & $\begin{array}{c}\text { Full-scale activated } \\
\text { sludge WWTP } \\
\text { (Grab samples } \\
\text { collected during four } \\
\text { sampling events } \\
\text { between July and } \\
\text { December } 2010 . \\
\text { Mean values } \\
\text { estimated from } \\
\text { Figure 4.) }\end{array}$ & $\begin{array}{c}\text { East } \\
\text { Lansing, MI, }\end{array}$ & $\begin{array}{l}\text { sulI } \\
\text { tetO } \\
\text { tetW }\end{array}$ & $\begin{array}{l}2.00 \mathrm{E}+06 \\
5.01 \mathrm{E}+06 \\
3.98 \mathrm{E}+06\end{array}$ & $\begin{array}{l}6.31 E+05 \\
6.31 E+06 \\
3.16 E+06\end{array}$ & $\begin{array}{l}0.50 \\
-0.10 \\
0.10\end{array}$ & $\begin{array}{c}\text { Gao et al., } \\
2012\end{array}$ \\
\hline $\begin{array}{l}\text { Aerated Grit } \\
\text { Chamber }\end{array}$ & $\begin{array}{l}\text { Urban WWTP, serving } \\
\text { 320,000 inhabitants } \\
\text { (Composite samples } \\
\text { collected from December } \\
\text { 2013-June 2014; ARG } \\
\text { concentration estimates } \\
\text { from figure } 4 \text { showing } \\
\text { total ARG abundance) }\end{array}$ & $\begin{array}{l}\text { Shanghai, } \\
\text { China }\end{array}$ & $\begin{array}{c}16 \mathrm{~S} \text { rRNA } \\
\text { ereA } \\
\text { ereB } \\
\text { ermA } \\
\text { ermB } \\
\text { ermC } \\
\text { mefA/mefE } \\
\text { msrA } / m s r B\end{array}$ & $\begin{array}{c}2.00 \mathrm{E}+05 \\
2.63 \mathrm{E}+05 \\
1.00 \mathrm{E}+05 \\
1.86 \mathrm{E}+01 \\
1.50 \mathrm{E}+05 \\
8.91 \mathrm{E}+01 \\
3.00 \mathrm{E}+05 \\
9.12 \mathrm{E}+00\end{array}$ & $\begin{array}{l}9.00 \mathrm{E}+04 \\
1.00 \mathrm{E}+05 \\
1.20 \mathrm{E}+04 \\
1.50 \mathrm{E}+00 \\
2.00 \mathrm{E}+04 \\
2.00 \mathrm{E}+01 \\
4.00 \mathrm{E}+04 \\
9.00 \mathrm{E}+00\end{array}$ & $\begin{array}{c}0.35 \\
0.42 \\
0.92 \\
1.09 \\
0.88 \\
0.65 \\
0.88 \\
0.006\end{array}$ & $\begin{array}{l}\text { Gao et al., } \\
2015\end{array}$ \\
\hline $\begin{array}{l}\text { Fine screen + } \\
\text { Grit removal } \\
\text { + Primary } \\
\text { settling }\end{array}$ & $\begin{array}{c}\text { Full scale WWTP with } \\
\text { average daily flow of } \\
\text { 150,000 m³/d, using a } \\
\text { cyclic activated } \\
\text { sludge system. } \\
\text { (WWTP sampled once } \\
\text { a month from } \\
\text { November } 2013 \text { to } \\
\text { April } 2014 \text {. Median } \\
\text { values estimated from } \\
\text { data presented in } \\
\text { Figure S3.) }\end{array}$ & $\begin{array}{l}\text { Harbin, } \\
\text { China }\end{array}$ & $\begin{array}{l}\text { 16S rRNA } \\
\text { blaCTX-M } \\
\text { intI1 } \\
\text { sul1 } \\
\text { sul2 } \\
\text { tetA } \\
\text { tetO } \\
\text { tetW }\end{array}$ & $\begin{array}{r}5.35 \mathrm{E}+08 \\
2.00 \mathrm{E}+04 \\
7.00 \mathrm{E}+06 \\
4.00 \mathrm{E}+05 \\
1.00 \mathrm{E}+07 \\
4.00 \mathrm{E}+04 \\
4.00 \mathrm{E}+04 \\
2.00 \mathrm{E}+06\end{array}$ & $\begin{array}{l}3.26 \mathrm{E}+08 \\
1.00 \mathrm{E}+04 \\
3.00 \mathrm{E}+06 \\
2.00 \mathrm{E}+05 \\
7.00 \mathrm{E}+06 \\
1.00 \mathrm{E}+04 \\
1.00 \mathrm{E}+04 \\
1.00 \mathrm{E}+06\end{array}$ & $\begin{array}{l}0.22 \\
0.30 \\
0.37 \\
0.30 \\
0.15 \\
0.60 \\
0.60 \\
0.30\end{array}$ & $\begin{array}{l}\text { Wen et al., } \\
2016\end{array}$ \\
\hline
\end{tabular}




\begin{tabular}{|c|c|c|c|c|c|c|c|}
\hline $\begin{array}{c}\text { WWT } \\
\text { Process }\end{array}$ & $\begin{array}{c}\text { System Scale } \\
\text { (i.e., full, pilot, } \\
\text { bench, etc.) }\end{array}$ & Location & $\begin{array}{c}\text { ARG/ARB or } \\
\text { bacterial } \\
\text { indicator } \\
\end{array}$ & $\begin{array}{c}\text { Concentration } \\
\text { In }^{\mathrm{a}, \mathrm{b}, \mathrm{c}}\end{array}$ & $\begin{array}{c}\text { Concentration } \\
\text { Out }^{\mathrm{a}, \mathrm{b}, \mathrm{c}}\end{array}$ & $\begin{array}{c}\text { Log } \\
\text { Removal }\end{array}$ & Reference \\
\hline $\begin{array}{l}\text { Primary } \\
\text { settling }\end{array}$ & $\begin{array}{l}\text { Large full scale WWTP } \\
\text { designed for biological } \\
\text { nitrogen removal } \\
\text { (Median ARG abundance } \\
\text { values from samples } \\
\text { collected monthly over a } \\
\text { year were estimated } \\
\text { from Figure } 2 \text {. } \\
\text { Inlet temp } 14 \pm 3.3 \\
{ }^{\circ} \mathrm{C} \text {. Outlet temp } 14 \pm \\
\left.4.2{ }^{\circ} \mathrm{C} .\right)\end{array}$ & $\begin{array}{l}\text { Gothenburg, } \\
\text { Sweden }\end{array}$ & mecA & $4.00 \mathrm{E}+01$ & $1.80 \mathrm{E}+01$ & 0.35 & $\begin{array}{l}\text { Borjesson } \\
\text { et al., } \\
2009\end{array}$ \\
\hline $\begin{array}{l}\text { Secondary } \\
\text { settling }\end{array}$ & $\begin{array}{c}\text { Large full scale } \\
\text { WWTP designed for } \\
\text { biological nitrogen } \\
\text { removal } \\
\text { (Median ARG } \\
\text { abundance values } \\
\text { from samples } \\
\text { collected monthly } \\
\text { over a year were } \\
\text { estimated from } \\
\text { Figure } 2 . \\
\text { Inlet temp } 14 \pm 3.3 \\
{ }^{\circ} \text { C. Outlet temp } 14 \pm \\
\left.4.2{ }^{\circ} \mathrm{C} .\right)\end{array}$ & $\begin{array}{l}\text { Gothenburg, } \\
\text { Sweden }\end{array}$ & mecA & $4.00 \mathrm{E}+02$ & $3.00 \mathrm{E}+00$ & 2.12 & $\begin{array}{l}\text { Börjesson } \\
\text { et al., } \\
2009\end{array}$ \\
\hline \multirow{8}{*}{$\begin{array}{l}\text { Primary } \\
\text { Settling }\end{array}$} & Full scale WWTP & \multirow{8}{*}{$\begin{array}{l}\text { Hangzhou, } \\
\text { China }\end{array}$} & 16S rRNA & $1.15 \mathrm{E}+09$ & $1.00 \mathrm{E}+09$ & 0.061 & \multirow{8}{*}{$\begin{array}{l}\text { Chen and } \\
\text { Zhang, } \\
2013\end{array}$} \\
\hline & of $2,750,000$. & & intI1 & $9.00 \mathrm{E}+07$ & $8.00 \mathrm{E}+07$ & 0.05 & \\
\hline & $\begin{array}{l}\text { Processes include: } \\
\text { Headworks, Primary }\end{array}$ & & sul1 & $1.00 \mathrm{E}+07$ & $1.00 \mathrm{E}+07$ & 0.00 & \\
\hline & $\begin{array}{l}\text { Settling, Anaerobic- } \\
\text { Anoxic-Oxic biological }\end{array}$ & & sul2 & $3.00 \mathrm{E}+07$ & $3.00 \mathrm{E}+07$ & 0.00 & \\
\hline & treatment, Secondary & & tet $\mathrm{M}$ & $7.00 \mathrm{E}+06$ & $4.00 \mathrm{E}+06$ & 0.24 & \\
\hline & $\begin{array}{l}\text { settling, and UV } \\
\text { disinfection. }\end{array}$ & & tetO & $3.00 \mathrm{E}+06$ & $2.00 \mathrm{E}+06$ & 0.18 & \\
\hline & $\begin{array}{l}\text { (Data estimated from } \\
\text { values reported on }\end{array}$ & & tetQ & $1.00 \mathrm{E}+07$ & $1.00 \mathrm{E}+07$ & 0.00 & \\
\hline & Figure 2) & & tetw & $5.00 \mathrm{E}+07$ & $4.00 \mathrm{E}+07$ & 0.10 & \\
\hline \multirow{9}{*}{$\begin{array}{l}\text { Sedimentatiol } \\
\text { tank }\end{array}$} & Full scale, large & \multirow{9}{*}{$\begin{array}{l}\text { Verbania, } \\
\text { Italy }\end{array}$} & $\operatorname{arsB}$ & $8.50 \mathrm{E}+05$ & $1.74 \mathrm{E}+05$ & 0.689 & \multirow{9}{*}{$\begin{array}{c}\text { Di Cesare } \\
\text { et al., } \\
2015\end{array}$} \\
\hline & $\begin{array}{l}\text { municipal WWTP } \\
\text { receiving domestic }\end{array}$ & & blaCTX-M & $2.63 E+03$ & $4.79 \mathrm{E}+02$ & 0.740 & \\
\hline & sewage and & & blaTEM & $2.11 \mathrm{E}+04$ & $4.79 \mathrm{E}+03$ & 0.644 & \\
\hline & pretreated hospital & & $c z c \mathrm{~A}$ & $6.36 \mathrm{E}+04$ & $1.16 \mathrm{E}+04$ & 0.739 & \\
\hline & on $\begin{array}{c}\text { sewage } \\
\text { (Grab samples }\end{array}$ & & ermB & $7.82 \mathrm{E}+05$ & $8.50 \mathrm{E}+04$ & 0.964 & \\
\hline & $\begin{array}{l}\text { collected July 2nd, } \\
\text { 2015. Mean and }\end{array}$ & & intI1 & $5.10 \mathrm{E}+05$ & $1.21 \mathrm{E}+05$ & 0.625 & \\
\hline & standard deviation & & $q n r S$ & $1.24 \mathrm{E}+06$ & $4.67 \mathrm{E}+05$ & 0.424 & \\
\hline & $\begin{array}{l}\text { values of absolute } \\
\text { abundace from }\end{array}$ & & sul2 & $3.36 \mathrm{E}+05$ & $5.69 \mathrm{E}+04$ & 0.771 & \\
\hline & $\begin{array}{l}\text { abundance rrom lable } \\
\text { S2.) }\end{array}$ & & tetA & $1.99 \mathrm{E}+05$ & $5.05 E+04$ & 0.596 & \\
\hline \multirow{4}{*}{$\begin{array}{l}\text { Primary } \\
\text { settling }\end{array}$} & $\begin{array}{l}\text { Full-scale activated } \\
\text { sludge WWTP } \\
\text { (Grab samples }\end{array}$ & \multirow{8}{*}{$\begin{array}{c}\text { East } \\
\text { Lansing, MI, } \\
\text { USA }\end{array}$} & 16S rRNA & $3.98 \mathrm{E}+09$ & $6.31 \mathrm{E}+09$ & -0.20 & \multirow{8}{*}{$\begin{array}{l}\text { Gao et al., } \\
\quad 2012\end{array}$} \\
\hline & $\begin{array}{l}\text { collected during four } \\
\text { sampling events } \\
\text { between July and }\end{array}$ & & sulI & $6.31 \mathrm{E}+05$ & $1.00 \mathrm{E}+06$ & -0.20 & \\
\hline & $\begin{array}{l}\text { December } 2010 . \\
\text { Mean values }\end{array}$ & & tetO & $6.31 \mathrm{E}+06$ & $1.58 \mathrm{E}+06$ & 0.60 & \\
\hline & $\begin{array}{l}\text { estimated from Figure } \\
4 .)\end{array}$ & & tet $\mathrm{W}$ & $3.16 \mathrm{E}+06$ & $1.00 \mathrm{E}+06$ & 0.50 & \\
\hline \multirow{4}{*}{$\begin{array}{l}\text { Secondary } \\
\text { settling }\end{array}$} & $\begin{array}{l}\text { Full-scale activated } \\
\text { sludge WWTP } \\
\text { (Grab samples }\end{array}$ & & 16S rRNA & $1.58 \mathrm{E}+09$ & $2.00 \mathrm{E}+08$ & 0.90 & \\
\hline & $\begin{array}{l}\text { collected during four } \\
\text { sampling events }\end{array}$ & & sulI & $2.00 \mathrm{E}+05$ & $1.58 \mathrm{E}+04$ & 1.10 & \\
\hline & $\begin{array}{l}\text { December } 2010 . \\
\text { Mean values }\end{array}$ & & tetO & $3.98 \mathrm{E}+04$ & $3.16 \mathrm{E}+04$ & 0.10 & \\
\hline & $\begin{array}{l}\text { estimated from Figure } \\
4 .)\end{array}$ & & tet $\mathrm{W}$ & $3.98 E+04$ & $1.58 \mathrm{E}+04$ & 0.40 & \\
\hline
\end{tabular}




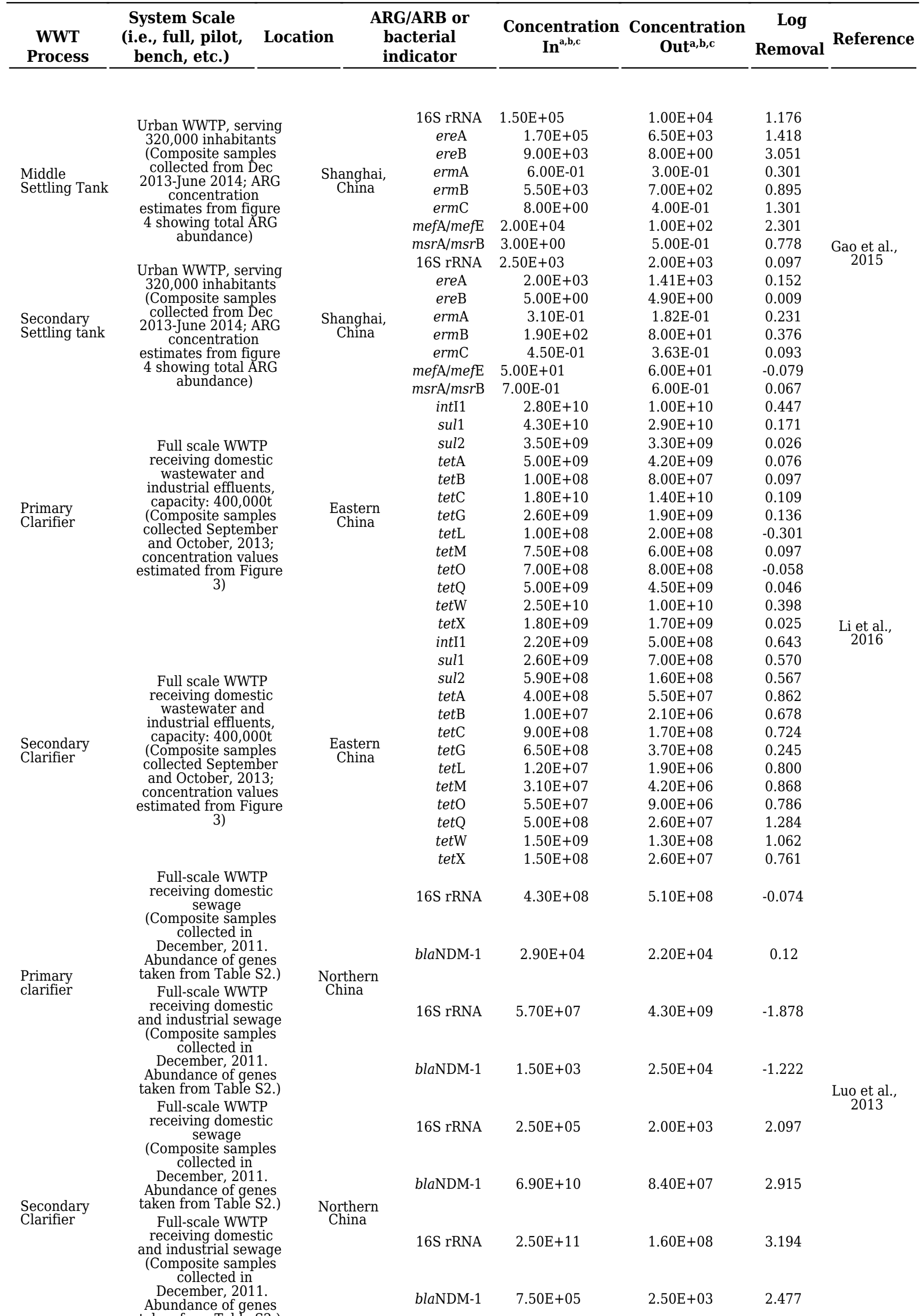




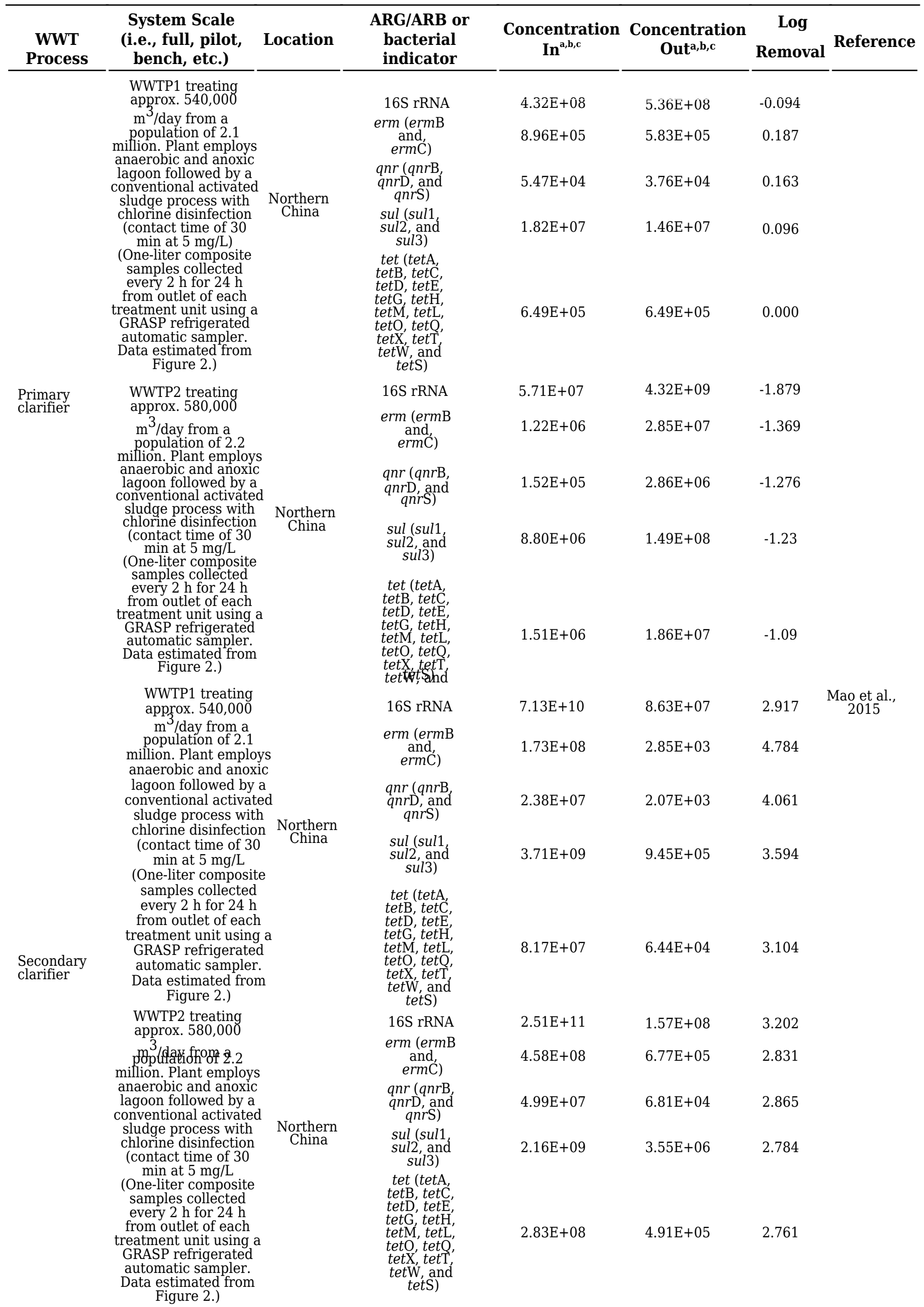

aRemovals calculated directly from values reported in the reference, when available, or extracted from the published figures using WebPlotDigitizer or manually when this was not possible;bqPCR;cgene copies/mL 
Table 9. Aerobic and anaerobic secondary treatment.

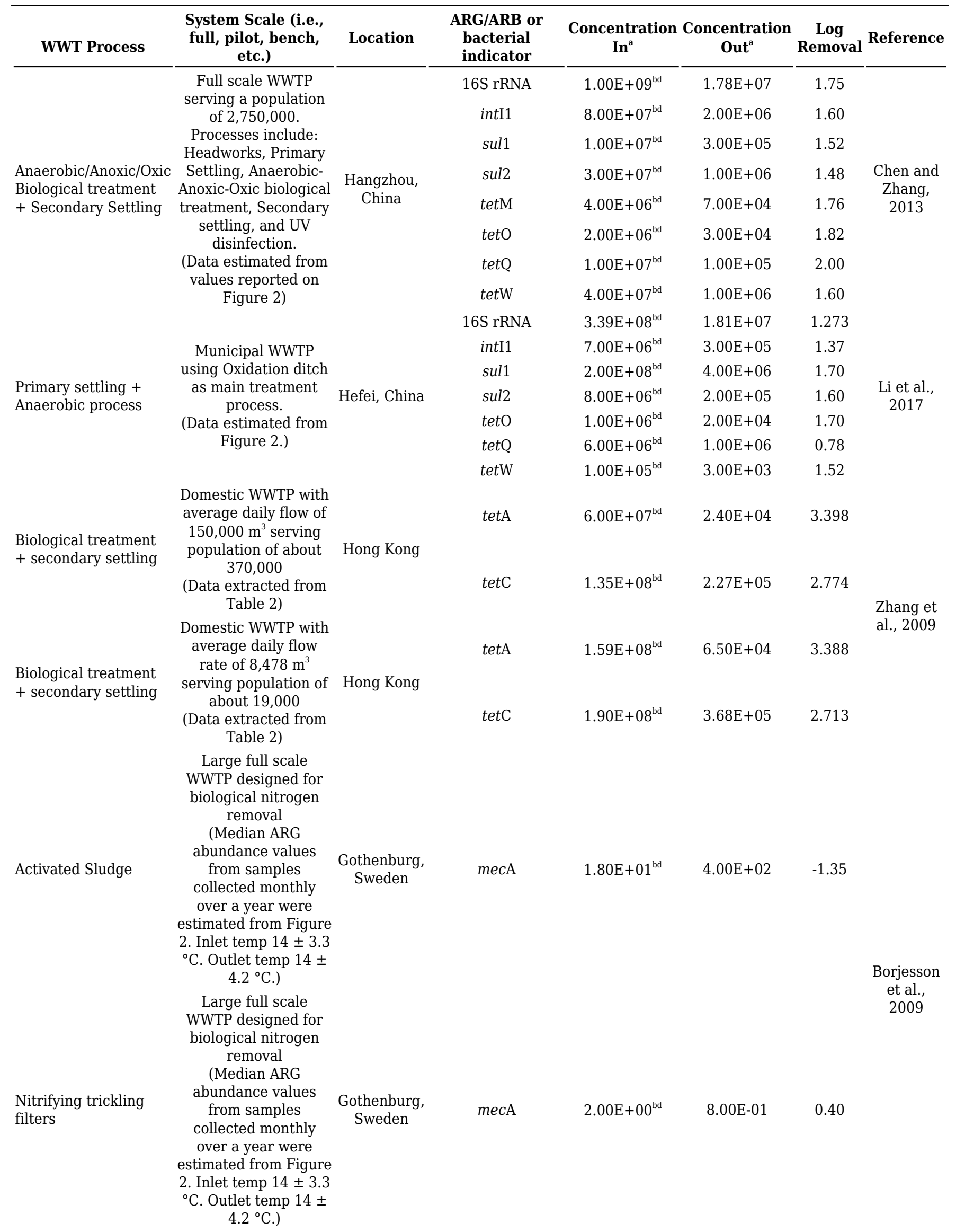




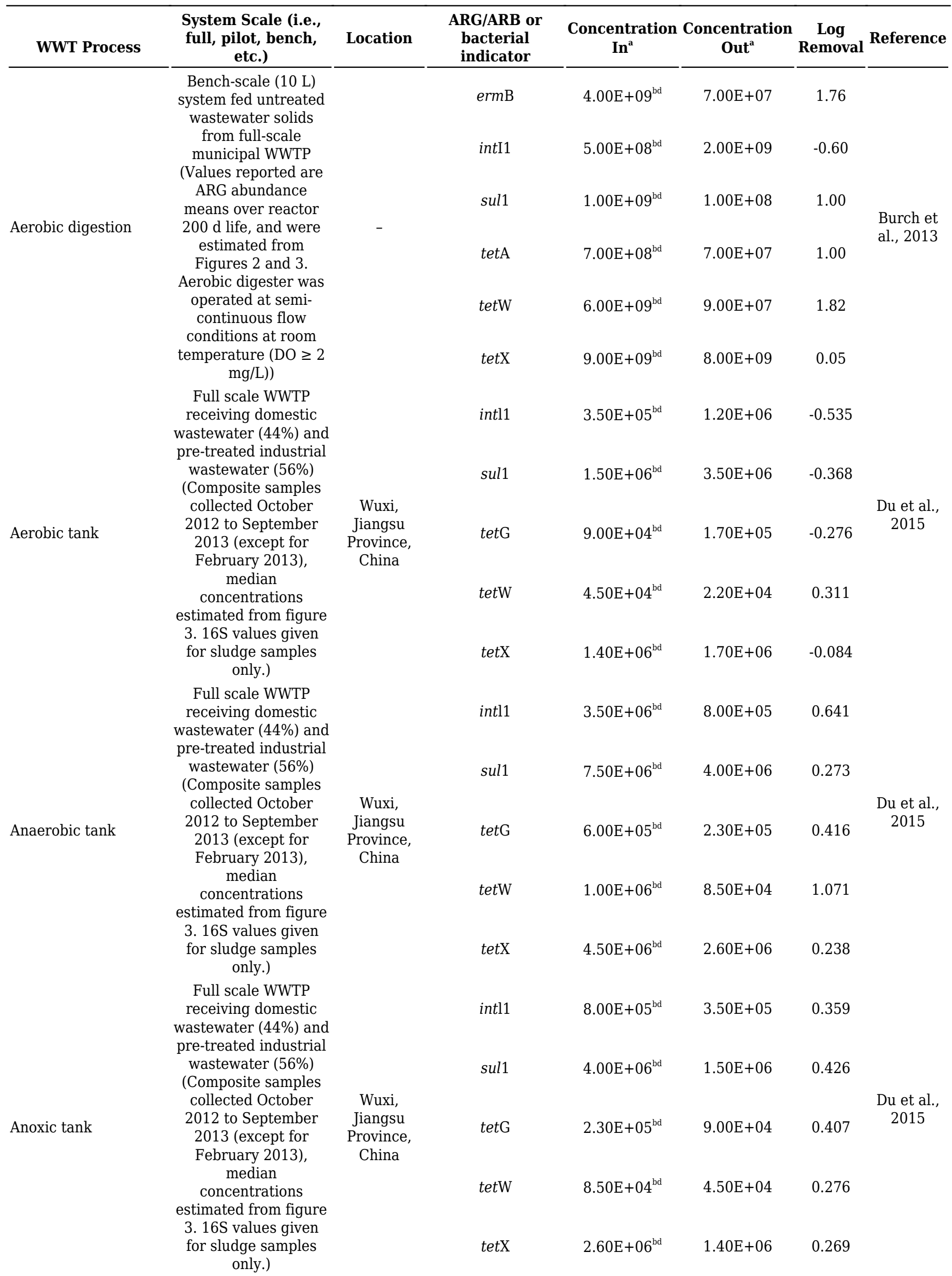




\begin{tabular}{|c|c|c|c|c|c|c|c|}
\hline WWT Process & $\begin{array}{l}\text { System Scale (i.e., } \\
\text { full, pilot, bench, } \\
\text { etc.) }\end{array}$ & Location & $\begin{array}{c}\text { ARG/ARB or } \\
\text { bacterial } \\
\text { indicator } \\
\end{array}$ & $\begin{array}{c}\text { Concentration } \\
\operatorname{In}^{\mathrm{a}}\end{array}$ & $\begin{array}{c}\text { Concentration } \\
\text { Out }^{\mathrm{a}}\end{array}$ & $\begin{array}{c}\text { Log } \\
\text { Removal }\end{array}$ & Reference \\
\hline \multirow{4}{*}{ Anaerobic Tank } & $\begin{array}{c}\text { Full-scale WWTP } \\
\text { receiving domestic } \\
\text { sewage } \\
\text { (Composite samples }\end{array}$ & & 16S rRNA & $5.10 \mathrm{E}+08^{\mathrm{bd}}$ & $5.60 \mathrm{E}+10$ & -2.041 & \multirow{4}{*}{$\begin{array}{l}\text { Luo et al., } \\
2013\end{array}$} \\
\hline & $\begin{array}{c}\text { collected in } \\
\text { December, } 2011 . \\
\text { Abundance of genes } \\
\text { taken from Table S2.) }\end{array}$ & & blaNDM-1 & $2.20 \mathrm{E}+04^{\mathrm{bd}}$ & $2.10 \mathrm{E}+05$ & -0.98 & \\
\hline & $\begin{array}{c}\text { Full-scale WWTP } \\
\text { receiving domestic } \\
\text { and industrial sewage } \\
\text { (Composite samples } \\
\text { collected in }\end{array}$ & & 16S rRNA & $4.30 \mathrm{E}+09^{\mathrm{bd}}$ & $1.40 \mathrm{E}+11$ & -1.513 & \\
\hline & $\begin{array}{c}\text { December, } 2011 . \\
\text { Abundance of genes } \\
\text { taken from Table S2.) }\end{array}$ & & blaNDM-1 & $2.50 \mathrm{E}+04^{\mathrm{bd}}$ & $4.90 \mathrm{E}+05$ & -1.292 & \\
\hline \multirow{4}{*}{ Anoxic Tank } & $\begin{array}{l}\text { Full-scale WWTP } \\
\text { receiving domestic }\end{array}$ & & 16S rRNA & $5.60 \mathrm{E}+10^{\text {bd }}$ & $5.40 \mathrm{E}+10$ & 0.016 & \multirow{4}{*}{$\begin{array}{l}\text { Luo et al., } \\
2013\end{array}$} \\
\hline & sewage & & blaNDM-1 & $2.10 \mathrm{E}+05^{\mathrm{bd}}$ & $2.10 \mathrm{E}+05$ & 0.000 & \\
\hline & $\begin{array}{c}\text { Full-scale WWTP } \\
\text { receiving domestic } \\
\text { and industrial sewage } \\
\text { (Composite samples } \\
\text { collected in }\end{array}$ & $\begin{array}{l}\text { Northern } \\
\text { China }\end{array}$ & 16S rRNA & $1.40 \mathrm{E}+11^{\mathrm{bd}}$ & $1.20 \mathrm{E}+11$ & 0.067 & \\
\hline & $\begin{array}{c}\text { December, } 2011 . \\
\text { Abundance of genes } \\
\text { taken from Table S2.) }\end{array}$ & & blaNDM-1 & $4.90 \mathrm{E}+05^{\mathrm{bd}}$ & $4.40 \mathrm{E}+05$ & 0.047 & \\
\hline \multirow{4}{*}{ Aerated Tank } & $\begin{array}{c}\text { Full-scale WWTP } \\
\text { receiving domestic } \\
\text { sewage } \\
\text { (Composite samples } \\
\text { collected in }\end{array}$ & & 16S rRNA & $5.40 \mathrm{E}+10^{\mathrm{bd}}$ & $6.90 \mathrm{E}+10$ & -0.106 & \multirow{4}{*}{$\begin{array}{l}\text { Luo et al., } \\
2013\end{array}$} \\
\hline & $\begin{array}{c}\text { December, } 2011 . \\
\text { Abundance of genes } \\
\text { taken from Table S2.) }\end{array}$ & & blaNDM-1 & $2.10 \mathrm{E}+05^{\mathrm{bd}}$ & $2.50 \mathrm{E}+05$ & -0.076 & \\
\hline & $\begin{array}{c}\text { Full-scale WWTP } \\
\text { receiving domestic } \\
\text { and industrial sewage } \\
\text { (Composite samples } \\
\text { collected in }\end{array}$ & & 16S rRNA & $1.20 \mathrm{E}+11^{\mathrm{bd}}$ & $2.50 \mathrm{E}+11$ & -0.319 & \\
\hline & $\begin{array}{c}\text { December, } 2011 . \\
\text { Abundance of genes } \\
\text { taken from Table S2.) }\end{array}$ & & blaNDM-1 & $4.40 \mathrm{E}+05^{\mathrm{bd}}$ & $7.50 \mathrm{E}+05$ & -0.232 & \\
\hline \multirow{8}{*}{$\begin{array}{l}\text { First stage } \\
\text { anoxic/aerobic system }\end{array}$} & \multirow{8}{*}{$\begin{array}{l}\text { Urban WWTP, serving } \\
\text { 320,000 inhabitants } \\
\text { (Composite samples } \\
\text { collected from Dec } \\
\text { 2013-June 2014; ARG } \\
\text { concentration } \\
\text { estimates from figure } \\
4 \text { showing total ARG } \\
\text { abundance) }\end{array}$} & \multirow{8}{*}{$\begin{array}{c}\text { Shanghai, } \\
\text { China }\end{array}$} & 16S rRNA & $9.00 \mathrm{E}+04^{\text {bd }}$ & $1.50 \mathrm{E}+05$ & -0.222 & \multirow{16}{*}{$\begin{array}{l}\text { Gao et al., } \\
2015\end{array}$} \\
\hline & & & ereA & $1.00 \mathrm{E}+05^{\mathrm{bd}}$ & $1.70 \mathrm{E}+05$ & -0.230 & \\
\hline & & & ereB & $1.20 \mathrm{E}+04^{\text {bd }}$ & $9.00 \mathrm{E}+03$ & 0.125 & \\
\hline & & & ermA & $1.50 \mathrm{E}+00^{\text {bd }}$ & $6.00 \mathrm{E}-01$ & 0.398 & \\
\hline & & & ermB & $2.00 \mathrm{E}+04^{\mathrm{bd}}$ & $5.50 \mathrm{E}+03$ & 0.561 & \\
\hline & & & ermC & $2.00 \mathrm{E}+01^{\mathrm{bd}}$ & $8.00 \mathrm{E}+00$ & 0.398 & \\
\hline & & & $m e f \mathrm{~A} / m e f \mathrm{E}$ & $4.00 \mathrm{E}+04^{\mathrm{bd}}$ & $2.00 \mathrm{E}+04$ & 0.301 & \\
\hline & & & $m s r \mathrm{~A} / m s r \mathrm{~B}$ & $9.00 \mathrm{E}+00^{\mathrm{bd}}$ & $3.00 \mathrm{E}+00$ & 0.477 & \\
\hline \multirow{8}{*}{$\begin{array}{l}\text { Second-stage } \\
\text { anoxic/aerobic system }\end{array}$} & \multirow{8}{*}{$\begin{array}{l}\text { Urban WWTP, serving } \\
320,000 \text { inhabitants } \\
\text { (Composite samples } \\
\text { collected from Dec } \\
\text { 2013-June 2014; ARG } \\
\text { concentration } \\
\text { estimates from figure } \\
4 \text { showing total ARG } \\
\text { abundance) }\end{array}$} & \multirow{8}{*}{$\begin{array}{c}\text { Shanghai, } \\
\text { China }\end{array}$} & 16S rRNA & $1.00 \mathrm{E}+04^{\text {bd }}$ & $2.50 \mathrm{E}+03$ & 0.602 & \\
\hline & & & ereA & $6.50 \mathrm{E}+03^{\mathrm{bd}}$ & $2.00 \mathrm{E}+03$ & 0.512 & \\
\hline & & & ereB & $8.00 \mathrm{E}+00^{\text {bd }}$ & $5.00 \mathrm{E}+00$ & 0.204 & \\
\hline & & & ermA & $3.00 \mathrm{E}-01^{\mathrm{bd}}$ & $3.10 \mathrm{E}-01$ & -0.014 & \\
\hline & & & ermB & $7.00 \mathrm{E}+02^{\mathrm{bd}}$ & $1.90 \mathrm{E}+02$ & 0.566 & \\
\hline & & & ermC & $4.00 \mathrm{E}-01^{\mathrm{bd}}$ & $4.50 \mathrm{E}-01$ & -0.051 & \\
\hline & & & $m e f \mathrm{~A} / m e f \mathrm{E}$ & $1.00 \mathrm{E}+02^{\mathrm{bd}}$ & $5.00 \mathrm{E}+01$ & 0.301 & \\
\hline & & & $m s r \mathrm{~A} / m s r \mathrm{~B}$ & $5.00 \mathrm{E}-01^{\mathrm{bd}}$ & 7.00E-01 & -0.146 & \\
\hline
\end{tabular}




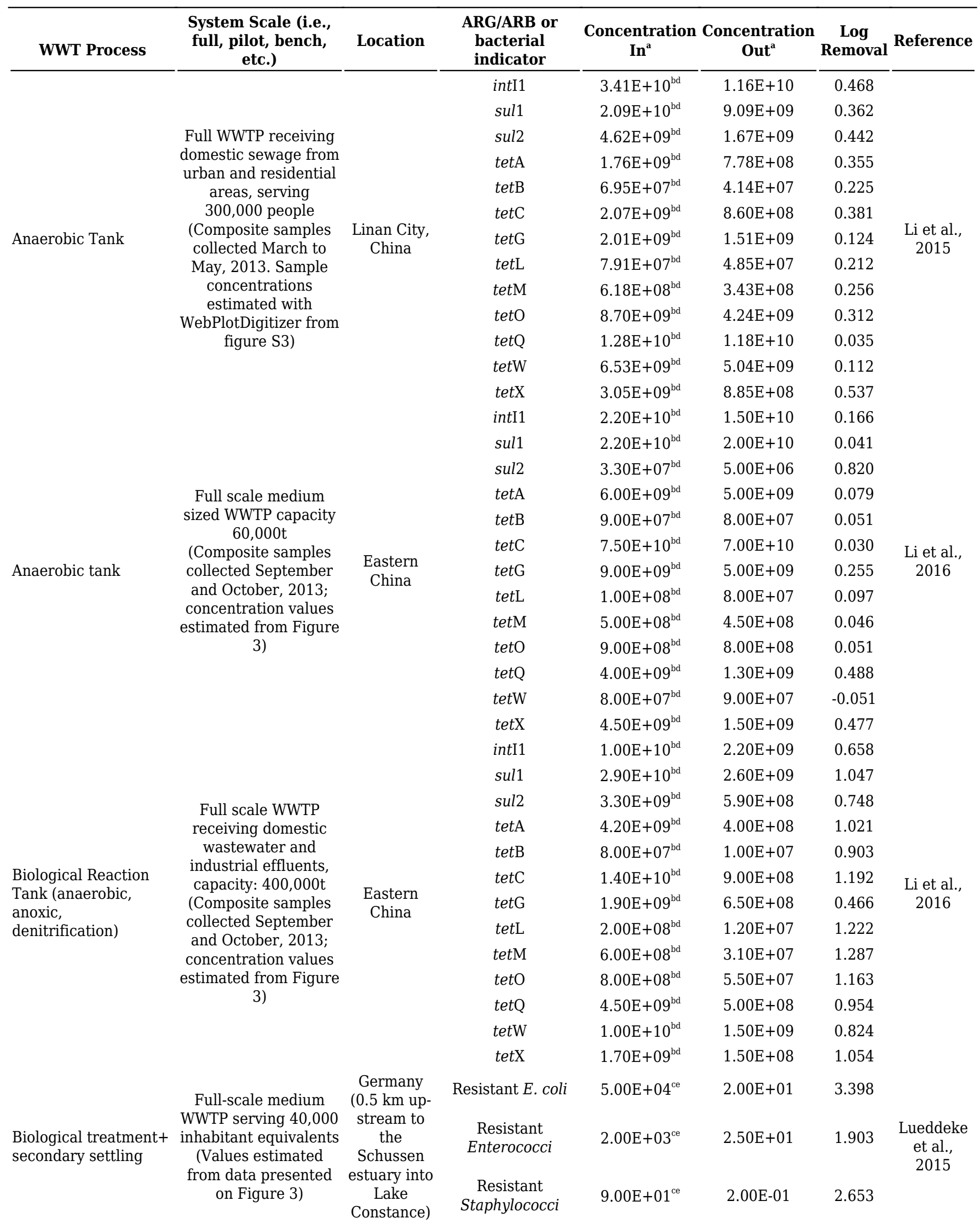




\begin{tabular}{|c|c|c|c|c|c|c|c|}
\hline WWT Process & $\begin{array}{l}\text { System Scale (i.e., } \\
\text { full, pilot, bench, } \\
\text { etc.) }\end{array}$ & Location & $\begin{array}{l}\text { ARG/ARB or } \\
\text { bacterial } \\
\text { indicator }\end{array}$ & $\begin{array}{c}\text { Concentration } \\
\operatorname{In}^{\mathbf{a}}\end{array}$ & $\begin{array}{c}\text { Concentration } \\
\text { Out }^{\mathrm{a}}\end{array}$ & $\begin{array}{c}\text { Log } \\
\text { Removal }\end{array}$ & Reference \\
\hline \multirow{3}{*}{$\begin{array}{l}\text { Anaerobic biological } \\
\text { treatment }\end{array}$} & $\begin{array}{l}\text { WWTP with } 60,000 \mathrm{~m}^{3} \\
\text { capacity and serving } \\
\text { about } 300,000 \\
\text { residents from urban } \\
\text { and residential areas. } \\
\text { WWTP configuration } \\
\text { consists of grid } \\
\text { screen, anaerobic } \\
\text { tank, oxidation ditch } \\
\text { (aerobic tank) and UV }\end{array}$ & & $\begin{array}{c}\text { ARB } \\
\text { (Sulfamethoxazole) } \\
\text { (R2A Agar }+50.4 \\
\text { mg/L } \\
\text { sulfamethoxazole) }\end{array}$ & $7.51 \mathrm{E}+05^{\mathrm{ce}}$ & $1.25 \mathrm{E}+06$ & 0.142 & \multirow{3}{*}{$\begin{array}{l}\text { Li et al., } \\
2015\end{array}$} \\
\hline & $\begin{array}{c}\text { disinfection plus } \\
\text { constructed wetland } \\
\text { systemprior to finally } \\
\text { discharging onto a } \\
\text { lake. } \\
\text { (Triplicate composite }\end{array}$ & $\begin{array}{l}\text { Linan City, } \\
\text { eastern } \\
\text { China }\end{array}$ & $\begin{array}{c}\text { ARB (Tetracycline) } \\
\text { (R2A Agar }+16 \\
\text { mg/L tetracycline) }\end{array}$ & $1.36 \mathrm{E}+05^{\mathrm{ce}}$ & $8.81 \mathrm{E}+04$ & 0.189 & \\
\hline & $\begin{array}{l}\text { samples were } \\
\text { collected over } 24 \text {-h } \\
\text { periods with } 3-\mathrm{h} \\
\text { intervals. Values } \\
\text { reported were } \\
\text { estimated from Figure } \\
\text { 2.) }\end{array}$ & & $\begin{array}{c}\text { ARB (Tetracycline } \\
+ \\
\text { Sulfamethoxazole) } \\
\text { (R2A Agar }+ \\
\text { tetracycline }+ \\
\text { sulfamethoxazole) }\end{array}$ & $6.58 \mathrm{E}+04^{\mathrm{ce}}$ & $3.68 \mathrm{E}+04$ & 0.252 & \\
\hline
\end{tabular}

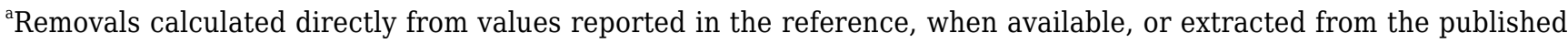
figures using WebPlotDigitizer or manually when this was not possible; ${ }^{\mathrm{b}} \mathrm{qPCR}$; ${ }^{\mathrm{c}}$ culture-based method; ${ }^{\mathrm{d}}$ gene copies/ $\mathrm{mL} ;{ }^{\mathrm{e}} \mathrm{Cfu} / \mathrm{mL}$

\subsubsection{Activated sludge}

Table 10. Activated sludge

\begin{tabular}{|c|c|c|c|c|c|c|c|}
\hline WWT Process & $\begin{array}{c}\text { System Scale } \\
\text { (i.e., full, } \\
\text { pilot, bench, } \\
\text { etc.) } \\
\end{array}$ & Location & $\begin{array}{l}\text { ARG/ARB } \\
\text { or } \\
\text { bacterial } \\
\text { indicator } \\
\end{array}$ & $\begin{array}{c}\text { Concentration } \\
\operatorname{In}^{\mathrm{a}, \mathrm{b}, \mathrm{c}} \\
\end{array}$ & $\begin{array}{c}\text { Concentration } \\
\text { Out }^{\mathrm{a}, \mathrm{b}, \mathrm{c}}\end{array}$ & $\begin{array}{c}\text { Log } \\
\text { Removal }\end{array}$ & Reference \\
\hline \multirow{9}{*}{$\begin{array}{l}\text { Biological treatment } \\
\text { (activated sludge) }\end{array}$} & $\begin{array}{c}\text { Full scale, large } \\
\text { municipal }\end{array}$ & \multirow{9}{*}{$\begin{array}{l}\text { Verbania, } \\
\text { Italy }\end{array}$} & $\operatorname{arsB}$ & $1.74 \mathrm{E}+05$ & $1.86 \mathrm{E}+04$ & 0.971 & \multirow{9}{*}{$\begin{array}{l}\text { Di Cesare } \\
\text { et al., } \\
2015\end{array}$} \\
\hline & $\begin{array}{c}\text { WWTP } \\
\text { receiving }\end{array}$ & & blaCTX-M & $4.79 \mathrm{E}+02$ & $<\mathrm{LOQ}$ & $\leq 2.68^{*}$ & \\
\hline & $\begin{array}{c}\text { domestic } \\
\text { sewage and }\end{array}$ & & blaTEM & $4.79 \mathrm{E}+03$ & $<\mathrm{LOQ}$ & $\leq 3.68^{*}$ & \\
\hline & $\begin{array}{l}\text { pretreated } \\
\text { hospital }\end{array}$ & & $c z c \mathrm{~A}$ & $1.16 \mathrm{E}+04$ & $9.04 \mathrm{E}+02$ & 1.108 & \\
\hline & $\begin{array}{c}\text { sewage. } \\
\text { (Grab samples }\end{array}$ & & ermB & $8.50 \mathrm{E}+04$ & $3.14 \mathrm{E}+03$ & 1.432 & \\
\hline & $\begin{array}{l}\text { collected July } \\
\text { 2nd, } 2015 .\end{array}$ & & intI1 & $1.21 \mathrm{E}+05$ & $3.42 \mathrm{E}+03$ & 1.549 & \\
\hline & $\begin{array}{l}\text { Mean and } \\
\text { standard }\end{array}$ & & $q n r S$ & $4.67 \mathrm{E}+05$ & $9.59 \mathrm{E}+03$ & 1.687 & \\
\hline & $\begin{array}{l}\text { deviation values } \\
\text { of absolute }\end{array}$ & & sul2 & $5.69 \mathrm{E}+04$ & $5.44 \mathrm{E}+03$ & 1.020 & \\
\hline & $\begin{array}{c}\text { abundance from } \\
\text { Table S2.) }\end{array}$ & & tetA & $5.05 E+04$ & $1.16 \mathrm{E}+03$ & 1.639 & \\
\hline
\end{tabular}




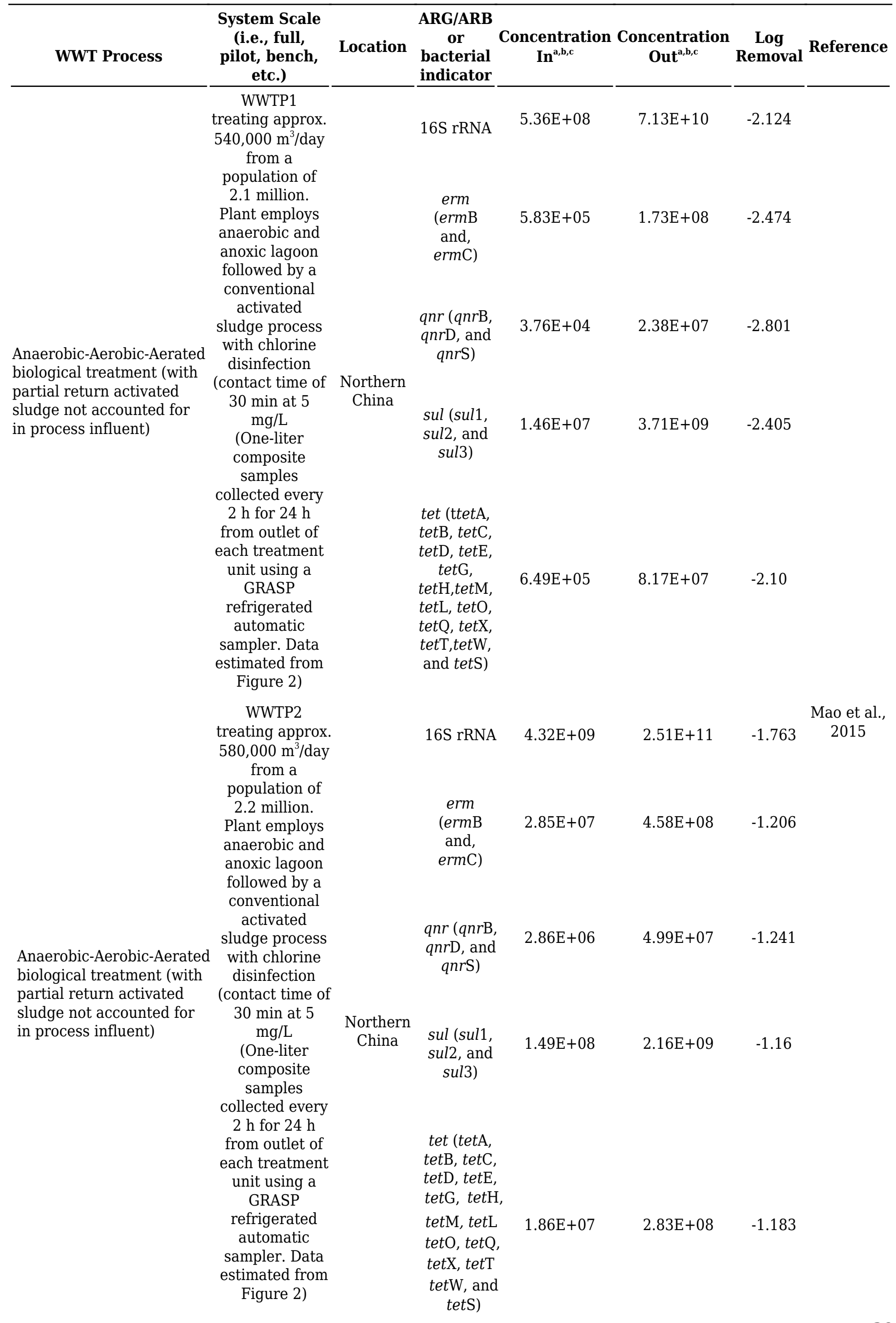




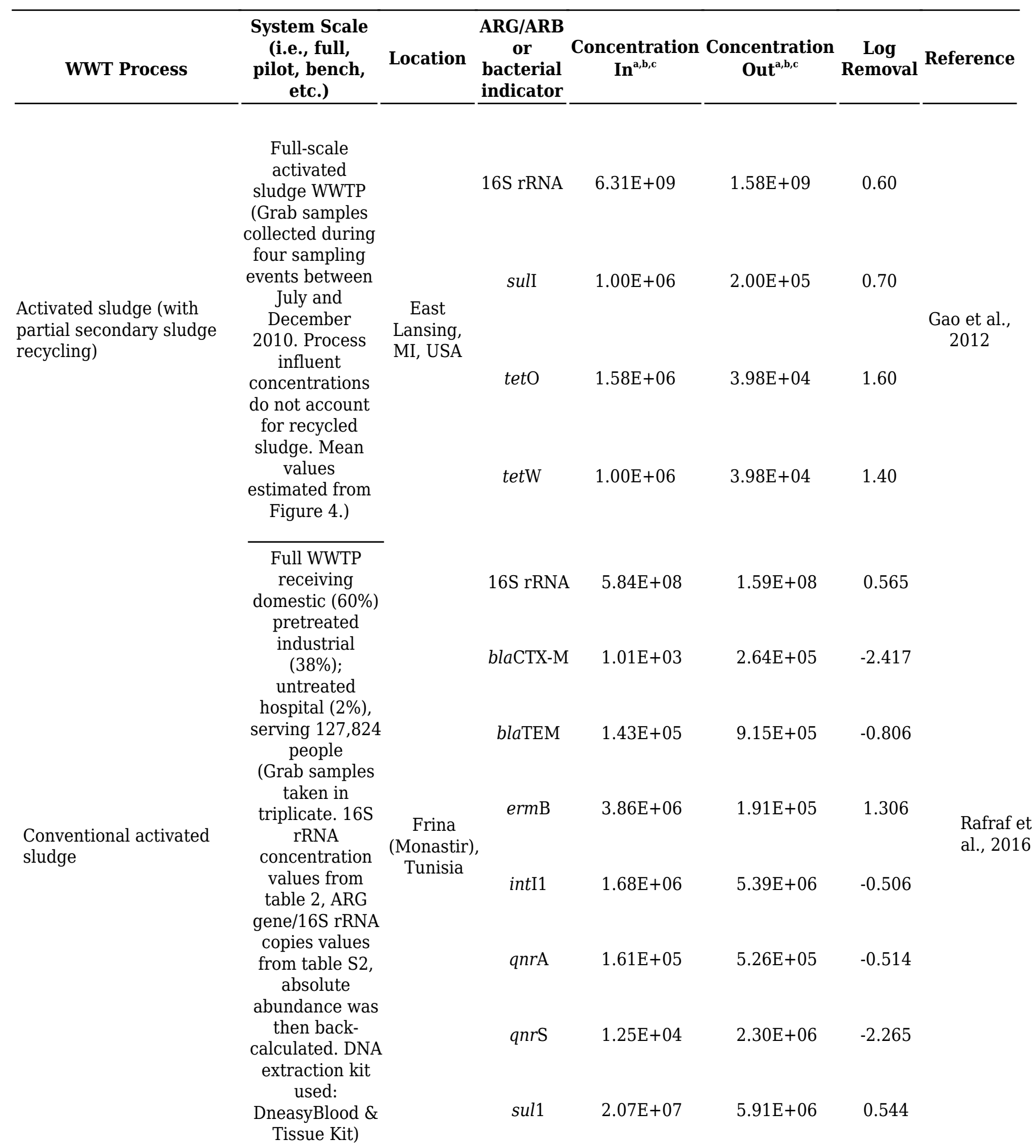




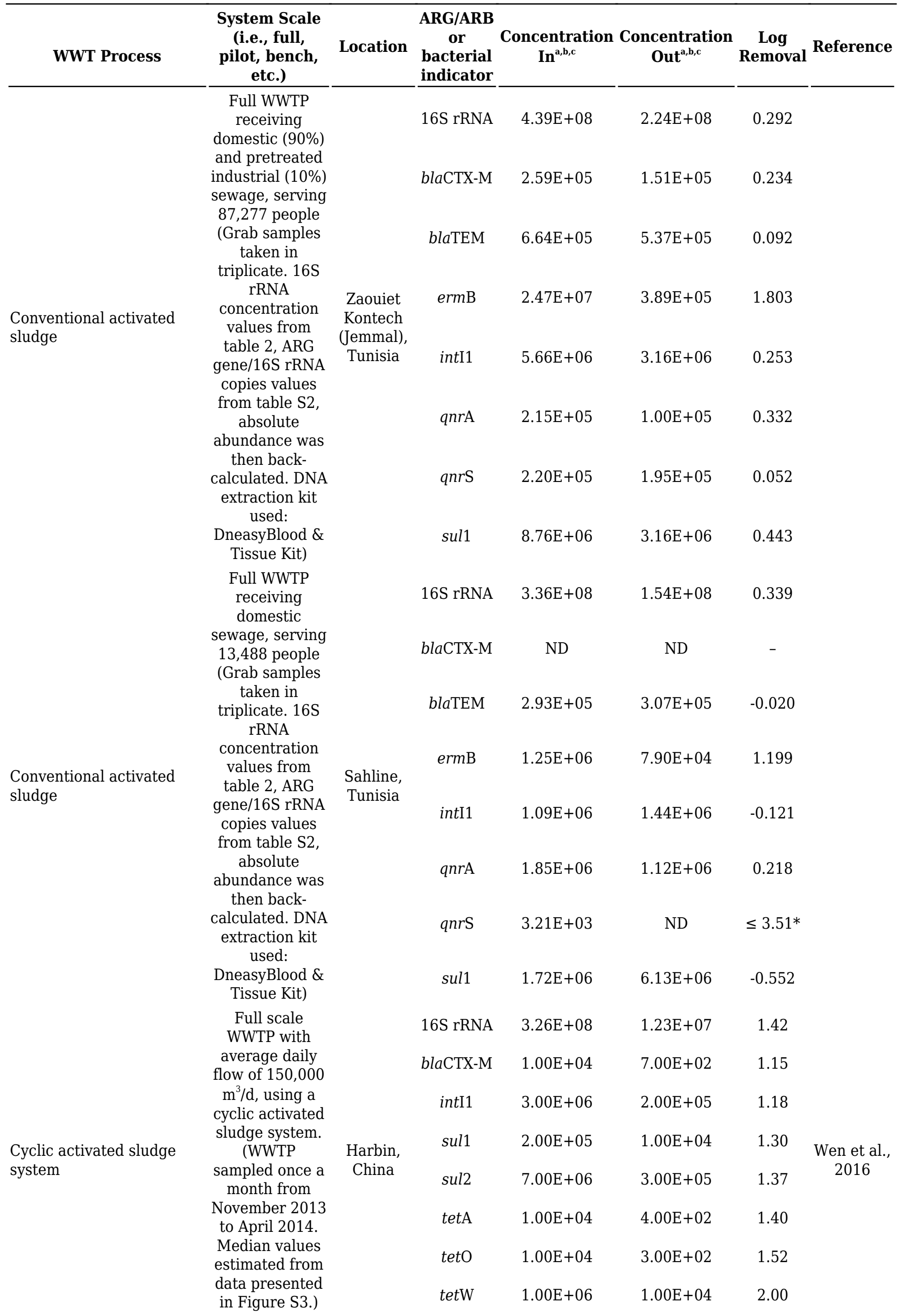




\begin{tabular}{|c|c|c|c|c|c|c|c|}
\hline WWT Process & $\begin{array}{l}\text { System Scale } \\
\text { (i.e., full, } \\
\text { pilot, bench, } \\
\text { etc.) }\end{array}$ & Location & $\begin{array}{c}\text { ARG/ARB } \\
\text { or } \\
\text { bacterial } \\
\text { indicator } \\
\end{array}$ & $\begin{array}{c}\text { Concentration } \\
\operatorname{In}^{\mathrm{a}, \mathrm{b}, \mathrm{c}} \\
\end{array}$ & $\begin{array}{c}\text { Concentration } \\
\text { Out }^{\mathrm{a}, \mathrm{b}, \mathrm{c}}\end{array}$ & $\begin{array}{c}\text { Log } \\
\text { Removal }\end{array}$ & Reference \\
\hline \multirow{3}{*}{$\begin{array}{l}\text { Activated Sludge (prior to } \\
\text { secondary sedimentation) }\end{array}$} & $\begin{array}{l}\text { WWTP treating } \\
\text { domestic } \\
\text { wastewater }\end{array}$ & & intI1 & $2.04 \mathrm{E}+07$ & $2.49 \mathrm{E}+09$ & -2.087 & \multirow{3}{*}{$\begin{array}{l}\text { Zhang et } \\
\text { al., } 2009\end{array}$} \\
\hline & $\begin{array}{c}\text { from population } \\
\text { of about } \\
\text { 100,000. Daily } \\
\text { average flow }\end{array}$ & $\begin{array}{c}\text { Nanjing, } \\
\text { China; } \\
\text { April 2008 }\end{array}$ & tetA & $4.96 \mathrm{E}+07$ & $4.23 E+09$ & -1.931 & \\
\hline & $\begin{array}{c}\text { rate: } 15,000 \mathrm{~m}^{3} . \\
\text { (Values } \\
\text { extracted from } \\
\text { Table 3) }\end{array}$ & & tetC & $8.06 \mathrm{E}+07$ & $4.56 \mathrm{E}+09$ & -1.753 & \\
\hline \multirow{3}{*}{$\begin{array}{l}\text { Activated Sludge (prior to } \\
\text { secondary settling) }\end{array}$} & $\begin{array}{c}\text { Domestic } \\
\text { WWTP with } \\
\text { average daily }\end{array}$ & \multirow{3}{*}{$\begin{array}{l}\text { Hong } \\
\text { Kong }\end{array}$} & tetA & $6.00 \mathrm{E}+07$ & $2.60 \mathrm{E}+07$ & 0.363 & \multirow{7}{*}{$\begin{array}{l}\text { Zhang et } \\
\text { al., } 2009\end{array}$} \\
\hline & $\begin{array}{c}\text { flow of } 150,000 \\
m^{3} \text { serving }\end{array}$ & & & & & & \\
\hline & $\begin{array}{l}\text { population of } \\
\text { about } 370,000 \\
\text { (Data extracted } \\
\text { from Table 3) }\end{array}$ & & tetC & $1.35 \mathrm{E}+08$ & $6.70 \mathrm{E}+07$ & 0.304 & \\
\hline \multirow{4}{*}{$\begin{array}{l}\text { Activated Sludge (prior to } \\
\text { secondary settling) }\end{array}$} & Domestic & \multirow{4}{*}{$\begin{array}{l}\text { Hong } \\
\text { Kong }\end{array}$} & & & & & \\
\hline & & & tetA & $1.59 \mathrm{E}+08$ & $2.19 \mathrm{E}+08$ & -0.139 & \\
\hline & $\begin{array}{c}\text { flow rate of } \\
8478 \mathrm{~m}^{3} \text { serving }\end{array}$ & & & & & & \\
\hline & $\begin{array}{l}\text { population of } \\
\text { about } 19,000 \\
\text { (Data extracted } \\
\text { from Table 3) }\end{array}$ & & tetC & $1.90 \mathrm{E}+08$ & $8.06 \mathrm{E}+08$ & -0.628 & \\
\hline \multirow{8}{*}{$\begin{array}{l}\text { Activated sludge WWTP } \\
\text { with UV disinfection }\end{array}$} & $\begin{array}{c}\text { Full WWTP } \\
\text { receiving } \\
\text { domestic }\end{array}$ & \multirow{8}{*}{$\begin{array}{l}\text { Beni } \\
\text { Hassen, } \\
\text { Tunisia }\end{array}$} & 16S rRNA & $2.22 \mathrm{E}+08$ & $1.43 E+08$ & 0.191 & \multirow{8}{*}{$\begin{array}{l}\text { Rafraf et } \\
\text { al., } 2016\end{array}$} \\
\hline & $\begin{array}{l}\text { sewage, serving } \\
\text { 16,358 people } \\
\text { (Grab samples }\end{array}$ & & blaCTX-M & ND & ND & & \\
\hline & $\begin{array}{c}\text { taken in } \\
\text { triplicate. 16S } \\
\text { rRNA }\end{array}$ & & blaTEM & $4.53 \mathrm{E}+04$ & $3.94 \mathrm{E}+05$ & -0.939 & \\
\hline & $\begin{array}{l}\text { concentration } \\
\text { values from } \\
\text { table } 2 \text {, ARG }\end{array}$ & & ermB & $1.09 \mathrm{E}+06$ & $1.27 \mathrm{E}+05$ & 0.934 & \\
\hline & $\begin{array}{c}\text { gene/16S rRNA } \\
\text { copies values } \\
\text { from table S2, }\end{array}$ & & intI1 & $2.73 E+06$ & $2.37 \mathrm{E}+06$ & 0.061 & \\
\hline & $\begin{array}{c}\text { absolute } \\
\text { abundance was } \\
\text { then back- }\end{array}$ & & qnrA & $3.44 \mathrm{E}+05$ & $1.89 \mathrm{E}+06$ & -0.740 & \\
\hline & $\begin{array}{c}\text { calculated. DNA } \\
\text { extraction kit } \\
\text { used: }\end{array}$ & & qnrS & $3.28 \mathrm{E}+03$ & ND & & \\
\hline & $\begin{array}{c}\text { DneasyBlood \& } \\
\text { Tissue Kit) }\end{array}$ & & sul1 & $2.99 \mathrm{E}+06$ & $2.79 \mathrm{E}+06$ & 0.030 & \\
\hline
\end{tabular}




\begin{tabular}{|c|c|c|c|c|c|c|c|}
\hline WWT Process & $\begin{array}{c}\text { System Scale } \\
\text { (i.e., full, } \\
\text { pilot, bench, } \\
\text { etc.) } \\
\end{array}$ & Location & $\begin{array}{c}\text { ARG/ARB } \\
\text { or } \\
\text { bacterial } \\
\text { indicator } \\
\end{array}$ & $\begin{array}{c}\text { Concentration } \\
\text { In }^{\mathrm{a}, \mathrm{b}, \mathrm{c}}\end{array}$ & $\begin{array}{c}\text { Concentration } \\
\text { Out }^{\mathrm{a}, \mathrm{b}, \mathrm{c}}\end{array}$ & $\begin{array}{c}\text { Log } \\
\text { Removal }\end{array}$ & Reference \\
\hline \multirow{9}{*}{$\begin{array}{l}\text { Sedimentation tank and } \\
\text { biological (activated } \\
\text { sludge) treatment and } \\
\text { chemical (aluminum } \\
\text { polychloride enriched by } \\
\text { sodium hydroxide) } \\
\text { treatment }\end{array}$} & Full scale, small & \multirow{9}{*}{$\begin{array}{l}\text { Cannobio, } \\
\text { Italy }\end{array}$} & $\operatorname{ars} \mathrm{B}$ & $2.63 E+05$ & $3.82 \mathrm{E}+04$ & 0.838 & \multirow{9}{*}{$\begin{array}{l}\text { Di Cesare } \\
\text { et al., } \\
2015\end{array}$} \\
\hline & WWTP & & blaCTX-M & $1.91 \mathrm{E}+03$ & N/A & $\leq 3.28^{*}$ & \\
\hline & $\begin{array}{l}\text { receiving } \\
\text { domestic }\end{array}$ & & blaTEM & $1.63 \mathrm{E}+04$ & N/A & $\leq 4.21 *$ & \\
\hline & sewage & & $c z c \mathrm{~A}$ & $1.59 \mathrm{E}+04$ & $7.25 \mathrm{E}+02$ & 1.341 & \\
\hline & collected July & & ermB & $6.71 \mathrm{E}+05$ & $1.21 \mathrm{E}+03$ & 2.744 & \\
\hline & & & intI1 & $2.93 E+05$ & $6.43 E+03$ & 1.659 & \\
\hline & & & qnrS & $7.93 \mathrm{E}+05$ & $5.10 \mathrm{E}+02$ & 3.192 & \\
\hline & $\begin{array}{c}\text { of absolute } \\
\text { abundance from }\end{array}$ & & sul2 & $1.78 \mathrm{E}+05$ & $2.49 \mathrm{E}+03$ & 1.854 & \\
\hline & Table S2.) & & tetA & $1.39 \mathrm{E}+05$ & $7.06 \mathrm{E}+02$ & 2.294 & \\
\hline \multirow{9}{*}{$\begin{array}{l}\text { Sedimentation tank and } \\
\text { combined biological } \\
\text { (activated sludge) and } \\
\text { chemical (aluminum } \\
\text { polychloride) treatment }\end{array}$} & $\begin{array}{c}\text { Full scale, large } \\
\text { municipal }\end{array}$ & \multirow{9}{*}{$\begin{array}{l}\text { Novara, } \\
\text { Italy }\end{array}$} & $\operatorname{arsB}$ & $1.10 \mathrm{E}+06$ & $7.98 \mathrm{E}+04$ & 1.139 & \multirow{9}{*}{$\begin{array}{l}\text { Di Cesare } \\
\text { et al., } \\
2015\end{array}$} \\
\hline & $\begin{array}{l}\text { WWTP } \\
\text { receiving }\end{array}$ & & blaCTX-M & $4.55 \mathrm{E}+04$ & $<\mathrm{LOQ}$ & $\leq 4.55^{*}$ & \\
\hline & domestic & & blaTEM & $6.66 \mathrm{E}+04$ & $<\mathrm{LOQ}$ & $\leq 4.82^{*}$ & \\
\hline & pretreated & & $c z c \mathrm{~A}$ & 8.39E+04 & $3.76 \mathrm{E}+03$ & 1.349 & \\
\hline & $\begin{array}{c}\text { hospital sewage } \\
\text { (Grab samples } \\
\text { collected July }\end{array}$ & & ermB & $4.62 \mathrm{E}+06$ & $4.05 E+03$ & 3.057 & \\
\hline & 8th, 2015. & & intI1 & $9.79 \mathrm{E}+05$ & $1.45 \mathrm{E}+03$ & 2.829 & \\
\hline & $\begin{array}{l}\text { Mean and } \\
\text { standard }\end{array}$ & & $q n r S$ & $5.98 \mathrm{E}+06$ & $1.14 \mathrm{E}+04$ & 2.720 & \\
\hline & $\begin{array}{l}\text { deviation values } \\
\text { of absolute }\end{array}$ & & sul2 & $7.10 \mathrm{E}+05$ & $1.68 \mathrm{E}+04$ & 1.626 & \\
\hline & $\begin{array}{c}\text { abundance from } \\
\text { Table S2.) }\end{array}$ & & tetA & $5.57 \mathrm{E}+05$ & $2.28 \mathrm{E}+03$ & 2.388 & \\
\hline
\end{tabular}

${ }^{\text {a }}$ Removals calculated directly from values reported in the reference, when available, or extracted from the published figures using WebPlotDigitizer or manually when this was not possible; ${ }^{\mathrm{b}} \mathrm{qPCR}$; ${ }^{\mathrm{c}}$ culture-based method; ${ }^{\mathrm{d}}$ gene copies/ $\mathrm{mL} ;{ }^{\mathrm{e}} \mathrm{cfu} / \mathrm{mL}$; - not reported; *values calculated using 1 gene copy/mL as the value for ND, NA or < LOQ; ND = not detected 
Table 11. Full treatment

\begin{tabular}{|c|c|c|c|c|c|c|c|}
\hline WWT Process & $\begin{array}{c}\text { System Scale (i.e., } \\
\text { full, pilot, bench, } \\
\text { etc.) }\end{array}$ & Location & $\begin{array}{c}\text { ARG/ARB or } \\
\text { bacterial } \\
\text { indicator } \\
\end{array}$ & $\underset{\text { In }^{\mathrm{a}}}{\text { Concentration }}$ & $\begin{array}{c}\text { Concentration } \\
\text { Out }^{\mathrm{a}}\end{array}$ & $\begin{array}{c}\log \\
\text { Removal }\end{array}$ & Reference \\
\hline \multirow{6}{*}{ Full WWTP } & \multirow{6}{*}{$\begin{array}{l}\text { Full scale activated } \\
\text { sludge WWTP A } \\
\text { (ARG abundance } \\
\text { means estimated } \\
\text { from Figure 1.) }\end{array}$} & $\begin{array}{l}\text { Wisconsin, } \\
\text { USA; March }\end{array}$ & tet $\mathrm{G}$ & $1.50 \mathrm{E}+07^{\mathrm{bd}}$ & $1.50 \mathrm{E}+05$ & 2.00 & \multirow{6}{*}{$\begin{array}{l}\text { Auerbach } \\
\text { et al., } \\
2007\end{array}$} \\
\hline & & $\begin{array}{l}\text { Wisconsin, } \\
\text { USA; July }\end{array}$ & tet $\mathrm{G}$ & $2.00 \mathrm{E}+06^{\mathrm{bd}}$ & $1.50 \mathrm{E}+04$ & 2.12 & \\
\hline & & $\begin{array}{l}\text { Wisconsin, } \\
\text { USA; } \\
\text { November }\end{array}$ & tet $\mathrm{G}$ & $7.00 \mathrm{E}+07^{\mathrm{bd}}$ & $8.00 \mathrm{E}+05$ & 1.94 & \\
\hline & & $\begin{array}{l}\text { Wisconsin, } \\
\text { USA; March }\end{array}$ & tetQ & $9.00 \mathrm{E}+08^{\mathrm{bd}}$ & $6.00 \mathrm{E}+05$ & 3.18 & \\
\hline & & $\begin{array}{l}\text { Wisconsin, } \\
\text { USA; July }\end{array}$ & tetQ & $1.50 \mathrm{E}+07^{\mathrm{bd}}$ & $8.00 \mathrm{E}+03$ & 3.27 & \\
\hline & & $\begin{array}{l}\text { Wisconsin, } \\
\text { USA; } \\
\text { November }\end{array}$ & tetQ & $6.00 \mathrm{E}+08^{\mathrm{bd}}$ & $2.00 \mathrm{E}+05$ & 3.48 & \\
\hline \multirow{2}{*}{ Full WWTP } & $\begin{array}{l}\text { Full scale activated } \\
\text { sludge WWTP B } \\
\text { (ARG abundance }\end{array}$ & \multirow{2}{*}{$\begin{array}{l}\text { Wisconsin, } \\
\text { USA; March }\end{array}$} & tet $\mathrm{G}$ & $1.00 \mathrm{E}+07^{\text {bd }}$ & $3.00 \mathrm{E}+05$ & 1.52 & \multirow[b]{3}{*}{$\begin{array}{l}\text { Borjesson } \\
\text { et al., } \\
2009\end{array}$} \\
\hline & $\begin{array}{l}\text { means estimated } \\
\text { from Figure 1.) }\end{array}$ & & tetQ & $2.50 \mathrm{E}+08^{\mathrm{bd}}$ & $1.50 \mathrm{E}+06$ & 2.22 & \\
\hline Full WWTP & $\begin{array}{c}\text { Large full scale } \\
\text { WWTP designed for } \\
\text { biological nitrogen } \\
\text { removal } \\
\text { (Median ARG } \\
\text { abundance values } \\
\text { from samples } \\
\text { collected monthly } \\
\text { over a year were } \\
\text { estimated from } \\
\text { Figure } 2 . \text { Inlet temp } \\
14 \pm 3.3^{\circ} \mathrm{C} \text {. Outlet } \\
\text { temp } 14 \pm 4.2^{\circ} \mathrm{C} \text {.) }\end{array}$ & $\begin{array}{c}\text { Gothenburg, } \\
\text { Sweden }\end{array}$ & mecA & $4.00 \mathrm{E}+01^{\mathrm{bd}}$ & $2.00 \mathrm{E}+00$ & 1.30 & \\
\hline Full WWTP & $\begin{array}{l}\text { Full scale serving } \\
214,000 \text { people, } \\
\text { receiving domestic } \\
\text { waste and } \\
\text { wastewater from } \\
\text { health care centers } \\
\text { (Samples collected } \\
\text { between February, } \\
\text { 2010. Samples not } \\
\text { extracted with Kit } \\
\text { (GOS buffer followed } \\
\text { by freezing in liquid } \\
\text { nitrogen, thawing, } \\
\text { centrifugation etc.). } \\
\text { Values estimated } \\
\text { from Figure 3.) }\end{array}$ & $\begin{array}{l}\text { Lausanne, } \\
\text { Switzerland }\end{array}$ & 16S rRNA & $1.93 \mathrm{E}+06^{\mathrm{bd}}$ & $2.91 \mathrm{E}+06$ & -0.178 & $\begin{array}{l}\text { Czekalski } \\
\text { et al., } \\
2012\end{array}$ \\
\hline \multirow{5}{*}{$\begin{array}{l}\text { Full WWTP } \\
\text { (anaerobic/anoxic/aerobic-membrane } \\
\text { bioreactor) }\end{array}$} & \multirow{5}{*}{$\begin{array}{c}\text { Full scale, } 56 \% \\
\text { industrial and } 44 \% \\
\text { domestic waste } \\
\text { (Composite samples } \\
\text { collected from Nov } \\
\text { 6th - 15th, 2012. 16S } \\
\text { not reported. Values } \\
\text { from Table 4.) }\end{array}$} & \multirow{5}{*}{ Wuxi, China } & intl1 & $1.32 \mathrm{E}+07^{\mathrm{bd}}$ & $9.33 \mathrm{E}+04$ & 2.151 & \multirow{10}{*}{$\begin{array}{l}\text { Du et al., } \\
2014\end{array}$} \\
\hline & & & sul1 & $1.10 \mathrm{E}+07^{\mathrm{bd}}$ & $9.33 \mathrm{E}+04$ & 2.072 & \\
\hline & & & tet $\mathrm{G}$ & $3.89 \mathrm{E}+05^{\mathrm{bd}}$ & $2.45 \mathrm{E}+03$ & 2.201 & \\
\hline & & & tet $\mathrm{W}$ & $5.62 \mathrm{E}+05^{\mathrm{bd}}$ & $7.08 \mathrm{E}+02$ & 2.900 & \\
\hline & & & tetX & $1.95 \mathrm{E}+06^{\mathrm{bd}}$ & $3.89 \mathrm{E}+04$ & 1.700 & \\
\hline \multirow{5}{*}{$\begin{array}{l}\text { Full WWTP with anaerobic/aerobic } \\
\text { treatment }\end{array}$} & \multirow{5}{*}{$\begin{array}{l}\text { Full scale, Domestic } \\
\quad \text { wastewater } \\
\text { (Composite samples } \\
\text { collected from Nov } \\
\text { 6th - 15th, 2012.16S } \\
\text { not reported. Values } \\
\text { from Table 4.) }\end{array}$} & \multirow{5}{*}{$\begin{array}{l}\text { Nanjing, } \\
\text { China }\end{array}$} & intl1 & $7.41 \mathrm{E}+06^{\mathrm{bd}}$ & $8.71 \mathrm{E}+04$ & 1.930 & \\
\hline & & & sul1 & $7.76 \mathrm{E}+06^{\mathrm{bd}}$ & $1.00 \mathrm{E}+05$ & 1.890 & \\
\hline & & & tet $\mathrm{G}$ & $4.37 \mathrm{E}+05^{\mathrm{bd}}$ & $5.13 E+03$ & 1.930 & \\
\hline & & & tet $\mathrm{W}$ & $3.09 \mathrm{E}+05^{\mathrm{bd}}$ & $1.02 \mathrm{E}+03$ & 2.481 & \\
\hline & & & tet $\mathrm{X}$ & $1.38 \mathrm{E}+06^{\mathrm{bd}}$ & $5.62 \mathrm{E}+04$ & 1.390 & \\
\hline
\end{tabular}




\begin{tabular}{|c|c|c|c|c|c|c|c|}
\hline WWT Process & $\begin{array}{l}\text { System Scale (i.e., } \\
\text { full, pilot, bench, } \\
\text { etc.) }\end{array}$ & Location & $\begin{array}{l}\text { ARG/ARB or } \\
\text { bacterial } \\
\text { indicator }\end{array}$ & $\begin{array}{c}\text { Concentration } \\
\text { In }^{\mathrm{a}}\end{array}$ & $\begin{array}{c}\text { Concentration } \\
\text { Out }^{\mathrm{a}}\end{array}$ & $\begin{array}{c}\text { Log } \\
\text { Removal }\end{array}$ & Reference \\
\hline \multirow{5}{*}{$\begin{array}{l}\text { Full-WWTP } \\
\text { (anaerobic/anoxic/aerobic-membrane } \\
\text { bioreactor) }\end{array}$} & $\begin{array}{l}\text { Full scale WWTP } \\
\text { receiving domestic } \\
\text { wastewater }(44 \%)\end{array}$ & & intl1 & $7.48 \mathrm{E}+06^{\mathrm{bd}}$ & $1.82 \mathrm{E}+05$ & 1.614 & \multirow{5}{*}{$\begin{array}{c}\text { Du et al., } \\
2015\end{array}$} \\
\hline & $\begin{array}{l}\text { and pre-treated } \\
\text { industrial }\end{array}$ & & sul1 & $5.28 \mathrm{E}+07^{\mathrm{bd}}$ & $4.27 \mathrm{E}+05$ & 2.092 & \\
\hline & $\begin{array}{l}\text { wastewater (56\%) } \\
\text { (Composite samples } \\
\text { collected October } \\
2012 \text { to September } \\
2013 \text { (except for }\end{array}$ & $\begin{array}{l}\text { Wuxi, } \\
\text { Jiangsu } \\
\text { Province, } \\
\text { China }\end{array}$ & tet $\mathrm{G}$ & $4.67 \mathrm{E}+05^{\text {bd }}$ & $8.51 \mathrm{E}+04$ & 0.739 & \\
\hline & $\begin{array}{l}\text { February 2013); } \\
\text { average values }\end{array}$ & & tetw & $8.69 \mathrm{E}+05^{\mathrm{bd}}$ & $1.84 \mathrm{E}+03$ & 2.674 & \\
\hline & $\begin{array}{l}\text { reported from the } \\
\text { range reported in } \\
\text { table 4) }\end{array}$ & & tetX & $2.84 \mathrm{E}+06^{\mathrm{bd}}$ & $2.52 \mathrm{E}+04$ & 2.052 & \\
\hline \multirow{7}{*}{ Full WWTP } & $\begin{array}{c}\text { Secondary } \\
\text { mechanical-biological } \\
\text { treatment plant }\end{array}$ & & 16S rRNA & $4.60 \mathrm{E}+08^{\mathrm{bd}}$ & $4.50 \mathrm{E}+05$ & 3.010 & \multirow{7}{*}{$\begin{array}{l}\text { Makowska } \\
\text { et al., } \\
2016\end{array}$} \\
\hline & $\begin{array}{l}\text { serving } \sim 120,000 \\
\text { population. No } \\
\text { disinfection. The }\end{array}$ & & intI1 & $2.30 \mathrm{E}+04^{\mathrm{bd}}$ & $2.10 \mathrm{E}+03$ & 1.040 & \\
\hline & WWTP collects about & & sul1 & $7.60 \mathrm{E}+04^{\mathrm{bd}}$ & $1.50 \mathrm{E}+04$ & 0.705 & \\
\hline & $\begin{array}{c}55,000 \mathrm{~m}^{3} \text { of } \\
\text { wastewater from } \\
\text { households (70\%), } \\
\text { industry }(10 \%) \text {, and }\end{array}$ & Poland & sul2 & $2.60 \mathrm{E}+04^{\mathrm{bd}}$ & $6.20 \mathrm{E}+03$ & 0.623 & \\
\hline & & & tetA & $1.60 \mathrm{E}+03^{\mathrm{bd}}$ & $3.50 \mathrm{E}+02$ & 0.660 & \\
\hline & $\begin{array}{c}\text { four times, } \\
\text { seasonally, on } \\
\text { December 2013, and }\end{array}$ & & tetB & $1.90 \mathrm{E}+03^{\mathrm{bd}}$ & $1.80 \mathrm{E}+01$ & 2.023 & \\
\hline & $\begin{array}{l}\text { February, May and } \\
\text { July 2014.) }\end{array}$ & & tet $\mathrm{M}$ & $1.00 \mathrm{E}+03^{\mathrm{bd}}$ & $2.50 \mathrm{E}+01$ & 1.602 & \\
\hline \multirow{3}{*}{ Full WWTP } & $\begin{array}{l}\text { WWTP treating } \\
\text { domestic wastewater } \\
\text { from population of }\end{array}$ & & intI1 & $2.04 \mathrm{E}+07^{\mathrm{bd}}$ & $1.20 \mathrm{E}+06$ & 1.230 & \multirow{3}{*}{$\begin{array}{l}\text { Zhang et } \\
\text { al., } 2009\end{array}$} \\
\hline & $\begin{array}{c}\text { about } 100,000 \text {. Daily } \\
\text { average flow rate: } \\
15,000 \mathrm{~m}^{3} .\end{array}$ & $\begin{array}{l}\text { Nanjing, } \\
\text { China; April } \\
\text { 2008 }\end{array}$ & tetA & $4.96 \mathrm{E}+07^{\mathrm{bd}}$ & $1.41 \mathrm{E}+06$ & 1.546 & \\
\hline & $\begin{array}{l}\text { (Values extracted } \\
\text { from Table 3) }\end{array}$ & & tetC & $8.06 \mathrm{E}+07^{\mathrm{bd}}$ & $1.37 \mathrm{E}+06$ & 1.770 & \\
\hline Full WWTP & $\begin{array}{l}\text { Full scale treating } \\
\text { municipal waste, } \\
\text { average processing } \\
\text { capacity of } 60,000 \\
\mathrm{~m}^{3} / \text { day; includes } \\
\text { mechanical, } \\
\text { biological, and } \\
\text { chemical treatment } \\
\text { (Samples collected } \\
\text { January, April, July, } \\
\text { and October 2015. } \\
\text { Values from Table 1.) }\end{array}$ & $\begin{array}{l}\text { Olsztyn, } \\
\text { Poland }\end{array}$ & $\begin{array}{l}\text { amoxicillin } \\
\text { resistant } \\
\text { Escherichia coli. }\end{array}$ & $6.40 \mathrm{E}+04^{\mathrm{ce}}$ & $9.10 \mathrm{E}+02$ & 1.847 & \multirow{3}{*}{$\begin{array}{l}\text { Osinska et } \\
\text { al., } 2017\end{array}$} \\
\hline Full WWTP & $\begin{array}{l}\text { Full scale treating } \\
\text { municipal waste, } \\
\text { average processing } \\
\text { capacity of } 60,000 \\
\mathrm{~m}^{3} / \text { day; includes } \\
\text { mechanical, } \\
\text { biological, and } \\
\text { chemical treatment } \\
\text { (Samples collected } \\
\text { January, April, July, } \\
\text { and October 2015. } \\
\text { Values from Table 1.) }\end{array}$ & $\begin{array}{l}\text { Olsztyn, } \\
\text { Poland }\end{array}$ & $\begin{array}{l}\text { tetracycline } \\
\text { resistant } \\
\text { Escherichia coli. }\end{array}$ & $4.21 \mathrm{E}+04^{\mathrm{ce}}$ & $1.20 \mathrm{E}+02$ & 2.545 & \\
\hline Full WWTP & $\begin{array}{l}\text { Full scale treating } \\
\text { municipal waste, } \\
\text { average processing } \\
\text { capacity of } 60,000 \\
\mathrm{~m}^{3} / \text { day; includes } \\
\text { mechanical, } \\
\text { biological, and } \\
\text { chemical treatment } \\
\text { (Samples collected } \\
\text { January, April, July, } \\
\text { and October 2015. } \\
\text { Values from Table 1.) }\end{array}$ & $\begin{array}{l}\text { Olsztyn, } \\
\text { Poland }\end{array}$ & $\begin{array}{l}\text { ciprofloxacin } \\
\text { resistant } \\
\text { Escherichia coli. }\end{array}$ & $3.10 \mathrm{E}+03^{\mathrm{ce}}$ & $7.50 \mathrm{E}+01$ & 1.616 & \\
\hline
\end{tabular}




\begin{tabular}{|c|c|c|c|c|c|c|c|}
\hline WWT Process & $\begin{array}{c}\text { System Scale (i.e., } \\
\text { full, pilot, bench, } \\
\text { etc.) }\end{array}$ & Location & $\begin{array}{l}\text { ARG/ARB or } \\
\text { bacterial } \\
\text { indicator }\end{array}$ & $\begin{array}{c}\text { Concentration } \\
\operatorname{In}^{\mathrm{a}}\end{array}$ & $\begin{array}{c}\text { Concentration } \\
\text { Out }^{\mathrm{a}}\end{array}$ & $\begin{array}{c}\text { Log } \\
\text { Removal }\end{array}$ & Reference \\
\hline \multirow{4}{*}{ Full WWTP } & $\begin{array}{c}\text { Secondary } \\
\text { mechanical-biological } \\
\text { treatment plant } \\
\text { serving } \sim 120,000 \\
\text { population. No }\end{array}$ & \multirow{4}{*}{ Poland } & $\begin{array}{l}\text { Tetracycline } \\
\text { resistant } \\
\text { (February) }\end{array}$ & $1.90 \mathrm{E}+04^{\mathrm{ce}}$ & $2.30 \mathrm{E}+02$ & 1.917 & \multirow{4}{*}{$\begin{array}{c}\text { Makowska } \\
\text { et al., } \\
2016\end{array}$} \\
\hline & $\begin{array}{c}\text { WWTP collects about } \\
55,000 \mathrm{~m}^{3} \text { of } \\
\text { wastewater from } \\
\text { households }(70 \%),\end{array}$ & & $\begin{array}{l}\text { sulfamethoxazole } \\
\text { resistant } \\
\text { (February) }\end{array}$ & $1.70 \mathrm{E}+05^{\mathrm{ce}}$ & $2.90 \mathrm{E}+03$ & 1.768 & \\
\hline & $\begin{array}{l}\text { other sources. } \\
\text { (Samples collected } \\
\text { four times, } \\
\text { seasonally, on }\end{array}$ & & $\begin{array}{l}\text { Tetracycline } \\
\text { resistant (July) }\end{array}$ & $3.10 \mathrm{E}+04^{\mathrm{ce}}$ & $3.30 \mathrm{E}+02$ & 1.973 & \\
\hline & $\begin{array}{c}\text { December 2013, and } \\
\text { February, May and } \\
\text { July 2014) }\end{array}$ & & $\begin{array}{l}\text { sulfamethoxazole } \\
\text { resistant (July) }\end{array}$ & $4.00 \mathrm{E}+04^{\mathrm{ce}}$ & $1.30 \mathrm{E}+03$ & 1.488 & \\
\hline
\end{tabular}

${ }^{\text {a }}$ Removals calculated directly from values reported in the reference, when available, or extracted from the published figures using WebPlotDigitizer or manually when this was not possible; ${ }^{\mathrm{b}} \mathrm{qPCR}$; ${ }^{\mathrm{c}}$ culture-based method; ${ }^{\mathrm{d}}$ gene copies/ $\mathrm{mL} ;{ }^{\mathrm{e}} \mathrm{cfu} / \mathrm{mL}$

3.1.3.4 Advanced treatment

Table 12. Miscellaneous filters

\begin{tabular}{|c|c|c|c|c|c|c|c|}
\hline WWT Process & $\begin{array}{l}\text { System Scale (i.e., } \\
\text { full, pilot, bench, } \\
\text { etc.) }\end{array}$ & Location & $\begin{array}{c}\text { ARG/ARB or } \\
\text { bacterial } \\
\text { indicator }\end{array}$ & $\begin{array}{l}\text { Concentration } \\
\operatorname{In}^{\mathrm{a}}\end{array}$ & $\underset{\text { Out }^{\mathrm{a}}}{\text { Concentration }_{\mathrm{I}}}$ & $\begin{array}{c}\text { Log } \\
\text { Removal }\end{array}$ & Reference \\
\hline \multirow{5}{*}{$\begin{array}{l}\text { Membrane } \\
\text { bioreactor }\end{array}$} & $\begin{array}{c}\text { Full scale WWTP } \\
\text { receiving domestic } \\
\text { wastewater (44\%)and }\end{array}$ & & intl1 & $1.20 \mathrm{E}+06 \mathrm{~b}, \mathrm{~d}$ & $1.90 \mathrm{E}+04$ & 1.800 & \multirow{5}{*}{$\begin{array}{l}2015 \\
\text { Du et al., }\end{array}$} \\
\hline & $\begin{array}{c}\text { pre-treated industrial } \\
\text { wastewater (56\%) } \\
\text { (Composite samples }\end{array}$ & $\begin{array}{l}\text { Wuxi, } \\
\text { Jiangsu }\end{array}$ & sul1 & $3.50 \mathrm{E}+06^{\mathrm{b}, \mathrm{d}}$ & $5.50 \mathrm{E}+04$ & 1.804 & \\
\hline & $\begin{array}{c}\text { collected October } 2012 \\
\text { to September 2013, } \\
\text { (except for February 2013) }\end{array}$ & $\begin{array}{l}\text { Province, } \\
\text { China }\end{array}$ & tet $\mathrm{G}$ & $1.70 \mathrm{E}+05^{\mathrm{b}, \mathrm{d}}$ & $3.40 \mathrm{E}+03$ & 1.699 & \\
\hline & $\begin{array}{l}\text { median concentrations } \\
\text { estimated from figure } 3 \text {. } \\
16 \mathrm{~S} \text { values given for }\end{array}$ & & tetw & $2.20 \mathrm{E}+04^{\mathrm{b}, \mathrm{d}}$ & $2.00 \mathrm{E}+02$ & 2.041 & \\
\hline & sludge samples only). & & tet $\mathrm{X}$ & $1.70 \mathrm{E}+06^{\mathrm{b}, \mathrm{d}}$ & $6.50 \mathrm{E}+03$ & 2.418 & \\
\hline Peat Biofilter & $\begin{array}{c}\text { Household onsite } \\
\text { treatment and reuse } \\
\text { system serving a } 3 \\
\text { bedroom family farm; } \\
\text { expected daily volume } \\
1360 \text { L (Samples } \\
\text { collected August } 2013 \\
\text { to April 2014) }\end{array}$ & $\begin{array}{l}\text { Ohio } \\
\text { London, }\end{array}$ & tetQ & $1.90 \mathrm{E}+05^{\mathrm{b}, \mathrm{d}}$ & $1.10 \mathrm{E}+03$ & 2.237 & $\begin{array}{l}\text { Park et al., } \\
2016\end{array}$ \\
\hline \multirow{8}{*}{$\begin{array}{l}\text { Chemical } \\
\text { treatment } \\
\text { (aluminum } \\
\text { polychloride } \\
\text { enriched by } \\
\text { calcium } \\
\text { hydroxide and } \\
\text { anionic } \\
\text { polyacrylamide) }\end{array}$} & $\begin{array}{c}\text { Full scale, large } \\
\text { municipal WWTP }\end{array}$ & \multirow{8}{*}{$\begin{array}{l}\text { Verbania, } \\
\text { Italy }\end{array}$} & $\begin{array}{c}\text { arsB } \\
\text { blaCTX-M }\end{array}$ & $\begin{array}{l}1.86 \mathrm{E}+04^{\mathrm{b}, \mathrm{d}} \\
<\mathrm{LOQ}^{\mathrm{b}, \mathrm{d}}\end{array}$ & $\begin{array}{c}1.90 \mathrm{E}+04 \\
<\mathrm{LOQ}\end{array}$ & $\begin{array}{c}-0.009 \\
-\end{array}$ & \multirow{8}{*}{$\begin{array}{l}\text { Di Cesare } \\
\text { et al., } \\
2015\end{array}$} \\
\hline & $\begin{array}{c}\text { receiving domestic } \\
\text { sewage and pretreated }\end{array}$ & & blaTEM & $<\mathrm{LOQ}^{\mathrm{b}, \mathrm{d}}$ & $<\mathrm{LOQ}$ & - & \\
\hline & hospital sewage (Grab & & $c z c \mathrm{~A}$ & $9.04 \mathrm{E}+02^{\mathrm{b}, \mathrm{d}}$ & $6.81 \mathrm{E}+02$ & 0.123 & \\
\hline & $\begin{array}{l}\text { samples collected July } \\
\text { 2nd, 2015. Mean and }\end{array}$ & & ermB & $3.14 \mathrm{E}+03^{\mathrm{b}, \mathrm{d}}$ & $4.34 \mathrm{E}+02$ & 0.859 & \\
\hline & standard deviation & & intI1 & $3.42 \mathrm{E}+03^{\mathrm{b}, \mathrm{d}}$ & $2.70 \mathrm{E}+03$ & 0.103 & \\
\hline & $\begin{array}{c}\text { values of absolute } \\
\text { abundance from Table }\end{array}$ & & $q n r S$ & $9.59 \mathrm{E}+03^{\mathrm{b}, \mathrm{d}}$ & $1.18 \mathrm{E}+03$ & 0.910 & \\
\hline & $\mathrm{S} 2 . \mathrm{ND}=$ not & & sul2 & $5.44 \mathrm{E}+03^{\mathrm{b}, \mathrm{d}}$ & $3.11 \mathrm{E}+03$ & 0.243 & \\
\hline & detected. & & tetA & $1.16 \mathrm{E}+03^{\mathrm{b}, \mathrm{d}}$ & $1.30 \mathrm{E}+03$ & -0.049 & \\
\hline
\end{tabular}




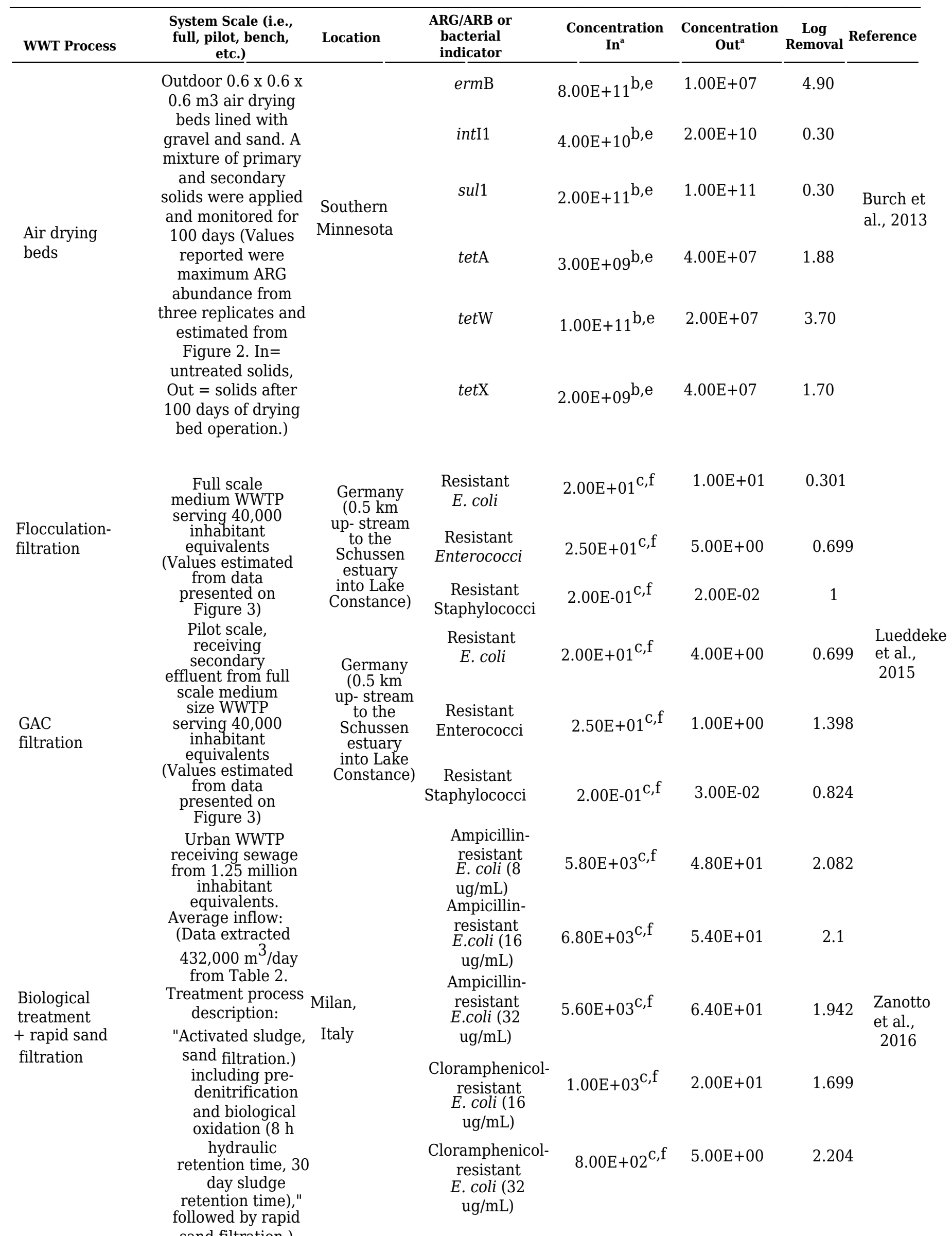




\subsubsection{Alkailine- anaerobic treatment systems}

High $\mathrm{pH}$ treatment is often used to sanitize biosolids, which is also effective in reducing ARGs (Munir et al., 2011). Taking this knowledge has also led to the application of anaerobic fermentation at pH 10 (Huang et al., 2016). Not only were ARGs reduced (compared to a neutral $\mathrm{pH}$ control) by some 0.4 to $1.4 \log _{10}$ units, but the high $\mathrm{pH}$ also reduced the microbial community structures of potential ARG hosts and ARG-associated naked DNA and bacteriophages (Huang et al., 2016). In a broad comparison of the effects of various wastewater biosolids stabilization technologies (air drying, aerobic digestion, mesophilic anaerobic digestion, thermophilic anaerobic digestion, pasteurization, and alkaline stabilization) alkaline stabilization was amongst the most effective for accelerating decay of intI1, tet(X), tet(A), tet(W), sul1, erm(B), and qnrA following soil amendment (Burch et al., 2017). So, providing another example of how changing the microbiome may also assist in reducing AMR risk, which could easily be applied by, for example, a lime-treatment stage for excreta-related solids prior to use.

\subsubsection{Sludge/manure management on soils}

Sanitation residuals applied to land, even following appropriate sludge/manure treatment to reduce AMR issues (see 3.2.1), could result in re-amplification of ARGs. Therefore, it is of interest to understand how to manage soil amendments containing sludge/manure to encourage further biodegradation. For example, when biosolids were added to sandy and silty-loam soils, from a group of five ARGs and intergrase of class 1 integron (intI1), the half-life decay rates were considerable slower than reported for wastewater treatment unit operations such as anaerobic digestion; ranging from 13 days (for erm(B), with $100 \mathrm{~g}$ of biosolids/manure per $\mathrm{kg}$ soil) to 81 days (intI1 at $40 \mathrm{~g} . \mathrm{kg}^{-1}$ ) (Burch et al., 2014; Fahrenfeld et al., 2014; Sharma et al., 2016). 
Table 13. Biosolids treatment Lab storage experiments from dewatered Class B Mesophilic digested sludge.

\begin{tabular}{|c|c|c|c|c|c|}
\hline Location & $\begin{array}{c}\text { ARG/ARB or bacterial } \\
\text { indicator }\end{array}$ & $\begin{array}{c}\text { Concentration } \\
\text { In }^{\mathrm{a}}\end{array}$ & Concentration Out ${ }^{\mathrm{a}}$ & Log Removal & Reference \\
\hline $\begin{array}{l}\text { Christiansburg, } \\
\text { VA; Storage at } \\
4{ }^{\circ} \mathrm{C} ; 1 \text { month } \\
\text { storage }\end{array}$ & intI1 & $3.00 \mathrm{E}+08^{\mathrm{b}, \mathrm{c}}$ & $8.00 E+08$ & -0.43 & \\
\hline $\begin{array}{l}\text { Christiansburg, } \\
\text { VA; Storage at } \\
4{ }^{\circ} \mathrm{C} ; 2 \text { month } \\
\text { storage }\end{array}$ & intI1 & $3.00 \mathrm{E}+08^{\mathrm{b}, \mathrm{c}}$ & $7.00 \mathrm{E}+08$ & -0.37 & $\begin{array}{l}\text { Miller et } \\
\text { al., } 2014\end{array}$ \\
\hline $\begin{array}{l}\text { Christiansburg, } \\
\text { VA; Storage at } \\
4{ }^{\circ} \mathrm{C} ; 4 \text { month } \\
\text { storage }\end{array}$ & intI1 & $3.00 \mathrm{E}+08^{\mathrm{b}, \mathrm{c}}$ & $4.00 \mathrm{E}+08$ & -0.12 & \\
\hline $\begin{array}{l}\text { Christiansburg, } \\
\text { VA; Storage at } \\
10^{\circ} \mathrm{C} ; 1 \text { month } \\
\text { storage }\end{array}$ & intI1 & $3.00 \mathrm{E}+08^{\mathrm{b}, \mathrm{c}}$ & $1.00 \mathrm{E}+09$ & -0.52 & \\
\hline $\begin{array}{l}\text { Christiansburg, } \\
\text { VA; Storage at } \\
10^{\circ} \mathrm{C} ; 2 \text { month } \\
\text { storage }\end{array}$ & intI1 & $3.00 \mathrm{E}+08^{\mathrm{b}, \mathrm{c}}$ & $7.00 \mathrm{E}+08$ & -0.37 & $\begin{array}{l}\text { Miller et } \\
\text { al., } 2014\end{array}$ \\
\hline $\begin{array}{l}\text { Christiansburg, } \\
\text { VA; Storage at } \\
10{ }^{\circ} \mathrm{C} ; 4 \text { month } \\
\text { storage }\end{array}$ & intI1 & $3.00 \mathrm{E}+08^{\mathrm{b}, \mathrm{c}}$ & $1.00 \mathrm{E}+09$ & -0.52 & \\
\hline $\begin{array}{l}\text { Christiansburg, } \\
\text { VA; Storage at } \\
20^{\circ} \mathrm{C} ; 1 \text { month } \\
\text { storage }\end{array}$ & intI1 & $3.00 \mathrm{E}+08^{\mathrm{b}, \mathrm{c}}$ & $5.00 \mathrm{E}+08$ & -0.22 & \\
\hline $\begin{array}{l}\text { Christiansburg, } \\
\text { VA; Storage at } \\
20^{\circ} \mathrm{C} ; 2 \text { month } \\
\text { storage }\end{array}$ & intI1 & $3.00 \mathrm{E}+08^{\mathrm{b}, \mathrm{c}}$ & $4.00 \mathrm{E}+08$ & -0.12 & $\begin{array}{l}\text { Miller et } \\
\text { al., } 2014\end{array}$ \\
\hline $\begin{array}{l}\text { Christiansburg, } \\
\text { VA; Storage at } \\
20{ }^{\circ} \mathrm{C} ; 4 \text { month } \\
\text { storage }\end{array}$ & intI1 & $3.00 \mathrm{E}+08^{\mathrm{b}, \mathrm{c}}$ & $5.00 \mathrm{E}+08$ & -0.22 & \\
\hline
\end{tabular}




\begin{tabular}{|c|c|c|c|c|c|}
\hline Location & $\begin{array}{c}\text { ARG/ARB or bacterial } \\
\text { indicator }\end{array}$ & $\begin{array}{c}\text { Concentration } \\
\text { In }^{\mathrm{a}} \\
\end{array}$ & Concentration Out ${ }^{\mathrm{a}}$ & Log Removal & Reference \\
\hline $\begin{array}{l}\text { Christiansburg, } \\
\text { VA; Storage at } \\
4{ }^{\circ} \mathrm{C} \text {; } 1 \text { month } \\
\text { storage }\end{array}$ & sul1 & $2.00 \mathrm{E}+10^{\mathrm{b}, \mathrm{c}}$ & $1.00 \mathrm{E}+12$ & -1.70 & \\
\hline $\begin{array}{l}\text { Christiansburg, } \\
\text { VA; Storage at } \\
4{ }^{\circ} \mathrm{C} ; 2 \text { month } \\
\text { storage }\end{array}$ & sul1 & $2.00 \mathrm{E}+10^{\mathrm{b}, \mathrm{c}}$ & $4.00 \mathrm{E}+12$ & -2.30 & $\begin{array}{l}\text { Miller et } \\
\text { al., } 2014\end{array}$ \\
\hline $\begin{array}{l}\text { Christiansburg, } \\
\text { VA; Storage at } \\
4{ }^{\circ} \mathrm{C} ; 4 \text { month } \\
\text { storage }\end{array}$ & sul1 & $2.00 \mathrm{E}+10^{\mathrm{b}, \mathrm{c}}$ & $1.00 \mathrm{E}+10$ & 0.30 & \\
\hline $\begin{array}{l}\text { Christiansburg, } \\
\text { VA; Storage at } \\
10^{\circ} \mathrm{C} ; 1 \text { month } \\
\text { storage }\end{array}$ & sul1 & $2.00 \mathrm{E}+10^{\mathrm{b}, \mathrm{c}}$ & $2.00 \mathrm{E}+10$ & 0.00 & \\
\hline $\begin{array}{l}\text { Christiansburg, } \\
\text { VA; Storage at } \\
10^{\circ} \mathrm{C} ; 2 \text { month } \\
\text { storage }\end{array}$ & sul1 & $2.00 \mathrm{E}+10^{\mathrm{b}, \mathrm{c}}$ & $4.00 \mathrm{E}+10$ & -0.30 & $\begin{array}{l}\text { Miller et } \\
\text { al., } 2014\end{array}$ \\
\hline $\begin{array}{l}\text { Christiansburg, } \\
\text { VA; Storage at } \\
10^{\circ} \mathrm{C} ; 4 \text { month } \\
\text { storage }\end{array}$ & sul1 & $2.00 \mathrm{E}+10^{\mathrm{b}, \mathrm{c}}$ & $2.00 \mathrm{E}+10$ & 0.00 & \\
\hline $\begin{array}{l}\text { Christiansburg, } \\
\text { VA; Storage at } \\
20^{\circ} \mathrm{C} ; 1 \text { month } \\
\text { storage }\end{array}$ & sul1 & $2.00 \mathrm{E}+10^{\mathrm{b}, \mathrm{c}}$ & $7.00 \mathrm{E}+10$ & -0.54 & \\
\hline $\begin{array}{l}\text { Christiansburg, } \\
\text { VA; Storage at } \\
20^{\circ} \mathrm{C} ; 2 \text { month } \\
\text { storage }\end{array}$ & sul1 & $2.00 \mathrm{E}+10^{\mathrm{b}, \mathrm{c}}$ & $3.00 \mathrm{E}+10$ & -0.18 & $\begin{array}{l}\text { Miller et } \\
\text { al., } 2014\end{array}$ \\
\hline $\begin{array}{l}\text { Christiansburg, } \\
\text { VA; Storage at } \\
20^{\circ} \mathrm{C} ; 4 \text { month }\end{array}$ & sul1 & $2.00 \mathrm{E}+10^{\mathrm{b}, \mathrm{c}}$ & $1.00 \mathrm{E}+10$ & 0.30 & \\
\hline
\end{tabular}

Data estimated from Figure 1 ; Removals calculated directly from values reported in the reference, when available, or extracted from the published figures using WebPlotDigitizer or manually when this was not possible; ${ }^{b} \mathrm{qPCR}$; ${ }^{\mathrm{c} g e n e}$ copies/ $\mathrm{g}$ total solid

\subsection{Disinfection}

\subsubsection{UV, ozone or chlorination disinfection of effluents}

Processes that stress, but do not kill, targeted bacteria provide a mechanism to select for stress-resistant biotypes, including those with enhanced uptake of ARGs. For example, using an E. coli model, Guo et al. (2015) demonstrated that moderate to high doses of UV ( $>10$ $\mathrm{mJ} . \mathrm{cm}^{-2}$ ) or chlorine (>80 mg Cl min. $\mathrm{L}^{-1}$ ) greatly suppressed ARG transfer, but lower levels of chlorination (up to $40 \mathrm{mg}$ min. $\mathrm{L}^{-1}$ ) led to a $2-5$ fold increase in conjugative ARG transfer. Similar increased risk of ARG transfer by chlorination has also been reported by others (Rizzo et al., 2013a). The other common oxidant, ozone, also appears less effective, providing 4-log pB10 plasmid removal efficiency at $127.15 \mathrm{mg} . \mathrm{min} \mathrm{L}^{-1}$, which was 1.04 - and 1.25fold higher than those required for ARB (122.73 mg.min $\mathrm{L}^{-1}$ ) and a model non-antibiotic resistant bacterial strain, E. coli K-12, (101.4 mg.min L ${ }^{-1}$ ), respectively (Pak et al., 2016).

However, when using molecular-methods to collectively assay an array of genes comprising the "resistome," UV treatment has been reported to only reduce tetX and $16 \mathrm{~S}$ rRNA genes by 0.58 and $0.60 \log _{10}$ units, respectively, with other genes reduced 0.36-0.40 even when the dose was increased to $250 \mathrm{~mJ} . \mathrm{cm}^{-2}$ (Zhang et al., 2015b). Hence, Zhang et al. (2015) recommended a sequential UV/chlorination treatment, to enhance ARG removal, which has also been shown to be effective with 0.05-2.0 mg. $\mathrm{L}^{-1}$ chlorination (Lin et al., 2016a).

Another biocide used in sanitation is ammonia nitrogen 
$\left(\mathrm{NH}_{3}-\mathrm{N}\right)$ (Fidjeland et al., 2015), which can also be used in combination with chlorination to enhance ARG removal (1.2-1.5 $\log _{10}$ reduction at a $\mathrm{Cl}_{2}: \mathrm{NH}_{3}-\mathrm{N}$ ratio over 7.6:1) (Zhang et al., 2015b).

Hence, with due consideration of modes of activity, both UV and chlorination can be effective in reducing ARGs and mobile genetic elements rather than co-selecting for them (Lin et al., 2016b). Overall, known benefits of such disinfection processes for pathogen reduction likely outweigh lesser established concerns regarding potential to enhance AMR.

An important consideration when using molecular methods to assess the effectiveness of disinfectants is that it is essential to employ as long a qPCR amplicon product as possible (e.g., 1,000 bp) in order to capture sufficient DNA damage and for the kinetics to be meaningful (McKinney and Pruden, 2012). Further, a re-growth step following disinfection and before molecular analysis can aid in determining what the net effect of disinfection will be downstream, in terms of selection of potentially more resistant strains.

Table 14. Disinfection

\begin{tabular}{|c|c|c|c|c|c|c|c|}
\hline WWT Process & $\begin{array}{c}\text { System Scale } \\
\text { (i.e., full, pilot, } \\
\text { bench, etc.) }\end{array}$ & Location & $\begin{array}{l}\text { ARG/ARB or } \\
\text { bacterial } \\
\text { indicator }\end{array}$ & $\begin{array}{c}\text { Concentration } \\
\text { In }^{\mathrm{a}}\end{array}$ & $\begin{array}{c}\text { Concentration } \\
\text { Out }^{\mathrm{a}}\end{array}$ & $\begin{array}{c}\text { Log } \\
\text { Removal }\end{array}$ & Reference \\
\hline $\begin{array}{l}\text { Chlorine } \\
\text { disinfection }\end{array}$ & $\begin{array}{l}\text { WWTP1 treating } \\
\text { approx. 540,000 } \\
\mathrm{m}^{3} / \text { day from a } \\
\text { population of } 2.1 \\
\text { million. Plant } \\
\text { employs anaerobic } \\
\text { and anoxic lagoons } \\
\text { followed by a } \\
\text { conventional } \\
\text { activated sludge } \\
\text { process with } \\
\text { chlorine } \\
\text { disinfection } \\
\text { (contact time of } 30 \\
\text { min at } 5 \text { mg/L } \\
\text { (One-liter } \\
\text { composite samples } \\
\text { collected every } 2 \mathrm{~h} \\
\text { for } 24 \text { h from outlet } \\
\text { of each treatment } \\
\text { unit using a GRASP } \\
\text { refrigerated } \\
\text { automatic sampler. } \\
\text { Data estimated } \\
\text { from Figure } 2 . \text {.) }\end{array}$ & $\begin{array}{l}\text { Northern } \\
\text { China }\end{array}$ & $\begin{array}{l}\text { sul (sul1, sul2, } \\
\text { and sul } 3 \text { ) } \\
\text { tet (tet } \mathrm{A}, \text { tet } \mathrm{B}, \\
\text { tet } \mathrm{C} \text {, tet } \mathrm{D}, \\
\text { tet } \mathrm{E}, \text { tet } \mathrm{G}, \\
\text { tet } \mathrm{H}, \text { tet } \mathrm{M}, \\
\text { tet } \mathrm{L}, \text { tet } \mathrm{O}, \\
\text { tet } \mathrm{Q}, \text { tet } \mathrm{X} \\
\text { tet } \mathrm{T}, \text { tet } \mathrm{W} \\
\text { and } \text { tet } \mathrm{S})\end{array}$ & $8.63 \mathrm{E}+07^{\mathrm{b}, \mathrm{d}}$ & $9.73 E+02$ & 0.327 & $\begin{array}{c}\text { Mao et al., } \\
2015\end{array}$ \\
\hline
\end{tabular}




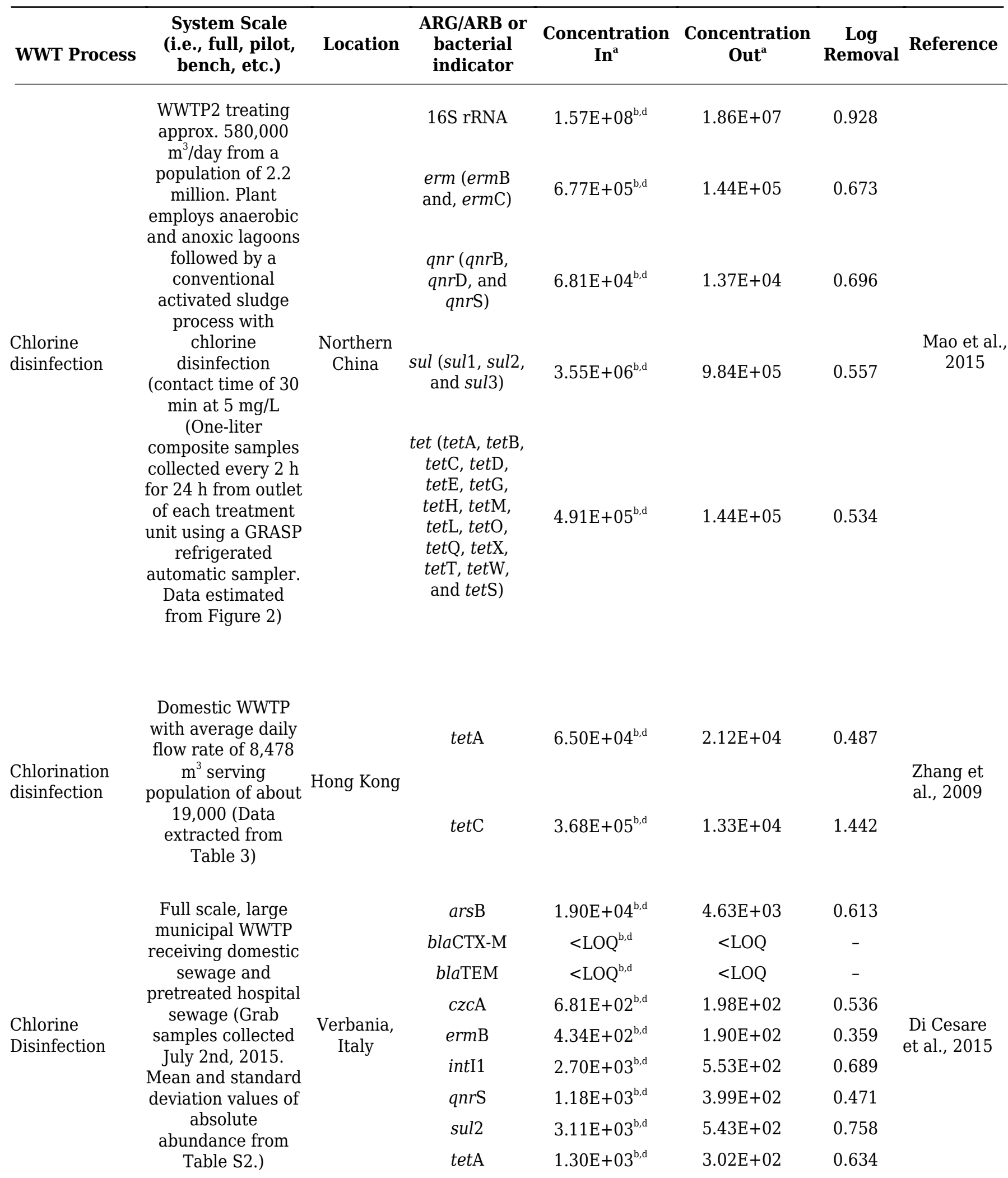




\begin{tabular}{|c|c|c|c|c|c|c|c|}
\hline WWT Process & $\begin{array}{l}\text { System Scale } \\
\text { (i.e., full, pilot, } \\
\text { bench, etc.) }\end{array}$ & Location & $\begin{array}{l}\text { ARG/ARB or } \\
\text { bacterial } \\
\text { indicator }\end{array}$ & $\begin{array}{c}\text { Concentration } \\
\text { In }^{\mathrm{a}}\end{array}$ & $\begin{array}{c}\text { Concentration } \\
\text { Out }^{\mathrm{a}}\end{array}$ & $\begin{array}{c}\text { Log } \\
\text { Removal }\end{array}$ & Reference \\
\hline \multirow{9}{*}{$\begin{array}{l}\text { Peracetic acid } \\
\text { disinfection }\end{array}$} & \multirow{9}{*}{$\begin{array}{c}\text { Full scale, small } \\
\text { municipal WWTP } \\
\text { receiving domestic } \\
\text { sewage (Grab } \\
\text { samples collected } \\
\text { July 13th, 2015. } \\
\text { Mean and standard } \\
\text { deviation values of } \\
\text { absolute } \\
\text { abundance from } \\
\text { Table S2.) }\end{array}$} & \multirow{9}{*}{$\begin{array}{l}\text { Cannobio, } \\
\text { Italy }\end{array}$} & $\operatorname{arsB}$ & $3.82 \mathrm{E}+04^{\mathrm{b}, \mathrm{d}}$ & $2.63 \mathrm{E}+04$ & 0.162 & \multirow{9}{*}{$\begin{array}{c}\text { Di Cesare } \\
\text { et al., } 2015\end{array}$} \\
\hline & & & blaCTX-M & $\mathrm{N} / \mathrm{A}^{\mathrm{b}, \mathrm{d}}$ & N/A & - & \\
\hline & & & blaTEM & $N / A^{b, d}$ & $<\mathrm{LOQ}$ & - & \\
\hline & & & $c z c \mathrm{~A}$ & $7.25 \mathrm{E}+02^{\mathrm{b}, \mathrm{d}}$ & $5.29 \mathrm{E}+02$ & 0.137 & \\
\hline & & & ermB & $1.21 \mathrm{E}+03^{\mathrm{b}, \mathrm{d}}$ & $1.84 \mathrm{E}+03$ & -0.182 & \\
\hline & & & intI1 & $6.43 \mathrm{E}+03^{\mathrm{b}, \mathrm{d}}$ & $7.78 \mathrm{E}+03$ & -0.083 & \\
\hline & & & qnrS & $5.10 \mathrm{E}+02^{\mathrm{b}, \mathrm{d}}$ & $1.44 \mathrm{E}+03$ & -0.451 & \\
\hline & & & sul2 & $2.49 \mathrm{E}+03^{\mathrm{b}, \mathrm{d}}$ & $2.96 \mathrm{E}+03$ & -0.075 & \\
\hline & & & tetA & $7.06 \mathrm{E}+02^{\mathrm{b}, \mathrm{d}}$ & $5.33 \mathrm{E}+02$ & 0.122 & \\
\hline \multirow{4}{*}{$\begin{array}{l}\mathrm{NaClO} \\
\text { disinfection + } \\
\text { Rapid gravity } \\
\text { sand filtration } \\
\text { + dichlorination }\end{array}$} & $\begin{array}{c}\text { Full scale activated } \\
\text { sludge WWTP }\end{array}$ & \multirow{4}{*}{$\begin{array}{l}\text { East } \\
\text { Lansing, } \\
\text { MI, USA }\end{array}$} & 16S rRNA & $2.00 \mathrm{E}+08^{\mathrm{b}, \mathrm{d}}$ & $6.31 \mathrm{E}+07$ & 0.500 & \multirow{4}{*}{$\begin{array}{l}\text { Gao et al., } \\
2012\end{array}$} \\
\hline & $\begin{array}{l}\text { (Grab samples } \\
\text { collected during } \\
\text { four sampling }\end{array}$ & & sulI & $1.58 \mathrm{E}+04^{\mathrm{b}, \mathrm{d}}$ & $1.00 \mathrm{E}+04$ & 0.200 & \\
\hline & $\begin{array}{l}\text { events between } \\
\text { July and December } \\
\text { 2010. Mean values }\end{array}$ & & tetO & $3.16 \mathrm{E}+04^{\mathrm{b}, \mathrm{d}}$ & $7.94 \mathrm{E}+03$ & 0.600 & \\
\hline & $\begin{array}{l}\text { estimated from } \\
\text { Figure 4.) }\end{array}$ & & tetW & $1.58 \mathrm{E}+04^{\mathrm{b}, \mathrm{d}}$ & $5.01 \mathrm{E}+03$ & 0.500 & \\
\hline $\begin{array}{l}\text { Complete } \\
\text { mixing batch } \\
\text { chlorinatino }\end{array}$ & $\begin{array}{l}\text { Household onsite } \\
\text { treatment and } \\
\text { reuse system } \\
\text { serving a } 3 \\
\text { bedroom family } \\
\text { farm; expected } \\
\text { daily volume 1,360 } \\
\text { L (Samples } \\
\text { collected August } \\
2013 \text { to April 2014) }\end{array}$ & $\begin{array}{l}\text { London, } \\
\text { Ohio, USA }\end{array}$ & tetQ & $1.10 \mathrm{E}+03^{\mathrm{b}, \mathrm{d}}$ & $9.90 \mathrm{E}+03$ & -0.954 & $\begin{array}{c}\text { Park et al., } \\
2016\end{array}$ \\
\hline \multirow{4}{*}{ Chlorination } & \multirow{4}{*}{$\begin{array}{l}\text { Full WWTP (ARG } \\
\text { abundance means } \\
\text { estimated from } \\
\text { Figure } 4 \text { a and b) }\end{array}$} & \multirow{4}{*}{$\begin{array}{l}\text { Jeddah, } \\
\text { Saudi } \\
\text { Arabia }\end{array}$} & tetO & $2.00 \mathrm{E}+02^{\mathrm{b}, \mathrm{d}}$ & $2.50 \mathrm{E}+02$ & -0.097 & \multirow{4}{*}{$\begin{array}{l}\text { Al-Jassim } \\
\text { et al., } 2015\end{array}$} \\
\hline & & & tetQ & $8.80 \mathrm{E}+02^{\mathrm{b}, \mathrm{d}}$ & $1.80 \mathrm{E}+02$ & 0.689 & \\
\hline & & & tetW & $1.10 \mathrm{E}+03^{\mathrm{b}, \mathrm{d}}$ & $4.50 \mathrm{E}+02$ & 0.388 & \\
\hline & & & tetZ & $4.90 \mathrm{E}+03^{\mathrm{b}, \mathrm{d}}$ & $5.40 \mathrm{E}+03$ & -0.042 & \\
\hline \multirow{5}{*}{ Ozonation } & $\begin{array}{l}\text { Pilot scale, } \\
\text { receiving effluent } \\
\text { from full scale } \\
\text { WWTP (ARG }\end{array}$ & & ampC & $7.80 \mathrm{E}+01^{\mathrm{b}, \mathrm{d}}$ & $2.30 \mathrm{E}+01$ & 0.530 & \multirow{5}{*}{$\begin{array}{l}\text { Alexander } \\
\text { et al., } 2016\end{array}$} \\
\hline & abundance values & & blaVIM & $8.70 \mathrm{E}+01^{\mathrm{b}, \mathrm{d}}$ & $7.10 \mathrm{E}+01$ & 0.088 & \\
\hline & $\begin{array}{c}\text { were extracted } \\
\text { from Table } 3 \text { and }\end{array}$ & Germany & & & & & \\
\hline & $\begin{array}{l}\text { represent the } \\
\text { medians calculated } \\
\text { from } 4824-\mathrm{h}\end{array}$ & & ermB & $1.40 \mathrm{E}+02^{\mathrm{b}, \mathrm{d}}$ & $1.10 \mathrm{E}+00$ & 2.105 & \\
\hline & $\begin{array}{c}\text { composite samples } \\
\text { over } 2 \text { vears.) }\end{array}$ & & vanA & $8.70 \mathrm{E}+02^{\mathrm{b}, \mathrm{d}}$ & $4.30 \mathrm{E}+02$ & 0.306 & \\
\hline
\end{tabular}




\begin{tabular}{|c|c|c|c|c|c|c|c|}
\hline WWT Process & $\begin{array}{l}\text { System Scale } \\
\text { (i.e., full, pilot, } \\
\text { bench, etc.) }\end{array}$ & Location & $\begin{array}{l}\text { ARG/ARB or } \\
\text { bacterial } \\
\text { indicator }\end{array}$ & $\begin{array}{l}\text { Concentration } \\
\text { In }^{\mathrm{a}}\end{array}$ & $\begin{array}{c}\text { Concentration } \\
\text { Out }^{\mathrm{a}}\end{array}$ & $\begin{array}{c}\text { Log } \\
\text { Removal }\end{array}$ & Reference \\
\hline \multirow{3}{*}{ Ozonation } & $\begin{array}{c}\text { Pilot scale, } \\
\text { receiving } \\
\text { secondary effluent }\end{array}$ & & $\begin{array}{c}\text { Resistant } E . \\
\text { coli }\end{array}$ & $2.00 \mathrm{E}+01^{\mathrm{c}, \mathrm{e}}$ & $1.00 \mathrm{E}+00$ & 1.301 & \multirow{3}{*}{$\begin{array}{l}\text { Lueddeke } \\
\text { et al., } 2015\end{array}$} \\
\hline & $\begin{array}{c}\text { from full scale } \\
\text { medium size WWTP } \\
\text { serving } 40,000 \\
\text { inhabitant }\end{array}$ & $\begin{array}{l}\text { stream to } \\
\text { the } \\
\text { Schussen }\end{array}$ & $\begin{array}{l}\text { Resistant } \\
\text { Enterococci }\end{array}$ & $2.50 \mathrm{E}+01^{\mathrm{c}, \mathrm{e}}$ & $1.00 \mathrm{E}-01$ & 2.398 & \\
\hline & $\begin{array}{c}\text { equivalents (Values } \\
\text { estimated from } \\
\text { data presented on } \\
\text { Figure 3) }\end{array}$ & $\begin{array}{c}\text { estuary } \\
\text { into Lake } \\
\text { Constance) }\end{array}$ & $\begin{array}{c}\text { Resistant } \\
\text { Staphylococci }\end{array}$ & $2.00 \mathrm{E}-01^{\mathrm{c}, \mathrm{e}}$ & $1.50 \mathrm{E}-02$ & 1.125 & \\
\hline \multirow{12}{*}{$\begin{array}{l}\text { UV disinfection } \\
\text { and } \\
\text { constructed } \\
\text { wetland system }\end{array}$} & & \multirow{12}{*}{$\begin{array}{l}\text { Linan City, } \\
\text { China }\end{array}$} & intI1 & $2.88 \mathrm{E}+09^{\mathrm{b}, \mathrm{d}}$ & $3.84 \mathrm{E}+09$ & -0.125 & \multirow{12}{*}{$\begin{array}{l}\text { Li et al., } \\
2015\end{array}$} \\
\hline & Full WWTP & & sul1 & $4.30 \mathrm{E}+09^{\mathrm{b}, \mathrm{d}}$ & $2.22 \mathrm{E}+09$ & 0.287 & \\
\hline & receiving domestic & & sul2 & $7.66 \mathrm{E}+08^{\mathrm{b}, \mathrm{d}}$ & $6.93 E+08$ & 0.043 & \\
\hline & sewage from urban & & tetA & $8.50 \mathrm{E}+07^{\mathrm{b}, \mathrm{d}}$ & $5.60 \mathrm{E}+07$ & 0.181 & \\
\hline & areas, serving & & tetB & $4.93 \mathrm{E}+06^{\mathrm{b}, \mathrm{d}}$ & $3.30 \mathrm{E}+06$ & 0.174 & \\
\hline & 300,000 people & & tetC & $1.79 \mathrm{E}+08^{\mathrm{b}, \mathrm{d}}$ & $1.77 \mathrm{E}+08$ & 0.005 & \\
\hline & (Composite & & tet $\mathrm{G}$ & $3.90 \mathrm{E}+08^{\mathrm{b}, \mathrm{d}}$ & $5.67 \mathrm{E}+08$ & -0.163 & \\
\hline & March to May, & & tetL & $1.49 \mathrm{E}+07^{\mathrm{b}, \mathrm{d}}$ & $3.81 \mathrm{E}+06$ & 0.592 & \\
\hline & 2013. Sample & & tet $\mathrm{M}$ & $6.39 \mathrm{E}+06^{\mathrm{b}, \mathrm{d}}$ & $5.06 \mathrm{E}+07$ & -0.899 & \\
\hline & $\begin{array}{l}\text { concentrations } \\
\text { estimated with }\end{array}$ & & tetO & $6.45 \mathrm{E}+08^{\mathrm{b}, \mathrm{d}}$ & $1.74 \mathrm{E}+08$ & 0.569 & \\
\hline & WebPlotDigitizer & & tetQ & $1.25 \mathrm{E}+09^{\mathrm{b}, \mathrm{d}}$ & $3.74 \mathrm{E}+07$ & 1.524 & \\
\hline & from figure S3) & & tetw & $3.43 \mathrm{E}+08^{\mathrm{b}, \mathrm{d}}$ & $1.67 \mathrm{E}+08$ & 0.313 & \\
\hline \multirow{15}{*}{ UV disinfection } & & \multirow{13}{*}{$\begin{array}{l}\text { Eastern } \\
\text { China }\end{array}$} & tetX & $1.67 \mathrm{E}+08^{\mathrm{b}, \mathrm{d}}$ & $5.12 \mathrm{E}+08$ & -0.487 & \multirow{27}{*}{$\begin{array}{l}\text { Li et al., } \\
2016\end{array}$} \\
\hline & & & intI1 & $8.00 \mathrm{E}+08^{\mathrm{b}, \mathrm{d}}$ & $6.00 \mathrm{E}+08$ & 0.125 & \\
\hline & & & sul1 & $1.30 \mathrm{E}+09^{\mathrm{b}, \mathrm{d}}$ & $1.90 \mathrm{E}+08$ & 0.835 & \\
\hline & & & sul2 & $5.50 \mathrm{E}+05^{\mathrm{b}, \mathrm{d}}$ & $2.00 \mathrm{E}+05$ & 0.439 & \\
\hline & $\begin{array}{l}\text { Full scale medium } \\
\text { sized WWTP }\end{array}$ & & tetA & $4.00 \mathrm{E}+08^{\mathrm{b}, \mathrm{d}}$ & $2.60 \mathrm{E}+08$ & 0.187 & \\
\hline & capacity $60,000 t$ & & tetB & $8.00 \mathrm{E}+06^{\mathrm{b}, \mathrm{d}}$ & $5.50 \mathrm{E}+06$ & 0.163 & \\
\hline & (Composite & & tetC & $3.00 \mathrm{E}+09^{\mathrm{b}, \mathrm{d}}$ & $2.30 \mathrm{E}+09$ & 0.115 & \\
\hline & $\begin{array}{l}\text { samples collected } \\
\text { September and }\end{array}$ & & tetG & $8.50 \mathrm{E}+08^{\mathrm{b}, \mathrm{d}}$ & $3.00 \mathrm{E}+08$ & 0.452 & \\
\hline & October, 2013; & & tetL & $9.00 \mathrm{E}+06^{\mathrm{b,d}}$ & $5.50 \mathrm{E}+06$ & 0.214 & \\
\hline & concentration & & tet $\mathrm{M}$ & $2.00 \mathrm{E}+07^{\mathrm{b}, \mathrm{d}}$ & $1.20 \mathrm{E}+07$ & 0.222 & \\
\hline & $\begin{array}{l}\text { values estimated } \\
\text { from Figure 3) }\end{array}$ & & tetO & $5.00 \mathrm{E}+07^{\mathrm{b}, \mathrm{d}}$ & $2.60 \mathrm{E}+07$ & 0.284 & \\
\hline & & & tetQ & $1.00 \mathrm{E}+08^{\mathrm{b}, \mathrm{d}}$ & $6.00 \mathrm{E}+07$ & 0.222 & \\
\hline & & & tetw & $8.00 \mathrm{E}+06^{\mathrm{b}, \mathrm{d}}$ & $6.50 \mathrm{E}+06$ & 0.090 & \\
\hline & & \multirow{14}{*}{$\begin{array}{l}\text { Eastern } \\
\text { China }\end{array}$} & tetX & $8.00 \mathrm{E}+08^{\mathrm{b}, \mathrm{d}}$ & $1.70 \mathrm{E}+08$ & 0.673 & \\
\hline & & & intI1 & $5.00 \mathrm{E}+08^{\mathrm{b}, \mathrm{d}}$ & $4.00 \mathrm{E}+08$ & 0.097 & \\
\hline \multirow{12}{*}{ UV disinfection } & & & sul1 & $7.00 \mathrm{E}+08^{\mathrm{b}, \mathrm{d}}$ & $3.70 \mathrm{E}+08$ & 0.277 & \\
\hline & Full scale WWTP & & sul2 & $1.60 \mathrm{E}+08^{\mathrm{b}, \mathrm{d}}$ & $1.00 \mathrm{E}+08$ & 0.204 & \\
\hline & receiving domestic & & tetA & $5.50 \mathrm{E}+07^{\mathrm{b}, \mathrm{d}}$ & $4.00 \mathrm{E}+07$ & 0.138 & \\
\hline & industrial effluents, & & tetB & $2.10 \mathrm{E}+06^{\mathrm{b}, \mathrm{d}}$ & $1.60 \mathrm{E}+06$ & 0.118 & \\
\hline & capacity: $400,000 t$ & & tetC & $1.70 \mathrm{E}+08^{\mathrm{b}, \mathrm{d}}$ & $8.50 \mathrm{E}+07$ & 0.301 & \\
\hline & $\begin{array}{c}\text { (Composite } \\
\text { samples collected }\end{array}$ & & tet $\mathrm{G}$ & $3.70 \mathrm{E}+08^{\mathrm{b}, \mathrm{d}}$ & $1.80 \mathrm{E}+08$ & 0.313 & \\
\hline & September and & & tetL & $1.90 \mathrm{E}+06^{\mathrm{b}, \mathrm{d}}$ & $1.70 \mathrm{E}+06$ & 0.048 & \\
\hline & October, 2013; & & tet $\mathrm{M}$ & $4.20 \mathrm{E}+06^{\mathrm{b}, \mathrm{d}}$ & $2.60 \mathrm{E}+06$ & 0.208 & \\
\hline & $\begin{array}{c}\text { concentration } \\
\text { values estimated }\end{array}$ & & tetO & $9.00 \mathrm{E}+06^{\mathrm{b}, \mathrm{d}}$ & $7.50 \mathrm{E}+06$ & 0.079 & \\
\hline & from Figure 3) & & tetQ & $2.60 \mathrm{E}+07^{\mathrm{b}, \mathrm{d}}$ & $1.80 \mathrm{E}+07$ & 0.160 & \\
\hline & & & tetW & $1.30 \mathrm{E}+08^{\mathrm{b}, \mathrm{d}}$ & $1.00 \mathrm{E}+08$ & 0.114 & \\
\hline & & & tetX & $2.60 \mathrm{E}+07^{\mathrm{b}, \mathrm{d}}$ & $1.20 \mathrm{E}+07$ & 0.336 & \\
\hline
\end{tabular}




\begin{tabular}{|c|c|c|c|c|c|c|c|}
\hline WWT Process & $\begin{array}{c}\text { System Scale } \\
\text { (i.e., full, pilot, } \\
\text { bench, etc.) }\end{array}$ & Location & $\begin{array}{l}\text { ARG/ARB or } \\
\text { bacterial } \\
\text { indicator }\end{array}$ & $\begin{array}{c}\text { Concentration } \\
\text { In }^{\mathrm{a}}\end{array}$ & $\begin{array}{c}\text { Concentration } \\
\text { Out }^{\mathrm{a}}\end{array}$ & $\begin{array}{c}\text { Log } \\
\text { Removal }\end{array}$ & Reference \\
\hline \multirow{8}{*}{ UV disinfection } & $\begin{array}{c}\text { Full scale WWTP } \\
\text { with average daily }\end{array}$ & \multirow{8}{*}{$\begin{array}{l}\text { Harbin, } \\
\text { China }\end{array}$} & 16S rRNA & $1.23 \mathrm{E}+07^{\mathrm{b}, \mathrm{d}}$ & $7.66 \mathrm{E}+06$ & 0.301 & \multirow{8}{*}{$\begin{array}{l}\text { Wen et al., } \\
2016\end{array}$} \\
\hline & flow of 150,000 & & blaCTX-M & $7.00 \mathrm{E}+02^{\mathrm{b}, \mathrm{d}}$ & $3.00 \mathrm{E}+02$ & 0.37 & \\
\hline & $\begin{array}{c}\mathrm{m}^{3} / \mathrm{d} \text {, using a cyclic } \\
\text { activated sludge }\end{array}$ & & intI1 & $2.00 \mathrm{E}+05^{\mathrm{b}, \mathrm{d}}$ & $1.00 \mathrm{E}+05$ & 0.30 & \\
\hline & $\begin{array}{l}\text { system. (WWTP } \\
\text { sampled once a }\end{array}$ & & sul1 & $1.00 \mathrm{E}+04^{\mathrm{b}, \mathrm{d}}$ & $6.00 \mathrm{E}+03$ & 0.22 & \\
\hline & $\begin{array}{c}\text { month from } \\
\text { November } 2013 \text { to }\end{array}$ & & sul2 & $3.00 \mathrm{E}+05^{\mathrm{b}, \mathrm{d}}$ & $2.00 \mathrm{E}+05$ & 0.18 & \\
\hline & $\begin{array}{l}\text { April 2014. Median } \\
\text { values estimated }\end{array}$ & & tetA & $4.00 \mathrm{E}+02^{\mathrm{b}, \mathrm{d}}$ & $1.00 \mathrm{E}+02$ & 0.60 & \\
\hline & from data & & tetO & $3.00 \mathrm{E}+02^{\mathrm{b}, \mathrm{d}}$ & $1.00 \mathrm{E}+02$ & 0.48 & \\
\hline & $\begin{array}{c}\text { presented in Figure } \\
\text { S3.) }\end{array}$ & & tetw & $1.00 \mathrm{E}+04^{\mathrm{b}, \mathrm{d}}$ & $7.00 \mathrm{E}+03$ & 0.15 & \\
\hline
\end{tabular}

${ }^{a}$ Removals calculated directly from values reported in the reference, when available, or extracted from the published figures using WebPlotDigitizer or manually when this was not possible; ${ }^{b}{ }^{\mathrm{CPCR}}$; ${ }^{\mathrm{c}}$ culture-dependent; ${ }^{\mathrm{d}}$ gene copy/ mL; ${ }^{\mathrm{e}} \mathrm{CFU} /$ $\mathrm{mL} ;-=$ not reported; $<\mathrm{LOQ}=$ below limit of quantification; N/A = negative

Table 15. Treatment with disinfection

\begin{tabular}{|c|c|c|c|c|c|}
\hline WWT Process & System Scale (i.e., full, pilot, bench, etc.) & Location & $\begin{array}{c}\text { ARG/ARB or } \\
\text { bacterial } \\
\text { indicator }\end{array}$ & $\begin{array}{c}\text { Log } \\
\text { Removal }^{\mathrm{a}}\end{array}$ & Reference \\
\hline \multirow{4}{*}{$\begin{array}{l}\text { Full WWTP } \\
\text { with } \\
\text { membrane } \\
\text { biological } \\
\text { reactor and } \\
\text { UV } \\
\text { disinfection }\end{array}$} & \multirow{4}{*}{$\begin{array}{l}\text { Full scale; Log removal by disinfection } \\
\text { (Samples (2-3) taken between Dec } 2008 \text { to Oct } \\
\text { 2009; DNA extracted with MagNA pure Compact } \\
\text { DNA extraction machine; concentrations not } \\
\text { reported for individual sampling sites; log removal } \\
\text { estimated from Figure 3) }\end{array}$} & & 16S rRNA & 3.60 & \multirow{8}{*}{$\begin{array}{l}\text { Munir et } \\
\text { al., } 2011\end{array}$} \\
\hline & & $\begin{array}{c}\text { Traverse } \\
\text { City }\end{array}$ & sul1 & 3.40 & \\
\hline & & $\begin{array}{l}\text { Michigan } \\
\text { USA }\end{array}$ & tetO & 8.00 & \\
\hline & & & tetw & 7.90 & \\
\hline \multirow{4}{*}{$\begin{array}{l}\text { Full WWTP } \\
\text { with } \\
\text { membrane } \\
\text { biological } \\
\text { reactor and } \\
\text { UV } \\
\text { disinfection }\end{array}$} & \multirow{4}{*}{$\begin{array}{l}\text { Full scale; Log removal by physical and biological } \\
\text { treatment } \\
\text { (Samples (2-3) taken between Dec } 2008 \text { to Oct } \\
\text { 2009; DNA extracted with MagNA pure Compact } \\
\text { DNA extraction machine; concentrations not } \\
\text { reported for individual sampling sites; log removal } \\
\text { estimated from Figure 3) }\end{array}$} & & 16S rRNA & 3.40 & \\
\hline & & $\begin{array}{c}\text { Traverse } \\
\text { City, }\end{array}$ & sul1 & 2.50 & \\
\hline & & $\begin{array}{l}\text { Michigan } \\
\text { USA }\end{array}$ & tetO & 7.00 & \\
\hline & & & tetw & 6.00 & \\
\hline
\end{tabular}




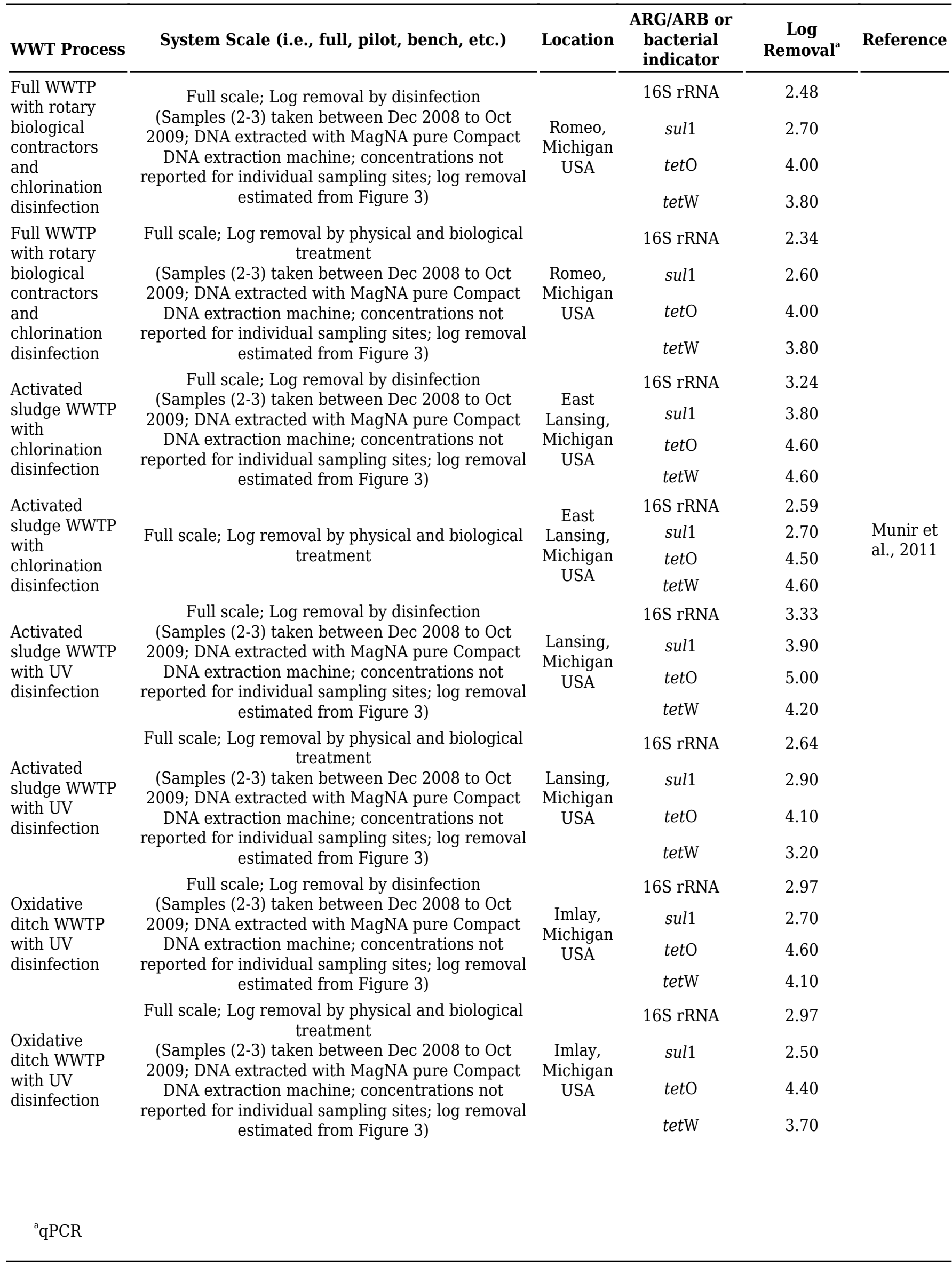




\section{References}

Abraham, W.R. (2011). Megacities as sources for pathogenic bacteria in rivers and their fate downstream. International Journal of Microbiology. 2010/10/05 ed.2011, pp. doi:10.1155/2011/798292.

Aertsen, A. and Michiels, C.W. (2006). Upstream of the SOS response: figure out the trigger. Trends in Microbiology. 14, pp. 421-423.

Aertsen, A., Van Houdt, R., Vanoirbeek, K. and Michiels, C.W. (2004). An SOS response induced by high pressure in Escherichia coli. Journal of Bacteriology. 186, pp. 6133-6141.

Agga, G.E., Arthur, T.M., Durso, L.M., Harhay, D.M. and Schmidt, J.W. (2015). Antimicrobial-Resistant Bacterial Populations and Antimicrobial Resistance Genes Obtained from Environments Impacted by Livestock and Municipal Waste. PLoS One.

Ahammad, Z.S., Sreekrishnan, T.R., Hands, C.L., Knapp, C.W. and Graham, D.W. (2014). Increased Waterborne bla(NDM-1) Resistance Gene Abundances Associated with Seasonal Human Pilgrimages to the Upper Ganges River. Environmental Science and Technology. 48, pp. 3014-3020.

Akiyama, T., Asfahl, K.L. and Savin, M.C. (2010). Broad-Host-Range Plasmids in Treated Wastewater Effluent and Receiving Streams. Journal of Environmental Quality. 39, pp. 2211-2215.

Al-Jassim, N., Ansari, M.I., Harb, M. and Hong, P.Y. (2015). Removal of bacterial contaminants and antibiotic resistance genes by conventional wastewater treatment processes in Saudi Arabia: Is the treated wastewater safe to reuse for agricultural irrigation?. Water Research. 73C, pp. 277-290.

Al-Tawfig, J.A., Laxminarayin, R. and Mendelson, M. (2017). How should we respond to the emergence of plasmid-mediated colistin resistance in humans and animals?. International Journal of Infectious Disease. pp. 77-84.

Alexander, J., Knopp, G., Dotsch, A., Wieland, A. and Schwartz, T. (2016). Ozone treatment of conditioned wastewater selects antibiotic resistance genes, opportunistic bacteria, and induce strong population shifts. Science of the Total Environment. 559, pp. 103-112.

Amos, G.C., Gozzard, E., Carter, C.E., Mead, A., Bowes, M.J., Hawkey, P.M. et al. (2015). Validated predictive modelling of the environmental resistome. The ISME Journal. 9, pp. 1467-76.

Anand, T., Bera, B.C., Vaid, R.K., Barua, S., Riyesh, T., Virmani, N. et al. (2016). Abundance of antibiotic resistance genes in environmental bacteriophages. Journal of General Virology. 97, pp. 3458-3466.

Andam, C.P. and Gogarten, J.P. (2011). Biased gene transfer in microbial evolution. Nature Reviews Microbiology. 2011/06/15 ed.9, pp. 543-55.

Andersson, D.I. and Hughes, D. (2014). Microbiological effects of sublethal levels of antibiotics. Nature Reviews Microbiology. 12, pp. 465-78.

Arango-Argoty, G., Garner, E., Pruden, A., Heath, L.S., Vikesland, P. and Zhang, L. (2018). DeepARG: A deep learning approach for predicting antibiotic resistance genes from metagenomic data. Microbiome. 6, pp. 23.

Ashbolt, N.J., Amézquita, A., Backhaus, T., Borriello, S.P., Brandt, K., Collignon, P. et al. (2013). Human health risk assessment (HHRA) for environmental development and transfer of antibiotic resistance. Environmental Health Perspectives. 121, pp. 993-1001.

Ashbolt, N.J., Grabow, W.O.K. and Snozzi, M. (2001). Indicators of microbial water quality. Water Quality - Guidelines, Standards and Health: Assessment of risk and risk management for water-related infectious disease. International Water Association Publishing. Cornwall, UK. 
Aubertheau, E., Stalder, T., Mondamert, L., Ploy, M.C., Dagot, C. and Labanowski, J. (2017). Impact of wastewater treatment plant discharge on the contamination of river biofilms by pharmaceuticals and antibiotic resistance. Science of the Total Environment. 579, pp. 1387-1398.

Auerbach, E.A., Seyfried, E.E. and McMahon, K.D. (2007). Tetracycline resistance genes in activated sludge wastewater treatment plants. Water Research. 41, pp. 1143-1151.

Börjesson, S., Melin, S., Matussek, A. and Lindgren, P.E. (2009). A seasonal study of the mecA gene and Staphylococcus aureus including methicillin-resistant S. aureus in a municipal wastewater treatment plant. Water research. 43, pp. 925-932.

Baharoglu, Z., Krin, E. and Mazel, D. (2012). Connecting Environment and Genome Plasticity in the Characterization of Transformation-Induced SOS Regulation and Carbon Catabolite Control of the Vibrio cholerae Integron Integrase. Journal of Bacteriology. 194, pp. 1659-1667.

Baharoglu, Z., Garriss, G. and Mazel, D. (2013). Multiple pathways of genome plasticity leading to development of antibiotic resistance. Journal of Antibiotics. 2, pp. 288-315.

Bartram, J., Cotruvo, J., Exner, M., Fricker, C. and Glasmacher, A. (2004). Heterotrophic plate count measurement in drinking water safety management - Report of an Expert Meeting Geneva, 24-25 April 2002. International Journal of Food Microbiology. 92, pp. 241-247.

Bauer, A.W., Kirby, W.M.M., Sherris, J.C. and Turck, M. (1966). Antibiotic susceptibility testing by a standardized single disk method. American Journal of Clinical Pathology. 45, pp. 493-496.

Beaber, J.W., Hochhut, B. and Waldor, M.K. (2004). SOS response promotes horizontal dissemination of antibiotic resistance genes. Nature. 427, pp. $72-74$

Beneragama, N., Iwasaki, M., Lateef, S.A., Yamashiro, T., Ihara, I. and Umetsu, K. (2013). Survival of multidrug-resistant bacteria in thermophilic and mesophilic anaerobic co-digestion of dairy manure and waste milk. Animal Science Journal. 84, pp. 426-33.

Bengtsson-Palme, J., Hammaren, R., Pal, C., Ostman, M., Bjorlenius, B., Flach, C.F. et al. (2016). Elucidating selection processes for antibiotic resistance in sewage treatment plants using metagenomics. Science of the Total Environment. 572, pp. 697-712.

Bengtsson-Palme, J., Larsson, D.G.J. and Kristiansson, E. (2017). Using metagenomics to investigate human and environmental resistomes. Journal of Antimicrobial Chemotherapy. 72, pp. 2690-2703.

Bengtsson-Palme, J., Rosenblad, M.A., Molin, M. and Blomberg, A. (2014). Metagenomics reveals that detoxification systems are underrepresented in marine bacterial communities. BMC Genomics.

Ben Said, L., Klibi, N., Lozano, C., Dziri, R., Ben Slama, K., Boudabous, A. et al. (2015). Diversity of enterococcal species and characterization of high-level aminoglycoside resistant enterococci of samples of wastewater and surface water in Tunisia. Science of the Total Environment. 530-531C, pp. 11-17.

Berendonk, T.U., Manaia, C.M., Merlin, C., Fatta-Kassinos, D., Cytryn, E., Walsh, F. et al. (2015). Tackling antibiotic resistance: the environmental framework. Nature Reviews Microbiology. 13, pp. 310-317.

Bernier, S.P., Lebeaux, D., DeFrancesco, A.S., Valomon, A., Soubigou, G., Coppee, J.Y. et al. (2013). Starvation, Together with the SOS Response, Mediates High Biofilm-Specific Tolerance to the Fluoroquinolone Ofloxacin. PloS Genetics.

Bischel, H.N., Duygan, B.D.Ozel, Strande, L., McArdell, C.S., Udert, K.M. and Kohn, T. (2015). Pathogens and pharmaceuticals in source-separated urine in eThekwini, South Africa. Water Research. 85, pp. 57-65.

Blaak, H., Lynch, G., Italiaander, R., Hamidjaja, R.A., Schets, F.M. and De Roda Husman, A.M. (2015). Multidrug-resistant and extended spectrum beta-lactamase-producing Escherichia coli in Dutch surface water and wastewater. PLoS One. 10, pp. e0127752. 
Blaak, H., van Hoek, A.H., Hamidjaja, R.A., van der Plaats, R.Q., L. de Heer, K.-., De Roda Husman, A.M. et al. (2015). Distribution, numbers, and diversity of ESBL-producing E. coli in the poultry farm environment. PLoS One. 10, pp. e0135402.

Bondarczuk, K., Markowicz, A. and Piotrowska-Seget, Z. (2016). The urgent need for risk assessment on the antibiotic resistance spread via sewage sludge land application. Environment International. 87, pp. 49-55.

Borjesson, S., Mattsson, A. and Lindgren, P.E. (2010). Genes encoding tetracycline resistance in a full-scale municipal wastewater treatment plant investigated during one year. Journal of Water and Health. 8, pp. 247-256.

Bouki, C., Venieri, D. and Diamadopoulos, E. (2013). Detection and fate of antibiotic resistant bacteria in wastewater treatment plants: a review. Ecotoxicology and Environmental Safety. 2013/02/19 ed.91, pp. 1-9.

Burch, T.R., Sadowsky, M.J. and LaPara, T.M. (2014). Fate of Antibiotic Resistance Genes and Class 1 Integrons in Soil Microcosms Following the Application of Treated Residual Municipal Wastewater Solids. Environmental Science and Technology. 48, pp. 5620-5627.

Burch, T.R., Sadowsky, M.J. and LaPara, T.M. (2013). Air-drying beds reduce the quantities of antibiotic resistance genes and class 1 integrons in residual municipal wastewater solids. Environmental science and technology. 47, pp. 9965-9971.

Burch, T.R., Sadowsky, M.J. and LaPara, T.M. (2013). Aerobic digestion reduces the quantity of antibiotic resistance genes in residual municipal wastewater solids. Frontiers in microbiology. 4, pp. 17.

Burch, T.R., Spencer, S.K., Stokdyk, J.P., Jr, B.A.Kieke, Larson, R.A., Firnstahl, A.D. et al. (2017). Quantitative microbial risk assessment for spray irrigation of dairy manure based on an empirical fate and transport model. Environmental Health Perspectives. 125, pp. 087009.

Cai, L. and Zhang, T. (2013). Detecting Human Bacterial Pathogens in Wastewater Treatment Plants by a High-Throughput Shotgun Sequencing Technique. Environmental Science and Technology. 47, pp. 5433-5441.

Calero-Cáceres, W. and Muniesa, M. (2016). Persistence of naturally occurring antibiotic resistance genes in the bacteria and bacteriophage fractions of wastewater. Water Research. 95, pp. 11-18.

Cantas, L., Shah, S.Q., Cavaco, L.M., Manaia, C.M., Walsh, F., Popowska, M. et al. (2013). A brief multi-disciplinary review on antimicrobial resistance in medicine and its linkage to the global environmental microbiota. Frontiers in Microbiology. 2013/05/16 ed.4, pp. 96.

Chang, C.Y., Lin, H.J., Chang, L.L., Ma, L., Siu, L.K., Tung, Y.C. et al. (2016). Characterization of extended-spectrum betalactamase-carrying plasmids in clinical isolates of Klebsiella pneumoniae from Taiwan. Microbial Drug Resistance.

Chee-Sanford, J.C., Mackie, R.I., Koike, S., Krapac, I.G., Lin, Y.F., Yannarell, A.C. et al. (2009). Fate and Transport of Antibiotic Residues and Antibiotic Resistance Genes following Land Application of Manure Waste. Journal of Environmental Quality. 38, pp. 1086-1108.

Chen, H. and Zhang, M.M. (2013). Effects of Advanced Treatment Systems on the Removal of Antibiotic Resistance Genes in Wastewater Treatment Plants from Hangzhou, China. Environmental Science and Technology. 47, pp. 8157-8163.

Chen, J., Ying, G.G., Wei, X.D., Liu, Y.S., Liu, S.S., Hu, L.X. et al. (2016). Removal of antibiotics and antibiotic resistance genes from domestic sewage by constructed wetlands: Effect of flow configuration and plant species. Science of the Total Environment. 571, pp. 974-82.

Christgen, B., Yang, Y., Ahammad, S.Z., Li, B., Rodriquez, D.C., Zhang, T. et al. (2015). Metagenomics shows that lowenergy anaerobic-aerobic treatment reactors reduce antibiotic resistance gene levels from domestic wastewater. Environmental Science and Technology. 49, pp. 2577-84.

CLSI (2015). Performance Standards for Antimicrobial Susceptibility Testing. 
Cox, G. and Wright, G.D. (2013). Intrinsic antibiotic resistance: Mechanisms, origins, challenges and solutions. International Journal of Medical Microbiology. 303, pp. 287-292.

Culyba, M.J., Mo, C.Y. and Kohli, R.M. (2015). Targets for Combating the Evolution of Acquired Antibiotic Resistance. Biochemistry. 54, pp. 3573-82.

Cummings, D.E., Archer, K.F., Arriola, D.J., Baker, P.A., Faucett, K.G., Laroya, J.B. et al. (2011). Broad dissemination of plasmid-mediated quinolone resistance genes in sediments of two urban coastal wetlands. Environmental Science and Technology. 2010/12/15 ed.45, pp. 447-54.

Czekalski, N., Berthold, T., Caucci, S., Egli, A. and Bürgmann, H. (2012). Increased levels of multiresistant bacteria and resistance genes after wastewater treatment and their dissemination into Lake Geneva, Switzerland. Frontiers in Microbiology. 3, pp. 106.

Davies, J.E. (2006). Aminoglycosides: Ancient and modern. Journal of Antibiotics. 59, pp. 529-532.

Di Cesare, A., Eckert, E.M., D'Urso, S., Bertoni, R., Gillan, D.C., Wattiez, R. et al. (2016). Co-occurrence of integrase 1, antibiotic and heavy metal resistance genes in municipal wastewater treatment plants. Water Research. 94, pp. 208-214.

Ding, C., Pan, J., Jin, M., Yang, D., Shen, Z., Wang, J. et al. (2016). Enhanced uptake of antibiotic resistance genes in the presence of nanoalumina. Nanotoxicology. 10, pp. 1051-60.

Done, H.Y. and Halden, R.U. (2015). Reconnaissance of 47 antibiotics and associated microbial risks in seafood sold in the United States. Journal of hazardous materialsJournal of hazardous materials. 282, pp. 10-17.

Dropa, M., Lincopan, N., Balsalobre, L.C., Oliveira, D.E., Moura, R.A., Fernandes, M.R. et al. (2016). Genetic background of novel sequence types of CTX-M-8-and CTX-M-15-producing Escherichia coli and Klebsiella pneumoniae from public wastewater treatment plants in Sao Paulo, Brazil. Environmental Science and Pollution ResearchEnvironmental Science and Pollution Research. 23, pp. 4953-4958.

Du, J., Ren, H., Geng, J., Zhang, Y., Xu, K. and Ding, L. (2015). Variation of antibiotic resistance genes in municipal wastewater treatment plant with A(2)O-MBR system. Environmental Science and pollution research. 22, pp. 3715-3726.

Du, J., Ren, H., Geng, J., Zhang, Y., Xu, K. and Ding, L. (2014). Occurrence and abundance of tetracycline, sulfonamide resistance genes, and class 1 integron in five wastewater treatment plants. Environmental Science and Pollution Research. 21, pp. 7276-7284.

EFSA (2017). ECDC/EFSA/EMA second joint report on the integrated analysis of the consumption of antimicrobial agents and occurrence of antimicrobial resistance in bacteria from humans and food-producing animals. 15, EFSA Journal. pp. $4872-5007$.

Ejrnaes, K. (2011). Bacterial characteristics of importance for recurrent urinary tract infections caused by Escherichia coli. Danish Medical Journal. 58, pp. B4187.

Enault, F., Briet, A., Bouteille, L., Roux, S., Sullivan, M.B. and Petit, M.A. (2017). Phages rarely encode antibiotic resistance genes: a cautionary tale for virome analyses. The ISME Journal. 11, pp. 237-247.

Engelstadter, J., Harms, K. and Johnsen, P.J. (2016). The evolutionary dynamics of integrons in changing environments. The ISME Journal. 10, pp. 1296-1307.

Fahrenfeld, N., Knowlton, K., Krometis, L.A., Hession, W.C., Xia, K., Lipscomb, E. et al. (2014). Effect of manure application on abundance of antibiotic resistance genes and their attenuation rates in soil: field-scale mass balance approach. Environmental Science and Technology. 48, pp. 2643-50.

Fang, H., Zhang, Q., Nie, X., Chen, B., Xiao, Y., Zhou, Q. et al. (2017). Occurrence and elimination of antibiotic resistance genes in a long-term operation integrated surface flow constructed wetland. Chemosphere. 173, pp. 99-106.

Fidjeland, J., Svensson, S.E. and Vinneras, B. (2015). Ammonia sanitization of blackwater for safe use as fertilizer. Water 
Science and Technology. 71, pp. 795-800.

Folster, J.P., Grass, J.E., Bicknese, A., Taylor, J., Friedman, C.R. and Whichard, J.M. (2016). Characterization of resistance genes and plasmids from outbreaks and illness clusters caused by Salmonella resistant to ceftriaxone in the United States, 2011-2012. Microbial Drug Resistance.

Forsberg, K.J., Reyes, A., Wang, B., Selleck, E.M., Sommer, M.O.A. and Dantas, G. (2012). The Shared Antibiotic Resistome of Soil Bacteria and Human Pathogens. ScienceScience. 337, pp. 1107-1111.

Gao, P., He, S., Huang, S., Li, K., Liu, Z., Xue, G. et al. (2015). Impacts of coexisting antibiotics, antibacterial residues, and heavy metals on the occurrence of erythromycin resistance genes in urban wastewater. Applied microbiology and biotechnologyApplied microbiology and biotechnology. 99, pp. 3971-3980.

Gao, P., Munir, M. and Xagoraraki, I. (2012). Correlation of tetracycline and sulfonamide antibiotics with corresponding resistance genes and resistant bacteria in a conventional municipal wastewater treatment plant. Science of the Total EnvironmentScience of the Total Environment. 421, pp. 173-183.

Garner, E., Wallace, J.S., Argoty, G.A., Wilkinson, C., Fahrenfeld, N., Heath, L.S. et al. (2016). Metagenomic profiling of historic Colorado Front Range flood impact on distribution of riverine antibiotic resistance genes. Scientific Reports.

Garner, M.J., Carson, C., Lingohr, E.J., Fazil, A., Edge, V.L. and Waddell, J.T. (2015). An Assessment of Antimicrobial Resistant Disease Threats in Canada. PLoS OnePLoS One.

Gaze, W.H., Zhang, L., Abdouslam, N.A., Hawkey, P.M., Calvo-Bado, L., Royle, J. et al. (2011). Impacts of anthropogenic activity on the ecology of class 1 integrons and integron-associated genes in the environment. Isme JournalIsme Journal. 5, pp. 1253-1261.

Gillings, M.R. (2014). Integrons: Past, Present, and Future. Microbiology and Molecular Biology ReviewsMicrobiology and Molecular Biology Reviews. 78, pp. 257-277.

Gillings, M.R., Gaze, W.H., Pruden, A., Smalla, K., Tiedje, J.M. and Zhu, Y.G. (2015). Using the class 1 integron-integrase gene as a proxy for anthropogenic pollution. Isme JournalIsme Journal. 9, pp. 1269-1279.

Giraud, E., Rychlik, I. and Cloeckaert, A. (2017). Antimicrobial resistance and virulence common mechanisms. Frontiers in microbiologyFrontiers in microbiology. 8, pp. 310.

Gondim-Porto, C., Platero, L., Nadal, I. and Navarro-Garcia, F. (2016). Fate of classical faecal bacterial markers and ampicillin-resistant bacteria in agricultural soils under Mediterranean climate after urban sludge amendment. Science of the Total EnvironmentScience of the Total Environment. 565, pp. 200-210.

Graham, D.W., Knapp, C.W., Christensen, B.T., McCluskey, S. and Dolfing, J. (2016). Appearance of beta-lactam Resistance Genes in Agricultural Soils and Clinical Isolates over the 20th Century. Scientific Reports.

Graham, D.W., Collignon, P., Davies, J., Larsson, D.G.Joakim and Snape, J. (2014). Underappreciated Role of Regionally Poor Water Quality on Globally Increasing Antibiotic Resistance. Environmental Science \&amp; TechnologyEnvironmental Science \&amp; Technology. 48, pp. 11746-11747.

Grenni, P., Ancona, V. and Caracciolo, A.Barra (2018). Ecological effects of antibiotics on natural ecosystems: A review. Microchemical JournalMicrochemical Journal. 136, pp. 25-39.

Guerin, E., Cambray, G., Sanchez-Alberola, N., Campoy, S., Erill, I., Da Re, S. et al. (2009). The SOS Response Controls Integron Recombination. ScienceScience. 324, pp. 1034-1034.

Guo, M.T., Yuan, Q.B. and Yang, J. (2015). Distinguishing effects of ultraviolet exposure and chlorination on the horizontal transfer of antibiotic resistance genes in municipal wastewater. Environmental Science and Technology. 49, pp. 5771-8.

Gupta, S.K., Padmanabhan, B.R., Diene, S.M., Lopez-Rojas, R., Kempf, M., Landraud, L. et al. (2014). ARG-ANNOT, a New Bioinformatic Tool To Discover Antibiotic Resistance Genes in Bacterial Genomes. Antimicrobial Agents and 
ChemotherapyAntimicrobial Agents and Chemotherapy. 58, pp. 212-220.

Höglund, C., Stenström, T.A. and Ashbolt, N. (2002). Microbial risk assessment of source-separated urine used in agriculture. Waste Management and Research. 20, pp. 150-161.

Hölzel, C.S., Harms, K.S., Bauer, J., Bauer-Unkauf, I., Hörmansdorfer, S., Kämpf, P. et al. (2012). Diversity of antimicrobial resistance genes and class-1-integrons in phylogenetically related porcine and human Escherichia coli. Veterinary Microbiology. 2012/08/03 ed.160, pp. 403-12.

Hocquet, D., Muller, A. and Bertrand, X. (2016). What happens in hospitals does not stay in hospitals: antibiotic-resistant bacteria in hospital wastewater systems. Journal of Hospital Infection. 93, pp. 395-402.

Holman, D.B., Hao, X., Topp, E., Yang, H.E. and Alexander, T.W. (2016). Effect of co-composting cattle manure with construction and demolition waste on the archaeal, bacterial, and fungal microbiota, and on antimicrobial resistance determinants. PLoS One. 11, pp. e0157539.

Huang, H., Zheng, X., Chen, Y., Liu, H., Wan, R. and Su, Y. (2016). Alkaline fermentation of waste sludge causes a significant reduction of antibiotic resistance genes in anaerobic reactors. Science of the Total Environment.

Huang, X., Liu, C., Li, K., Su, J., Zhu, G. and Liu, L. (2015). Performance of vertical up-flow constructed wetlands on swine wastewater containing tetracyclines and tet genes. Water Research. 70, pp. 109-17.

Hu, H.W., Wang, J.T., Li, J., Shi, X.Z., Ma, Y.B., Chen, D.L. et al. (2017). Long-Term Nickel Contamination Increases the Occurrence of Antibiotic Resistance Genes in Agricultural Soils. Environmental Science and Technology. 51, pp. 790-800.

Hu, Q., Zhang, X.X., Jia, S.Y., Huang, K.L., Tang, J.Y., Shi, P. et al. (2016). Metagenomic insights into ultraviolet disinfection effects on antibiotic resistome in biologically treated wastewater. Water Research. 101, pp. 309-317.

Jaatinen, S.T., Palmroth, M.R., Rintala, J.A. and Tuhkanen, T.A. (2016). The effect of urine storage on antiviral and antibiotic compounds in the liquid phase of source-separated urine. Environmental Technology. 37, pp. $2189-98$.

Jacobs, L. and Chenia, H.Y. (2007). Characterization of integrons and tetracycline resistance determinants in Aeromonas spp. isolated from South African aquaculture systems. International Journal of Food Microbiology. 114, pp. 295-306.

Jain, A. and Srivastava, P. (2013). Broad host range plasmids. FEMS Microbiology Letters. 348, pp. 87-96.

Janezic, S., Potocnik, M., Zidaric, V. and Rupnik, M. (2016). Highly Divergent Clostridium difficile Strains Isolated from the Environment. PLoS One.

Jia, B., Raphenya, A.R., Alcock, B., Waglechner, N., Guo, P., Tsang, K.K. et al. (2017). CARD 2017: expansion and modelcentric curation of the comprehensive antibiotic resistance database. Nucleic Acids Research. 45, pp. D566-D573.

Ju, F. and Zhang, T. (2015). Experimental Design and Bioinformatics Analysis for the Application of Metagenomics in Environmental Sciences and Biotechnology. Environmental Science and Technology. 49, pp. 12628-12640.

Kalmokoff, M., Waddington, L.M., Thomas, M., Liang, K.L., Ma, C., Topp, E. et al. (2011). Continuous feeding of antimicrobial growth promoters to commercial swine during the growing/finishing phase does not modify faecal community erythromycin resistance or community structure. Journal of Applied Microbiology. 2011/03/15 ed.110, pp. 1414-25.

Karkman, A., Johnson, T.A., Lyra, C., Stedtfeld, R.D., Tamminen, M., Tiedje, J.M. et al. (2016). High-throughput quantification of antibiotic resistance genes from an urban wastewater treatment plant. FEMS Microbiology Ecology.

Keen, E.C., Bliskovsky, V.V., Malagon, F., Baker, J.D., Prince, J.S., Klaus, J.S. et al. (2017). Novel "Superspreader" Bacteriophages Promote Horizontal Gene Transfer by Transformation. MBio.

KM, K., S, R., M, H., RE, M.L., DJ, B., SK, B. et al. (2016). Multiyear, multinational survey of the incidence and global distribution of metallo-beta-lactamase-producing Enterobacteriaceae and Pseudomonas aeruginosa. Antimicrobial Agents and Chemotherapy. pp. 1067-1078. 
Kotlarska, E., Luczkiewicz, A., Pisowacka, M. and Burzynski, A. (2015). Antibiotic resistance and prevalence of class 1 and 2 integrons in Escherichia coli isolated from two wastewater treatment plants, and their receiving waters (Gulf of Gdansk, Baltic Sea, Poland). Environmental Science and Pollution Research International. 22, pp. 2018-30.

Lüddeke, F., Heß, S., Gallert, C., Winter, J., Güde, H. and Löffler, H. (2015). Removal of total and antibiotic resistant bacteria in advanced wastewater treatment by ozonation in combination with different filtering techniques. Water Research. 69, pp. 243-251.

Lakin, S.M., Dean, C., Noyes, N.R., Dettenwanger, A., Ross, A.S., Doster, E. et al. (2017). MEGARes: an antimicrobial resistance database for high throughput sequencing. Nucleic Acids Research. 45, pp. D574-D580.

Larson, C.J. (2015). China's lakes of pig manure spawn antibiotic resistance. Science. 347, pp. 704.

Lawson, P.A., Citron, D.M., Tyrrell, K.L. and Finegold, S.M. (2016). Reclassification of Clostridium difficile as Clostridioides difficile (Hall and O'Toole 1935) Prevot 1938. Anaerobe. 40, pp. 95-99.

Layton, J.C. and Foster, P.L. (2005). Error-prone DNA polymerase IV is regulated by the heat shock chaperone GroE in Escherichia coli. Journal of Bacteriology. 187, pp. 449-457.

Levy, S.B. and Marshall, B. (2004). Antibacterial resistance worldwide: causes, challenges and responses. Nature Medicine. 10, pp. S122-S129.

Li, A.D., Li, L.G. and Zhang, T. (2015). Exploring antibiotic resistance genes and metal resistance genes in plasmid metagenomes from wastewater treatment plants. Frontiers in Microbiology.

Li, A.D., Li, L.G. and Zhang, T. (2015). Exploring antibiotic resistance genes and metal resistance genes in plasmid metagenomes from wastewater treatment plants. Frontiers in Microbiology.

Liakopoulos, A., Mevius, D.J., Olsen, B. and Bonnedahl, J. (2016). The colistin resistance mcr-1 gene is going wild. Journal of Antimicrobial Chemotherapy.

Liang, L., Goh, S.G., Vergara, G.G., Fang, H.M., Rezaeinejad, S., Chang, S.Y. et al. (2015). Alternative Fecal Indicators and Their Empirical Relationships with Enteric Viruses, Salmonella enterica, and Pseudomonas aeruginosa in Surface Waters of a Tropical Urban Catchment. Applied and Environmental Microbiology. 81, pp. 850-860.

Li, J., Cheng, W., Xu, L., Jiao, Y., Baig, S.A. and Chen, H. (2016). Occurrence and removal of antibiotics and the corresponding resistance genes in wastewater treatment plants: effluents' influence to downstream water environment. Environmental Science and Pollution Research. 23, pp. 6826-6835.

Li, N., Sheng, G.-.P., Lu, Y.-.Z., Zeng, R.J. and Yu, H.-.Q. (2017). Removal of antibiotic resistance genes from wastewater treatment plant effluent by coagulation. Water Research. 111, pp. 204-212.

Lin, W., Li, S., ZHANG, S. and Yu, X. (2016). Reduction in horizontal transfer of conjugative plasmid by UV irradiation and low-level chlorination. Water Research. 91, pp. 331-338.

Lin, W., Zhang, M., Zhang, S. and Yu, X. (2016). Can chlorination co-select antibiotic-resistance genes?. Chemosphere. 156, pp. 412-9.

Liu, B. and Pop, M. (2009). ARDB-Antibiotic Resistance Genes Database. Nucleic Acids Research. 37, pp. D443-D447.

Luby, E., A. Ibekwe, M., Zilles, J. and Pruden, A. (2016). Molecular Methods for Assessment of Antibiotic Resistance in Agricultural Ecosystems: Prospects and Challenges. Journal of Environmental Quality. 45, pp. 441-453.

Luo, Y., Yang, F., Mathieu, J., Mao, D., Wang, Q. and Alvarez, P.J.J. (2013). Proliferation of multidrug-resistant New Delhi metallo- $\beta$-lactamase genes in municipal wastewater treatment plants in northern China. Environmental Science and Technology Letters. 1, pp. 26-30.

Makowska, N., Koczura, R. and Mokracka, J. (2016). Class 1 integrase, sulfonamide and tetracycline resistance genes in 
wastewater treatment plant and surface water. Chemosphere. 144, pp. 1665-1673.

Ma, L., Xia, Y., Li, B., Yang, Y., Li, L.G., Tiedje, J.M. et al. (2016). Metagenomic assembly reveals hosts of antibiotic resistance genes and the shared resistome in pig, chicken, and human feces. Environmental Science and Technology. 50, pp. 420-7.

Mao, D., Yu, S., Rysz, M., Luo, Y., Yang, F., Li, F. et al. (2015). Prevalence and proliferation of antibiotic resistance genes in two municipal wastewater treatment plants. Water research. 85, pp. 458-466.

Marshall, B.M. and Levy, S.B. (2011). Food animals and antimicrobials: impacts on human health. Clinical Microbiology Reviews. 24, pp. 718-33.

Martinez, J.L. (2008). Antibiotics and antibiotic resistance genes in natural environments. Science. 321, pp. 365-367.

Marti, R., Scott, A., Tien, Y.C., Murray, R., Sabourin, L., Zhang, Y. et al. (2013). Impact of manure fertilization on the abundance of antibiotic-resistant bacteria and frequency of detection of antibiotic resistance genes in soil and on vegetables at harvest. Applied and Environmental Microbiology. 79, pp. 5701-9.

Massow, A. and Ebner, P. (2013). Antimicrobial Resistance Trends in Denmark Following the Ban on Including Antimicrobials in Livestock Feeds. http://www.extension.purdue.edu/extmedia/ID/ID-420-W.pdf. Purdue Extension ID-420W. Purdue University.

Matheu, J., Aidara-Kane, A. and Andremont, A. (2017). The ESBL tricycle AMR surveillance project: A simple, one health approach to global surveillance. AMR Control, One Health.

Ma, Y.J., Metch, J.W., Yang, Y., Pruden, A. and Zhang, T. (2016). Shift in antibiotic resistance gene profiles associated with nanosilver during wastewater treatment. Fems Microbiology Ecology.

Ma, Y.J., Wilson, C.A., Novak, J.T., Riffat, R., Aynur, S., Murthy, S. et al. (2011). Effect of Various Sludge Digestion Conditions on Sulfonamide, Macrolide, and Tetracycline Resistance Genes and Class I Integrons. Environmental Science and Technology. 45, pp. 7855-7861.

McArthur, A.G., Waglechner, N., Nizam, F., Yan, A., Azad, M.A., Baylay, A.J. et al. (2013). The Comprehensive Antibiotic Resistance Database. Antimicrobial Agents and Chemotherapy. 57, pp. 3348-3357.

McCall, C.A., Bent, E., Jorgensen, T.S., Dunfield, K.E. and Habash, M.B. (2016). Metagenomic Comparison of Antibiotic Resistance Genes Associated with Liquid and Dewatered Biosolids. Journal of Environmental Quality. 45, pp. 463-470.

McKinney, C.W., Loftin, K.A., Meyer, M.T., Davis, J.G. and Pruden, A. (2010). tet and sul Antibiotic Resistance Genes in Livestock Lagoons of Various Operation Type, Configuration, and Antibiotic Occurrence. Environmental Science and Technology. 44, pp. 6102-6109.

McKinney, C.W. and Pruden, A. (2012). Ultraviolet Disinfection of Antibiotic Resistant Bacteria and Their Antibiotic Resistance Genes in Water and Wastewater. Environmental Science and Technology. 46, pp. 13393-13400.

McLain, J.E., Cytryn, E., Durso, L.M. and Young, S. (2016). Culture-based Methods for Detection of Antibiotic Resistance in Agroecosystems: Advantages, Challenges, and Gaps in Knowledge. Journal of Environmental Quality. 45, pp. 432-440.

Mediavilla, J.R., Patrawalla, A., Chen, L., Chavda, K.D., Mathema, B., Vinnard, C. et al. (2016). Colistin- and carbapenemresistant Escherichia coli harboring $m c r-1$ and blaNDM-5, causing a complicated urinary tract infection in a patient from the United States. MBio.

Miller, J.H., Novak, J.T., Knocke, W.R. and Pruden, A. (2014). Elevation of antibiotic resistance genes at cold temperatures: implications for winter storage of sludge and biosolids. Letters in Applied Microbiology. 59, pp. 587-593.

Miranda, C.D., Tello, A. and Keen, P.L. (2013). Mechanisms of antimicrobial resistance in finfish aquaculture environments. Frontiers in Microbiology. 4, pp. 233. 
Munck, C., Albertsen, M., Telke, A., Ellabaan, M., Nielsen, P.H. and Sommer, M.O.A. (2015). Limited dissemination of the wastewater treatment plant core resistome. Nature Communications.

Munir, M., Wong, K. and Xagoraraki, I. (2011). Release of antibiotic resistant bacteria and genes in the effluent and biosolids of five wastewater utilities in Michigan. Water Research. 2010/09/21 ed.45, pp. 681-93.

Munir, M., Wong, K. and Xagoraraki, I. (2011). Release of antibiotic resistant bacteria and genes in the effluent and biosolids of five wastewater utilities in Michigan. Water Research. 45, pp. 681-693.

Munk, P., Andersen, V.D., de Knegt, L., Jensen, M.S., Knudsen, B.E., Lukjancenko, O. et al. (2017). A sampling and metagenomic sequencing-based methodology for monitoring antimicrobial resistance in swine herds. Journal of Antimicrobial Chemotherapy. 72, pp. 385-392.

Narciso-da-Rocha, C. and Manaia, C.M. (2017). The influence of the autochthonous wastewater microbiota and gene host on the fate of invasive antibiotic resistance genes. Science of the Total Environment. 575, pp. 932-940.

Neudorf, K.D., Huang, Y.Nan, Ragush, C.M., Yost, C.K., Jamieson, R.C. and Hansen, L.Truelstrup (2017). Antibiotic resistance genes in municipal wastewater treatment systems and receiving waters in Arctic Canada. Science of the Total Environment. 598, pp. 1085-1094.

NORMAN (2017). Network of reference laboratories, research centres and related organisations for monitoring of emerging environmental substances.

O’Neill, J. (2016). The review on antimicrobial resistance. Tackling drug-resistant infections globally: final report and recommendations.

O'Neill, J. (2016). Review on Antimicrobial Resistance. Tackling drug-resistant infections globally. Welcome Trust and HM Government. London, England.

Office of the President (2015). National Action Plan for Combating Antibiotic-Resistant Bacteria.

Osińska, A., Korzeniewska, E., Harnisz, M. and Niestępski, S. (2017). The prevalence and characterization of antibioticresistant and virulent Escherichia coli strains in the municipal wastewater system and their environmental fate. Science of the Total Environment. 577, pp. 367-375.

Ovejero, C.M., Delgado-Blas, J.F., Calero-Cáceres, W., Muniesa, M. and Gonzalez-Zorn, B. (2017). Spread of mcr-1-carrying Enterobacteriaceae in sewage water from Spain. Journal of Antimicrobial Chemotherapy. 72, pp. 1050-1053.

Pak, G., Salcedo, D.E., Lee, H., Oh, J., Maeng, S.K., Song, K.G. et al. (2016). Comparison of Antibiotic Resistance Removal Efficiencies Using Ozone Disinfection under Different pH and Suspended Solids and Humic Substance Concentrations. Environmental Science and Technology. 50, pp. 7590-7600.

Pal, C., Bengtsson-Palme, J., Kristiansson, E. and Larsson, D.G. (2016). The structure and diversity of human, animal and environmental resistomes. Microbiome. 4, pp. 54.

Park, E., Mancl, K.M., Tuovinen, O.H., Bisesi, M.S. and Lee, J. (2016). Ensuring safe reuse of residential wastewater: reduction of microbes and genes using peat biofilter and batch chlorination in an on-site treatment system. Journal of Applied Microbiology. 121, pp. 1777-1788.

Pei, J., Yao, H., Wang, H., Ren, J. and Yu, X. (2016). Comparison of ozone and thermal hydrolysis combined with anaerobic digestion for municipal and pharmaceutical waste sludge with tetracycline resistance genes. Water Research. 99, pp. 122-128.

Petersen, T.N., Lukjancenko, O., Thomsen, M.C.F., Sperotto, M.M., Lund, O., Aarestrup, F.M. et al. (2017). MGmapper: Reference based mapping and taxonomy annotation of metagenomics sequence reads. PLoS One.

Poirel, L., Rodriguez-Martinez, J.M., Mammeri, H., Liard, A. and Nordmann, P. (2005). Origin of plasmid-mediated quinolone resistance determinant QnrA. Antimicrobial Agents and Chemotherapy. 49, pp. 3523-3525. 
Poole, K. (2012). Stress responses as determinants of antimicrobial resistance in Gram-negative bacteria. Trends in Microbiology. 20, pp. 227-234.

Port, J.A., Wallace, J.C., Griffith, W.C. and Faustman, E.M. (2012). Metagenomic Profiling of Microbial Composition and Antibiotic Resistance Determinants in Puget Sound. PLoS One.

Pruden, A., Arabi, M. and Storteboom, H.N. (2012). Correlation Between Upstream Human Activities and Riverine Antibiotic Resistance Genes. Environmental Science and Technology. 46, pp. 11541-11549.

Pruden, A., Larsson, D.G.Joakim, Amezquita, A., Collignon, P., Brandt, K.K., Graham, D.W. et al. (2013). Management options for reducing the release of antibiotics and antibiotic resistance genes to the environment. Environmental Health Perspectives. 121, pp. 878-885.

Pruden, A., Pei, R., Storteboom, H. and Carlson, K.H. (2006). Antibiotic resistance genes as emerging contaminants: studies in northern Colorado. Environmental Science and Technology. 40, pp. 7445-7450.

Pynnonen, S.T. and Tuhkanen, T.A. (2014). Simultaneous detection of three antiviral and four antibiotic compounds in source-separated urine with liquid chromatography. Journal of Separation Science. 37, pp. 219-27.

Quintela-Baluja, M., Chan, C.W., M. Alnakip, E., Abouelnaga, M. and Graham, D.W. (2015). Sanitation, water quality and antibiotic resistance dissemination. The Battle Against Microbial Pathogens: Basic Science, Technological Advances and Educational Programs. (Méndez-Vilas, A., ed.). Formatex Research Center. pp. 965-975.

Rafraf, I.Denden, Lekunberri, I., Sànchez-Melsió, A., Aouni, M., Borrego, C.M. and Balcazar, J.Luis (2016). Abundance of antibiotic resistance genes in five municipal wastewater treatment plants in the Monastir Governorate, Tunisia. Environmental Pollution. 219, pp. 353-358.

Rizzo, L., Manaia, C., Merlin, C., Schwartz, T., Dagot, C., Ploy, M.C. et al. (2013). Urban wastewater treatment plants as hotspots for antibiotic resistant bacteria and genes spread into the environment: a review. Science of the Total Environment. 447, pp. 345-360.

Rizzo, L., Fiorentino, A. and Anselmo, A. (2013). Advanced treatment of urban wastewater by UV radiation: Effect on antibiotics and antibiotic-resistant E. coli strains. Chemosphere. 92, pp. 171-6.

Rizzo, L., Manaia, C., Merlin, C., Schwartz, T., Dagot, C., Ploy, M.C. et al. (2013). Urban wastewater treatment plants as hotspots for antibiotic resistant bacteria and genes spread into the environment: a review. Science of the Total Environment. 447, pp. 345-60.

Rodriguez-Mozaz, S., Chamorro, S., Marti, E., Huerta, B., Gros, M., Sanchez-Melsio, A. et al. (2015). Occurrence of antibiotics and antibiotic resistance genes in hospital and urban wastewaters and their impact on the receiving river. Water Research. 69, pp. 234-42.

Ross, J. and Topp, E. (2015). Abundance of antibiotic resistance genes in bacteriophage following soil fertilization with dairy manure or municipal biosolids, and evidence for potential transduction. Applied and Environmental Microbiology. 81, pp. 7905-13.

Rothrock, Jr., M.J., Keen, P.L., Cook, K.L., Durso, L.M., Franklin, A.M. and Dungan, R.S. (2016). How Should We Be Determining Background and Baseline Antibiotic Resistance Levels in Agroecosystem Research?. Journal of Environmental Quality. 45, pp. 420-431.

Rowe, W., Verner-Jeffreys, D.W., Baker-Austin, C., Ryan, J.J., Maskell, D.J. and Pearce, G.P. (2016). Comparative metagenomics reveals a diverse range of antimicrobial resistance genes in effluents entering a river catchment. Water Science and Technology. 73, pp. 1541-1549.

Sacramento, A.G., Cerdeira, L.T., de Almeida, L.M., Zanella, R.C., Pires, C., Sato, M.I. et al. (2016). Environmental dissemination of vanA-containing Enterococcus faecium strains belonging to hospital-associated clonal lineages. Journal of Antimicrobial Chemotherapy. 71, pp. 264-266. 
Saito, S., Koori, Y., Ohsaki, Y., Osaka, S., Oana, K., Nagano, Y. et al. (2016). Third-generation cephalosporin-resistant nontyphoidal Salmonella isolated from human feces in Japan. Japanese Journal of Infectious Diseases.

Santoro, D.O., Cardoso, A.M., Coutinho, F.H., Pinto, L.H., Vieira, R.P., Albano, R.M. et al. (2015). Diversity and antibiotic resistance profiles of Pseudomonads from a hospital wastewater treatment plant. Journal of Applied Microbiology. 119, pp. 1527-1540.

Santos, D.F.K. dos, Istvan, P., Quirino, B.F. and Kruger, R.H. (2017). Functional Metagenomics as a Tool for Identification of New Antibiotic Resistance Genes from Natural Environments. Microbial Ecology. 73, pp. 479-491.

Schönning, C., Westrell, T., Stenström, T.A., Arnbjerg-Nielsen, K., Høibye, L. and Carlsen, A. (2007). Microbial risk assessment of local handling and reuse of human faeces. Journal of Water and Health. 5, pp. 117-128.

Schluter, A., Krause, L., Szczepanowski, R., Goesmann, A. and Puhler, A. (2008). Genetic diversity and composition of a plasmid metagenome from a wastewater treatment plant. Journal of Biotechnology. 136, pp. 65-76.

Schmidt, K., Mwaigwisya, S., Crossman, L.C., Doumith, M., Munroe, D., Pires, C. et al. (2017). Identification of bacterial pathogens and antimicrobial resistance directly from clinical urines by nanopore-based metagenomic sequencing. Journal of Antimicrobial Chemotherapy. 72, pp. 104-114.

Sharma, V.K., Johnson, N., Cizmas, L., McDonald, T.J. and Kim, H. (2016). A review of the influence of treatment strategies on antibiotic resistant bacteria and antibiotic resistance genes. Chemosphere. 150, pp. 702-14.

Sidrach-Cardona, R., Hijosa-Valsero, M., Marti, E., Balcazar, J.L. and Bécares, E. (2014). Prevalence of antibiotic-resistant fecal bacteria in a river impacted by both an antibiotic production plant and urban treated discharges. Science of the Total Environment. 488-489, pp. 220-7.

Singer, A.C., Shaw, H., Rhodes, V. and Hart, A. (2016). Review of antimicrobial resistance in the environment and its relevance to environmental regulators. Frontiers in Microbiology.

Singer, R.S., Ward, M.P. and Maldonado, G. (2006). Can landscape ecology untangle the complexity of antibiotic resistance?. Nature Reviews Microbiology. 4, pp. 943-52.

Songe, M., Hang'ombe, B., Knight-Jones, T. and Grace, D. (2017). Antimicrobial resistant enteropathogenic Escherichia coli and Salmonella spp. in houseflies infesting fish in food markets in Zambia. International Journal of Environmental Research and Public Health. 14, pp. 21.

Spanogiannopoulos, P., Waglechner, N., Koteva, K. and Wright, G.D. (2014). A rifamycin inactivating phosphotransferase family shared by environmental and pathogenic bacteria. Proceedings of the National Academy of Sciences of the United States of America. 111, pp. 7102-7.

Stalder, T., Barraud, O., Casellas, M., Dagot, C. and Ploy, M.C. (2012). Integron involvement in environmental spread of antibiotic resistance. Frontiers in Microbiology. 3, pp. 119.

Stalder, T., Barraud, O., Jove, T., Casellas, M., Gaschet, M., Dagot, C. et al. (2014). Quantitative and qualitative impact of hospital effluent on dissemination of the integron pool. The ISME Journal. 2013/10/25 ed.8, pp. 768-77.

Stanczak-Mrozek, K.I., Manne, A., Knight, G.M., Gould, K., Witney, A.A. and Lindsay, J.A. (2015). Within-host diversity of MRSA antimicrobial resistances. Journal of Antimicrobial Chemotherapy. 70, pp. 2191-8.

Stokes, H.W. and Gillings, M.R. (2011). Gene flow, mobile genetic elements and the recruitment of antibiotic resistance genes into Gram-negative pathogens. FEMS Microbiology Reviews. 2011/04/27 ed.35, pp. 790-819.

Storteboom, H., Arabi, M., Davis, J.G., Crimi, B. and Pruden, A. (2010). Identification of Antibiotic-Resistance-Gene Molecular Signatures Suitable as Tracers of Pristine River, Urban, and Agricultural Sources. Environmental Science and Technology. 44, pp. 1947-1953.

Sung, J.Y., Koo, S.H., Kim, S. and Kwon, K.C. (2014). Epidemiological Characterizations of Class 1 Integrons from 
Multidrug-Resistant Acinetobacter Isolates in Daejeon, Korea. Annals of Laboratory Medicine. 34, pp. $293-299$.

Surette, M.D. and Wright, G.D. (2017). Lessons from the Environmental Antibiotic Resistome. Annual Review of Microbiology, Vol 71. 71, (Gottesman, S., ed.). pp. 309-329.

Szczepanowski, R., Linke, B., Krahn, I., Gartemann, K.H., Gutzkow, T., Eichler, W. et al. (2009). Detection of 140 clinically relevant antibiotic-resistance genes in the plasmid metagenome of wastewater treatment plant bacteria showing reduced susceptibility to selected antibiotics. Microbiology. 2009/04/25 ed.155, pp. 2306-19.

Tang, J., Bu, Y., Zhang, X.-.X., Huang, K., He, X., Ye, L. et al. (2016). Metagenomic analysis of bacterial community composition and antibiotic resistance genes in a wastewater treatment plant and its receiving surface water. Ecotoxicology and environmental safety. 132, pp. 260-269.

Tao, C.W., Hsu, B.M., Ji, W.T., Hsu, T.K., Kao, P.M., Hsu, C.P. et al. (2014). Evaluation of five antibiotic resistance genes in wastewater treatment systems of swine farms by real-time PCR. Science of the Total Environment. 496, pp. 116-21.

Tao, W.D., Zhang, X.X., Zhao, F.Z., Huang, K.L., Ma, H.J., Wang, Z. et al. (2016). High Levels of Antibiotic Resistance Genes and Their Correlations with Bacterial Community and Mobile Genetic Elements in Pharmaceutical Wastewater Treatment Bioreactors. PLoS One.

Taylor, N.G., Verner-Jeffreys, D.W. and Baker-Austin, C. (2011). Aquatic systems: maintaining, mixing and mobilising antimicrobial resistance?. Trends in ecology and evolution. 2011/04/05 ed.26, pp. 278-84.

Tian, Z., Zhang, Y., Yu, B. and Yang, M. (2016). Changes of resistome, mobilome and potential hosts of antibiotic resistance genes during the transformation of anaerobic digestion from mesophilic to thermophilic. Water Research. 98, pp. 261-9.

Tilley, E. (2016). Cost-effectiveness and community impacts of two urine-collection programs in rural South Africa. Environmental Science: Water Research and Technology.

Varela, A.Rita, Nunes, O.C. and Manaia, C.M. (2016). Quinolone resistant Aeromonas spp. as carriers and potential tracers of acquired antibiotic resistance in hospital and municipal wastewater. Science of The Total Environment. 542, pp. $665-671$.

Vaz-Moreira, I., Varela, A.R., Pereira, T.V., Fochat, R.C. and Manaia, C.M. (2016). Multidrug Resistance in QuinoloneResistant Gram-Negative Bacteria Isolated from Hospital Effluent and the Municipal Wastewater Treatment Plant. Microbial Drug Resistance. 22, pp. 155-163.

von Wintersdorff, C.J., Penders, J., van Niekerk, J.M., Mills, N.D., Majumder, S., van Alphen, L.B. et al. (2016). Dissemination of antimicrobial resistance in microbial ecosystems through horizontal gene transfer. Frontiers in Microbiology. 7, pp. 173.

Walsh, T.R., Weeks, J., Livermore, D.M. and Toleman, M.A. (2011). Dissemination of NDM-1 positive bacteria in the New Delhi environment and its implications for human health: an environmental point prevalence study. The Lancet infectious diseases. 2011/04/12 ed.11, pp. 355-62.

Wang, Z., Zhang, X.X., Huang, K.L., Miao, Y., Shi, P., Liu, B. et al. (2013). Metagenomic Profiling of Antibiotic Resistance Genes and Mobile Genetic Elements in a Tannery Wastewater Treatment Plant. PLoS One.

Wen, Q., Yang, L., Duan, R. and Chen, Z. (2016). Monitoring and evaluation of antibiotic resistance genes in four municipal wastewater treatment plants in Harbin, Northeast China. Environmental Pollution. 212, pp. 34-40.

Westhoff, S., van Leeuwe, T.Marijn, Qachach, O., Zhang, Z., van Wezel, G.Philippus and Rozen, D.Eric (2017). The evolution of no-cost resistance at sub-MIC concentrations of streptomycin in Streptomyces coelicolor. The ISME Journal. 11, pp. 1168-1178.

WHO (2017). Global priority list of antibiotic-resistant bacteria to guide research, discovery, and development of new antibiotics. 
WHO (2016). Soil-trasnmitted helminth infections. Fact Sheet.

WHO (2015). Briefing Note. Antimicrobial Resistance: An Emerging Water, Sanitation and Hygiene Issue WHO/FWC/WSH/14.7. World Health Organization. Geneva. pp. 16.

WHO (2014). Antimicrobial Resistance Global Report on surveillance 2014. World Health Organization. Geneva.

Wichmann, F., Udikovic-Kolic, N., Andrew, S. and Handelsman, J. (2014). Diverse Antibiotic Resistance Genes in Dairy Cow Manure. MBio.

Xie, X.F., Zhang, H.F., Zheng, Y., Li, A.Q., Wang, M., Zhou, H.Q. et al. (2016). RpoE is a Putative Antibiotic Resistance Regulator of Salmonella enteric Serovar Typhi. Current Microbiology. 72, pp. 457-464.

$\mathrm{Xu}$, C., Wang, D., Huber, A., Weese, S.J. and Warriner, K. (2016). Persistence of Clostridium difficile in wastewater treatment-derived biosolids during land application or windrow composting. Journal of Applied Microbiology. 120, pp. 312-320.

Yang, Y., Li, B., Zou, S.C., Fang, H.H.P. and Zhang, T. (2014). Fate of antibiotic resistance genes in sewage treatment plant revealed by metagenomic approach. Water Research. 62, pp. 97-106.

Yang, Y., Jiang, X., Chai, B., Ma, L., Li, B., Zhang, A. et al. (2016). ARGs-OAP: online analysis pipeline for antibiotic resistance genes detection from metagenomic data using an integrated structured ARG-database. Bioinformatics. 32, pp. 2346-2351.

Yan, X., Luo, X.G. and Zhao, M. (2016). Metagenomic analysis of microbial community in uranium-contaminated soil. Applied Microbiology and Biotechnology. 100, pp. 299-310.

Youngquist, C.P., Mitchell, S.M. and Cogger, C.G. (2016). Fate of antibiotics and antibiotic resistance during digestion and composting: A review. Journal of Environment Quality. 45, pp. 537.

Zaiss, N.H., Witte, W. and Nubel, U. (2010). Fluoroquinolone Resistance and Clostridium difficile, Germany. Emerging Infectious Diseases. 16, pp. 675-677.

Zankari, E., Hasman, H., Cosentino, S., Vestergaard, M., Rasmussen, S., Lund, O. et al. (2012). Identification of acquired antimicrobial resistance genes. Journal of Antimicrobial Chemotherapy. 67, pp. 2640-2644.

Zankari, E., Hasman, H., Kaas, R.S., Seyfarth, A.M., Agerso, Y., Lund, O. et al. (2013). Genotyping using whole-genome sequencing is a realistic alternative to surveillance based on phenotypic antimicrobial susceptibility testing. Journal of Antimicrobial Chemotherapy. 68, pp. 771-777.

Zanotto, C., Bissa, M., Illiano, E., Mezzanotte, V., Marazzi, F., Turolla, A. et al. (2016). Identification of antibiotic-resistant Escherichia coli isolated from a municipal wastewater treatment plant. Chemosphere. 164, pp. 627-633.

Zhang, J., Sui, Q., Tong, J., Buhe, C., Wang, R., Chen, M. et al. (2016). Sludge bio-drying: Effective to reduce both antibiotic resistance genes and mobile genetic elements. Water Research. 106, pp. 62-70.

Zhang, R., Yang, Y., Huang, C.H., ZHAO, L. and Sun, P. (2016). Kinetics and modeling of sulfonamide antibiotic degradation in wastewater and human urine by UV/H2O2 and UV/PDS. Water Research. 103, pp. 283-92.

Zhang, T., Yang, Y. and Pruden, A. (2015). Effect of temperature on removal of antibiotic resistance genes by anaerobic digestion of activated sludge revealed by metagenomic approach. Applied microbiology and biotechnology. 99, pp. 7771-7779.

Zhang, T., Zhang, M., Zhang, X. and Fang, H.Hanping (2009). Tetracycline resistance genes and tetracycline resistant lactose-fermenting Enterobacteriaceae in activated sludge of sewage treatment plants. Environmental science and technology. 43, pp. 3455-3460.

Zhang, X., Wu, B., Zhang, Y., Zhang, T., Yang, L., Fang, H.H.P. et al. (2009). Class 1 integronase gene and tetracycline 
resistance genes tetA and tetC in different water environments of Jiangsu Province, China. Ecotoxicology. 18, pp. 652-660.

Zhang, Y., Zhuang, Y., Geng, J., Ren, H., Zhang, Y., Ding, L. et al. (2015). Inactivation of antibiotic resistance genes in municipal wastewater effluent by chlorination and sequential UV/chlorination disinfection. Science of the Total Environment. 512-513, pp. 125-32.

Zhang, Y., Gu, A.Z., He, M., Li, D. and Chen, J. (2017). Subinhibitory Concentrations of Disinfectants Promote the Horizontal Transfer of Multidrug Resistance Genes within and across Genera. Environmental Science and Technology. 51, pp. 570-580.

Zhu, Y.G., Zhao, Y., Li, B., Huang, C.L., Zhang, S.Y., Yu, S. et al. (2017). Continental-scale pollution of estuaries with antibiotic resistance genes. Nature Microbiology. 